VILNIUS GEDIMINAS TECHNICAL UNIVERSITY,

STATE RESEARCH INSTITUTE CENTER FOR PHYSICAL SCIENCES AND TECHNOLOGY

Martynas ŠAPUROV

\title{
DEVELOPMENT OF SMOOTH ASYMMETRIC REACTIVE POWER COMPENSATORS
}

DOCTORAL DISSERTATION

TECHNOLOGICAL SCIENCES,

ELECTRICAL AND ELECTRONIC ENGINEERING (T 001)

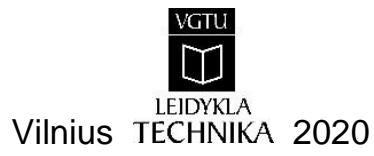


Doctoral dissertation was prepared at the State Research Institute Center for Physical Sciences and Technology in 2014-2020.

\section{Supervisor}

Prof. Dr Algirdas BAŠKYS (State Research Institute Center for Physical

Sciences and Technology, Electrical and Electronic Engineering - T 001).

The Dissertation Defence Council of Scientific Field of Electrical and Electronic Engineering of Vilnius Gediminas Technical University:

\section{Chairman}

Prof. Dr Dalius NAVAKAUSKAS (Vilnius Gediminas Technical University, Electrical and Electronic Engineering - T 001).

\section{Members:}

Assoc. Prof. Dr Saulius GUDŽIUS (Kaunas University of Technology, Electrical and Electronic Engineering - T 001),

Prof. Dr Jurij NOVICKIJ (Vilnius Gediminas Technical University, Electrical and Electronic Engineering - T 001),

Dr Iouliia SKLIAROVA (Aveiro University, Portugal, Electrical and Electronic Engineering - T 001),

Dr Česlovas ŠIMKEVIČIUS (State Research Institute Center for Physical Sciences and Technology, Electrical and Electronic Engineering - T 001).

The dissertation will be defended at the public meeting of the Dissertation Defence Council of Electrical and Electronic Engineering in the Senate Hall of Vilnius Gediminas Technical University at 2 p. m. on 28 September 2020.

Address: Saulètekio al. 11, LT-10223 Vilnius, Lithuania.

Tel.: +370 5274 4956; fax +370 5270 0112; e-mail: doktor@vgtu.lt

A notification on the intend defending of the dissertation was send on 27 August 2020.

A copy of the doctoral dissertation is available for review at VGTU repository http://dspace.vgtu.lt/ and at the Library of Vilnius Gediminas Technical University (Sauletekio al. 14, LT-10223 Vilnius, Lithuania) and at the Wroblewski Library of the Lithuanian Academy of Sciences (Žygimantų st. 1, LT-01102, Vilnius, Lithuania)

VGTU leidyklos TECHNIKA 2020-027-M mokslo literatūros knyga http://leidykla.vgtu.lt

(C) VGTU leidykla TECHNIKA, 2020

(C) Martynas Šapurov, 2020

martynas.sapurov@ftmc.lt 
VILNIUS GEDIMINO TECHNIKOS UNIVERSITETAS, VALSTYBINIS MOKSLINIŲ TYRIMUৃ INSTITUTAS

FIZINIŲ IR TECHNOLOGIJOS MOKSLŲ CENTRAS

Martynas ŠAPUROV

\section{TOLYDŽIỤJỤ ASIMETRINIŲ REAKTYVIOSIOS GALIOS KOMPENSATORIŲ KÜRIMAS}

DAKTARO DISERTACIJA

TECHNOLOGIJOS MOKSLAI,

ELEKTROS IR ELEKTRONIKOS INŽINERIJA (T 001)

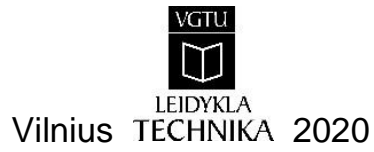


Disertacija rengta 2014-2020 metais Valstybiniame mokslinių tyrimų institute Fizinių ir technologijos mokslų centre.

\section{Vadovas}

prof. dr. Algirdas BAŠKYS (Valstybinis mokslinių tyrimų institutas Fizinių ir technologijos mokslų centras, elektros ir elektronikos inžinerija - T 001).

Vilniaus Gedimino technikos universiteto elektros iš elektronikos inžinerijos mokslo krypties disertacijos gynimo taryba:

\section{Pirmininkas}

prof. dr. Dalius NAVAKAUSKAS (Vilniaus Gedimino technikos universitetas, elektros ir elektronikos inžinerija - T 001).

\section{Nariai:}

doc. dr. Saulius GUDŽIUS (Kauno technologijos universitetas, elektros ir elektronikos inžinerija - T 001),

prof. dr. Jurij NOVICKIJ (Vilniaus Gedimino technikos universitetas, elektros ir elektronikos inžinerija - T 001),

dr. Iouliia SKLIAROVA (Aveiro universitetas, Portugalija, elektros ir elektronikos inžinerija - T 001),

dr. Česlovas ŠIMKEVIČIUS (Valstybinis mokslinių tyrimų institutas Fizinių ir technologijos mokslų centras, elektros ir elektronikos inžinerija - T 001).

Disertacija bus ginama viešame Elektros ir elektronikos inžinerijos mokslo krypties disertacijos gynimo tarybos posėdyje 2020 m. rugsẻjo $28 \mathrm{~d}$. 14 val. Vilniaus Gedimino technikos universiteto senato posèdžių salèje.

Adresas: Sauletekio al. 11, LT-10223 Vilnius, Lietuva.

Tel.: (8 5) 274 4956; faksas (8 5) 270 0112; el. paštas doktor@vgtu.lt

Pranešimai apie numatomą ginti disertaciją išsiųsti 2020 m. rugpjūčio 27 d.

Disertaciją galima peržiūrèti VGTU talpykloje http://dspace.vgtu.lt/ ir Vilniaus Gedimino technikos universiteto bibliotekoje (Saulètekio al. 14, LT-10223 Vilnius, Lietuva) ir Lietuvos mokslų akademijos Vrublevskių bibliotekoje (Žygimantų g. 1, LT-01102 Vilnius, Lietuva). 


\section{Abstract}

The aim of the performed research is development of reactive power compensators for the smooth and asymmetric reactive power compensation in the low voltage utility grid.

The cascaded inverter has been modified and adapted for the smooth compensation of reactive power. The topologies of the conventional and cascaded inverter-based reactive power compensators with the individual inverters for the every phase for the asymmetric compensation of reactive power have been proposed. The shunt-connected compensator for the smooth and asymmetric compensation of reactive power in the low voltage utility grid has been developed. The investigation of developed reactive power compensators was performed using simulation and experimentally.

The dissertation consists of an introduction, three chapters, general conclusions, references and the list of author's publications on the topic of the dissertation.

The research problem, the relevance of the work, the object of research are presented in the introductory chapter. The aim and objectives of the work, the research methodology, scientific novelty of the work, the practical significance of the work results, defended statements are presented as well. At the end of the introduction, the author's publications and conference papers on the topic of the dissertation and the structure of the dissertation are given.

The first chapter analyzes the reactive power compensation techniques and compensator types. The inverter-based reactive power compensators and shuntconnected reactive power compensators are analyzed. The conclusions are drawn out and the tasks of the dissertation are formulated.

The conventional and cascaded inverter-based reactive power compensators are analyzed in the second chapter. The topologies of reactive power compensators with the individual ordinary inverters and cascaded inverters for the every phase for the asymmetric compensation of reactive power are proposed. The Matlab/Simulink models of compensators were created and investigation of compensators using simulation was performed.

In the third chapter the developed shunt-connected compensator for smooth asymmetric compensation of reactive power in low voltage utility grid is presented. The investigation of compensator was performed experimentally using developed experimental test bench.

The main results of the dissertation have been published in 4 scientific publications -3 of them have been published in peer-reviewed scientific journals, 1 in conference proceedings. The results were presented at 5 scientific conferences. 


\section{Reziumè}

Tyrimo tikslas - sukurti reaktyviosios galios kompensatorius tolydžiam, asimetriniam reaktyviosios galios kompensavimui žemosios įtampos tinkle.

Kaskadinis inverteris buvo modifikuotas ir pritaikytas tolydžiam reaktyviosios galios kompensavimui. Siūlomos kompensatorių schemos su atskirais klasikiniu ir kaskadiniu inverteriais kiekvienai fazei asimetriniam reaktyviosios galios kompensavimui žemos įtampos tinkle. Sukurtas naujas kompensatorius su šuntu, skirtas tolydžiam, asimetriniam reaktyviosios galios kompensavimui žemos įtampos tinkle. Sukurtų reaktyviosios galios kompensatorių tyrimas buvo atliktas modeliuojant ir eksperimentiškai.

Disertaciją sudaro ịvadas, trys skyriai, bendros išvados, literatūros sąrašas ir autoriaus publikacijų disertacijos tema sąrašas.

Ivadiniame skyriuje aprašyta tyrimo problema, darbo aktualumas, tyrimo objektas. Pateikiamas darbo tikslas ir uždaviniai, tyrimo metodika, darbo mokslinis naujumas, darbo rezultatų praktinè reikšmè, ginamieji teiginiai. İvado pabaigoje pateikiamas autoriaus publikacijų ir konferencijų disertacijos tema sąrašas, disertacijos struktūra.

Pirmajame skyriuje analizuojami reaktyviosios galios kompensavimo metodai ir kompensatoriu tipai. Nagrinejjami reaktyviosios galios kompensatoriai su inverteriu ir su šuntu. Pateikiamos išvados ir suformuluojami disertacijos uždaviniai.

Antrajame skyriuje analizuojami reaktyviosios galios kompensatoriai su klasikiniu ir su kaskadiniu inverteriais. Siūlomos kompensatorių, skirtų asimetriniam reaktyviosios galios kompensavimui, schemos su individualiais kiekvienai fazei klasikiniais ir kaskadiniais inverteriais. Sukurti Matlab/Simulink kompensatorių modeliai ir atliktas kompensatorių tyrimas modeliuojant.

Trečiajame skyriuje pateiktas sukurtas kompensatorius su šuntu, skirtas tolydžiam asimetriniam reaktyviosios galios kompensavimui žemos ịtampos tinkle. Kompensatorius ištirtas modeliuojant Matlab/Simulink programa ir eksperimentiškai, naudojant sukurtą kompensatoriaus maketą.

Pagrindiniai disertacijos rezultatai paskelbti keturiose mokslinėse publikacijose - trys iš jų paskelbti recenzuojamuose mokslo žurnaluose, vienas - konferencijos pranešimų leidiniuose. Rezultatai buvo pristatyti penkiuose mokslinèse konferencijose. 


\section{Symbols}

$f_{\mathrm{c}}-$ carrier frequency

$f_{\mathrm{p}}$ - phase frequency

$n$ - modulation index

$P$ - active power

$Q$ - reactive power

$\delta$ - voltage phase angle

\section{Abbreviations}

FTMC - State Research Institute Center for Physical Sciences and Technology

IGBT - Insulated Gate Bipolar Transistor

MOSFET - metal-oxide-semiconductor field-effect transistor

PWM - pulse width modulation

RES - renewable energy source

$\mathrm{SAPF}$ - shunt active power filter

STATCOM - static synchronous compensator 
SVC - static VAR compensator

TCR - thyristor controlled reactor

TSC - thyristor switched capacitor

TSR - thyristor switched reactor

VAR - reactive Volt Ampere 


\section{Contents}

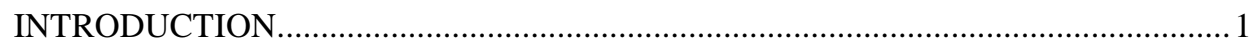

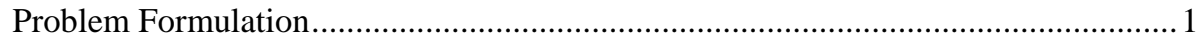

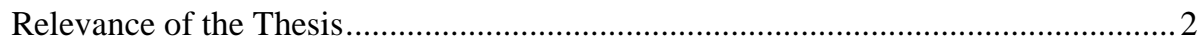

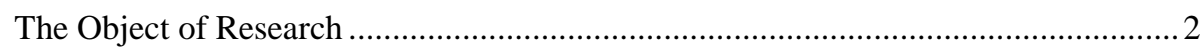

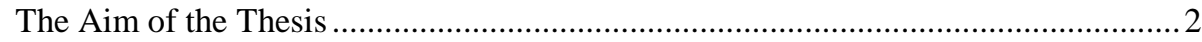

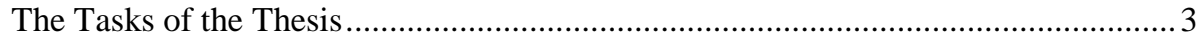

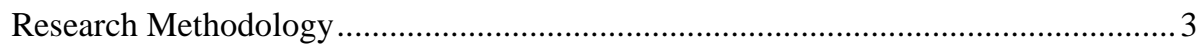

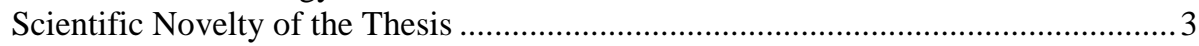

Practical Value of the Research Findings ................................................................ 4

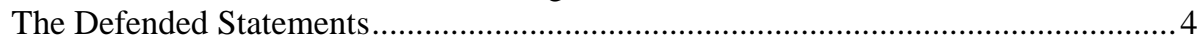

Approval of the Research Findings .....................................................................

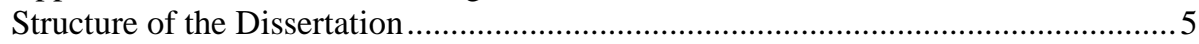

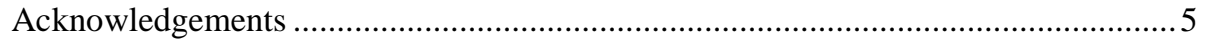

1. OVERVIEW OF REACTIVE POWER COMPENSATORS AND THEIR

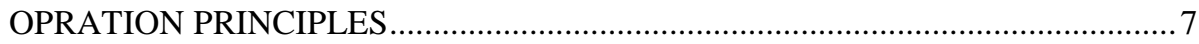

1.1. Reactive Power Compensation Techniques …………………………................ 7

1.2. Inverter based Reactive Power Compensators ................................................. 9

1.3. Inverter for Reactive Power Compensation.................................................... 10

1.3.1. Conventional Three-Phase Compensator .................................................... 10

1.3.2. Single-Phase Cascaded Inverter based Compensator .................................... 11

1.3.3. Three-Phase Cascaded Inverter based Compensator ...................................... 12

1.3.4. Two Level Four-Leg Three-Phase Inverter ………...................................... 13 
1.3.5. Reactive Power Compensation in the Distributed Utility Grid.................... 13

1.3.6. Renewable Energy Source Supplied Reactive Power Compensators .......... 14

1.3.7. Transformer-Clamped Multilevel Inverter ................................................ 15

1.4. Shunt-Connected Reactive Power Compensators .............................................. 16

1.4.1. Thyristor Switched Capacitor ....................................................................... 17

1.4.2. Thyristor Controlled Reactor ........................................................................ 18

1.4.3. Shunt-Connected Reactive Power Compensator .......................................... 20

1.5. Conclusions of Chapter 1 and Formulation of the Thesis Objectives ................21

2. ASYMMETRIC INVERTER BASED REACTIVE POWER COMPENSATORS ...23

2.1. Development of the Cascaded Inverter based Single-Phase Compensator......... 23

2.1.1. Conventional Inverter based Single-Phase Compensator ............................. 23

2.1.2. Cascaded Inverter based Single-Phase Compensator ................................... 27

2.2. Asymmetric Three-Phase Inverter based Reactive Power Compensator............. 32

2.2.1. Conventional Inverter based Reactive Power Compensator ........................ 32

2.2.2. Asymmetric Reactive Power Compensator with the Individual

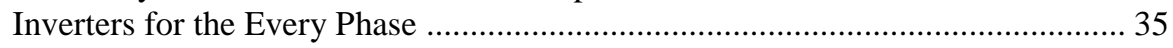

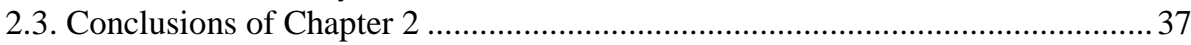

\section{ASYMMETRIC SHUNT-CONNECTED REACTIVE POWER}

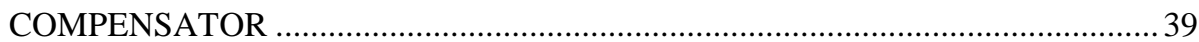

3.1. Principle of the Smooth Shunt-Connected Reactive Power Compensator ......... 39

3.2. Matlab/Simulink Simulation of Shunt-Connected Reactive Power

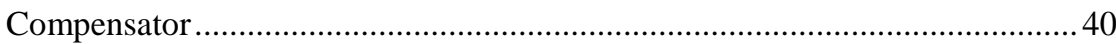

3.3. Implementation of the Symmetric Shunt-Connected Reactive Power

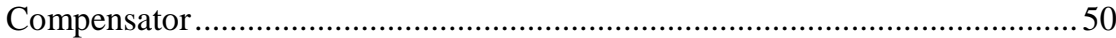

3.4. Development of the Asymmetric Shunt-Connected Reactive Power

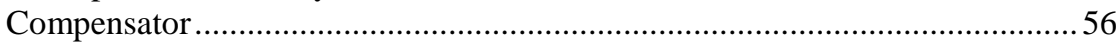

3.4.1. Test Bench of the Asymmetric Shunt-Connected Reactive Power

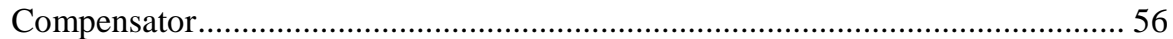

3.4.2. Investigation of the Compensator based on a Single Cored Three-Phase

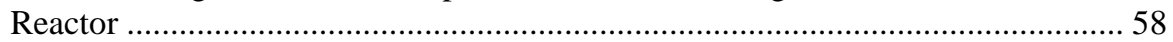

3.4.3. Investigation of the Separate Reactors for the Every Phase based

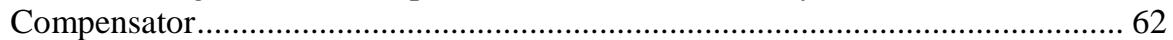

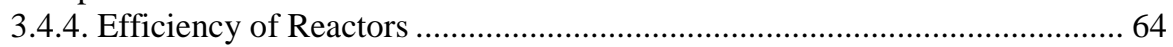

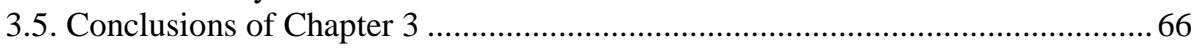

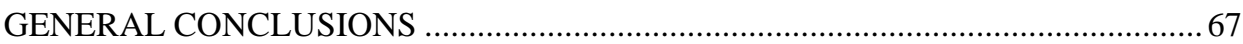

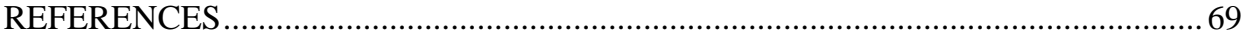

LIST OF SCIENTIFIC PUBLICATIONS BY THE AUTHOR ON THE TOPIC OF THE

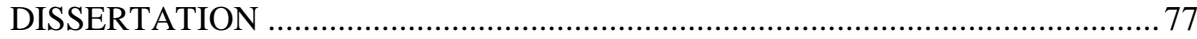

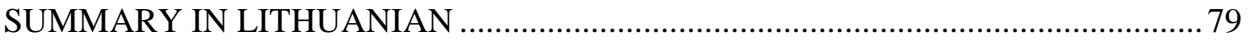




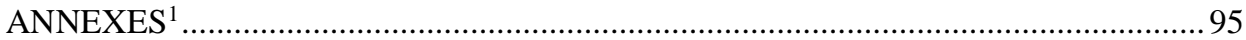

Annex A. Declaration of Academic Integrity .................................................. 96

Annex B. The co-authors agreements to present publications for the dissertation

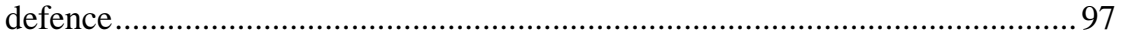

Annex C. Copies of scientific publications by the author on the topic of the dissertation.

${ }^{1}$ The annexes are supplied in the enclosed compact disc. 



\section{Introduction}

\section{Problem Formulation}

Grid power systems supply and use two types of electrical energy: active and reactive. Only the active energy consumed performs useful work. Reactive energy just pulsates between the power supply and the reactive load and introduces unnecessary energy losses. The reactive power is produced or consumed by the grid loads that include not only an active but also a reactive component. It can be introduced by harmonic distortions of grid current caused by the nonlinear loads as well. The reactive power increases the current in grid transmition lines, cables, transformers and switches, i.e. the reactive power influence as additional not useful load. Therefore, if reactive energy is generated or used, the grid installation must be designed for higher power taking into account not just the active but the reactive power as well. Consumers also have to account the reactive energy and pay the grids for it.

Small, grid-connected photovoltaic and wind power plants, amount of which is constantly growing, introduce one more problem related to reactive power because they can generate the reactive power to low voltage lines as well.

In summary, the following problems of reactive power compensation in low voltage grid, which are solved in the dissertation, can be formulated: the problem 
of smooth compensation of reactive power; the problem of asymmetric compensation of reactive power.

In order to solve the problem, these hypotheses were raised and proven: the conventional and cascaded inverter based reactive power compensators with the individual inverters for the every phase can perform the asymmetric compensation of reactive power in low voltage grid; shunt-connected reactive power compensator with single phase air gaped reactors is suitable for the smooth and asymmetric compensation of reactive power in the low voltage grid.

\section{Relevance of the Thesis}

The quality of the electricity is of strategic importance as it determines the reliability, efficiency and safety of energy supply. The generation, transmition and consumption of electricity are complex processes and one of the negative phenomenon of these processes that worsens the power quality is the reactive power. It is unavoidable in electrical grid and is introduced by the loads, which consume not just active power but the reactive power as well. It is highly important to compensate the reactive power, to improve the quality of electricity. Therefore, means for the compensation of the reactive power are constantly being improved and increasingly used. Because of this, research is dedicated to the development of more advanced reactive power compensators, which allows more efficient compensation of the reactive power in the low voltage grid, is relevant and has a practical value.

The relevance of the results presented in the dissertation is proved as well by the fact that this research was initiated and financed by a high-tech company developing and producing reactive power compensators.

\section{The Object of Research}

The object of research are smooth and asymmetric inverter based and shunt-connected reactive power compensators for the low voltage utility grid.

\section{The Aim of the Thesis}

The aim of the thesis is the development of reactive power compensators for the smooth and asymmetric reactive power compensation in the low voltage utility grid. 


\section{The Tasks of the Thesis}

To achieve the aim of the thesis, the following tasks are solved:

1. To modify and adapt the cascaded inverter for smooth reactive power compensation in the low voltage utility grid.

2. To develop the conventional and cascaded inverter-based reactive power compensator topologies with the individual inverters for the every phase for the asymmetric compensation of reactive power in the low voltage utility grid.

3. To develop the reactive power shunt-connected compensator with the thyristor controlled reactor for the smooth and asymmetric compensation of reactive power in the low voltage utility grid.

\section{Research Methodology}

Analytical techniques, simulation and experimental investigation have been used. The simulation was performed using Matlab/Simulink software. Experimental results are obtained employing the test bench of the shunt-connected reactive power compensator for the smooth and asymmetric reactive power compensation in the low voltage utility grid. The software for the controller of the test bench has been developed employing FB and IL programming languages.

\section{Scientific Novelty of the Thesis}

1. The novel topology of cascaded inverter-based reactive power compensator for the smooth asymmetric compensation of the reactive power in the low voltage utility grid has been proposed.

2. The novel topology of conventional and cascaded inverter-based reactive power compensators with the individual inverters for the every phase for the asymmetric compensation of reactive power in the low voltage utility grid has been proposed.

3. The novel shunt-connected reactive power compensator with the thyristor controlled reactor for the smooth and asymmetric compensation of reactive power in the low voltage utility grid has been developed. 


\section{Practical Value of the Research Findings}

The research results achieved in the process of doctoral research were applied in the project "Development of a steeples reactive power compensator", No. 3400S510, which was carried out in period (2018-2019) by the Laboratory of Electronic Systems of the Center for Physical Sciences and Technology. The project was the part of the program J05-LVPA-K, Intelektas - Common Science and Industry Projects, financed by the Lithuanian Business Support Agency (LVPA). Project partner was UAB "Elgama sistemos".

\section{The Defended Statements}

1. The cascaded inverter-based compensator implemented using two in series connected inverters, one of which operates at grid frequency and another one - at higher frequency using PWM technique, allows to develop the compensator using the combination of thyristor-based and MOSFET transistor-based inverters.

2. Conventional and cascaded inverter-based reactive power compensators with the individual inverters for the every phase with neutral connection are capable to provide asymmetric compensation of reactive power in the low voltage utility grid.

3. Shunt-connected reactive power compensator with the thyristor controlled reactor, which typically is used in high and medium voltage utility grid, can be implemented in the low voltage utility grid for the smooth and asymmetric compensation, employing single phase air gapped reactors using $\mathrm{Y}$ connection with connected to neutral midpoint.

\section{Approval of the Research Findings}

4 scientific articles have been published on the topic of the dissertation: 3 in peerreviewed scientific journals and 1 in conference proceedings.

The author has made 6 presentations at 5 scientific conferences:

- FizTech2015 PhD. Student conference. Vilnius, 2015;

- FizTech2016 PhD. Student conference. Vilnius, 2016;

- 20-th Lithuanian young scientists conference "Science - Future of Lithuania", Vilnius, 2017; 
- 21-th international conference "Electronics 2017”, Palanga, 2017;

- 22-nd Lithuanian young scientists conference "Science - Future of Lithuania”, Vilnius, 2019.

\section{Structure of the Dissertation}

The dissertation consists of an introduction, three chapters, general conclusions, lists of references and author's publications on the subject of the dissertation, a summary in Lithuanian.

The total scope of the dissertation - 93 pages excluding annexes, 10 numbered equations, 52 pictures, 3 tables and 82 references.

\section{Acknowledgements}

First, I would like to thank my supervisor Prof. Dr Algirdas Baškys and my wife Milda for their support, encouragement and patience during all this time. I would not have made it without You.

I am also very grateful to my internship supervisor at Ben-Gurion University of the Negev Prof. Dr Raul Rabinovici, Your ideas and advices made a huge impact on my research.

I would also like to thank all laboratory of electronic systems (laboratory of microelectronics before) of state research institute Center for Physical Sciences and Technology, especially Dr Vytautas Bleizgys for helping with research and many more. I am also very grateful to Aldas Dervinis, Dalius Augustinas and Vitoldas Gobis for their support.

I am also very grateful to UAB Lietpak, especially to Vaclovas Vincel, Dr Pranas and Andrius Kizniai for their invaluable support and believe in my work. I would also like to thank technical department: Aleksej, Tomas, Marius, Eduard and all the others for their collaborative effort during all research.

At last, I would like to thank my mom and my children, who never stopped believing in me, thank You for being near.

Thank You All,

Martynas Šapurov 



\section{1}

\section{Overview of Reactive Power Compensators and their Operation Principles}

This Chapter reviews the types and properties of reactive power compensators. The reactive power compensation techniques and different topologies of inverter based reactive power compensators are analyzed in the first part of the chapter. The second part of the chapter covers the shunt-connected reactive power compensators. The conclusions of the first chapter are presented and the dissertation tasks are formulated. The obtained results have been published in two publications (Šapurov, Bleizgys, et al., 2020; Sapurov et al., 2017).

\subsection{Reactive Power Compensation Techniques}

The reactive power is produced or consumed by the grid loads that include not only an active but also a reactive component. Reactive power acts as additional load of the grid, which is incapable of producing effective work, therefore it requires compensation. Reactive power is introduced by inductive and capacitive loads and by nonlinear loads as well. However, the reactive power can be produced by grid-connected photovoltaic and wind power plants, the number of 
which is constantly growing. The reactive power appears when there is phase displacement between the grid current and voltage and is measured in volt-ampere reactive (VAR) units.

One of the now-days main problems of the electrical grid is compensation of the reactive power in the low voltage grid (Ali et al., 2018; Arshad \& Lehtonen, 2018; Balcells \& Bogónez-Franco, 2013; Beck, Berlovich, \& Braunstein, 2016; Beck, Berlovich, Muller, et al., 2016; Bielskis et al., 2020; Bogónez-Franco et al., 2011; Charalambous et al., 2019; Deblecker et al., 2016; Dong et al., 2012; Gayatri et al., 2018; Ilisiu \& Dinu, 2019; Li et al., 2011; Merai et al., 2015; Santacana et al., 2010; Stanelyte \& Radziukynas, 2020; Trentini et al., 2012; Xu et al., 2010; Yong Xue et al., 2009) Since the low-voltage three-phase lines are often loaded asymmetrically (Charalambous et al., 2019; Pană et al., 2018a, 2018b; Tong XiangQian et al., 2005), the low voltage three phase lines are often loaded asymmetrically, i.e. the reactive power, which has to be compensated, is different in different phases.

Most of grid equipment that introduce the reactive power, such as electric motors, induction heating devices, ballasts operate as inductive loads. Because of this, the most part of reactive power compensation systems in low voltage lines of the utility grid are based on the electro-mechanical commutation technology of capacitor banks, which are split into steps connected in parallel to the utility grid. However, capacitor banks have fixed discrete reactive power capacity, i.e. the reactive power produced by the capacitor bank cannot be changed smoothly. Therefore, it is impossible to fully compensate reactive power of the utility grid using capacitor banks.

The considerable amount of nowadays utility grid power in consumed by inductive loads as electric motors, transformers, induction heating devices. Therefore conventional reactive power compensation system in the low voltage lines employs capacitor banks split into steps connected in parallel to the utility grid. Main disadvantage of compensators based on the capacitor banks is a fact that the reactive power produced by the capacitor bank is changed discretely, i.e. there is no possibility of fine-tuning the reactive power and, as a consequence, fully compensate it in the utility grid. These compensators are capable to compensate only symmetrical inductive loads; however, reactive grid loads often are asymmetrical, i.e. different in different phases and can by of capacitive type as well.

There two main types of compensators that provide smooth compensation of inductive and capacitive reactive power:

1. Inverter-based reactive power compensators.

2. Shunt-connected reactive power compensators.

Inverter-based reactive power compensators usually are named as STATCOM. They are based on the inverter, which acts as voltage source and using $\mathrm{PWM}$ technique generates $\mathrm{AC}$ voltage synchronized with the grid voltage $(P Q C$ - 
STATCON, 2011; Yan, 2015). Dependent on voltage amplitude it compensates smoothly the inductive or capacitive reactive power. Capacitance reactive power is supplied if inverter provided voltage amplitude is higher than voltage amplitude of the utility grid. In case inverter provided voltage amplitude is lower than voltage amplitude of the utility grid inductance reactive power is consumed. In case inverter provided volt-age, amplitude is equal to the utility grid voltage reactive power is not produced or consumed. Converter based reactive power compensators have fast response time, are capable of full reactive power compensation. The main disadvantages is that STATCOM is not capable to compensate asymmetric reactive loads.

Shunt-connected reactive power compensator is based on thyristor-switched capacitor - TSC for discrete capacitor bank capacity variation and thyristor-controlled reactors - TCR for smooth reactive power compensation (Mahapatra et al., 2014; Sullivan, n.d.). While TCR allows adjusting the re-active power smoothly. The smooth adjusting of inductive reactive power using TCR is provided by finetuning of duration, during the which the re-actor during every grid voltage halfperiod is connected to the grid. Shunt-connected reactive power compensator approach is much cheaper in comparison with the inverter based reactive power compensators, and they can provide asymmetric compensation, however, such compensators are developed just for high voltage lines of the utility grid (Dixon et al., 2005; Gayatri et al., 2018; D. I. Panfilov \& ElGebaly, 2016; Sethi et al., 2014).

\subsection{Inverter based Reactive Power Compensators}

Conventional energy transfer technique consists of two voltage sources, where one is supplying power. Voltage sources could not be connected in parallel, therefore inductance is being employed. Simplified conventional energy grid diagram is presented in Fig. 1.1.

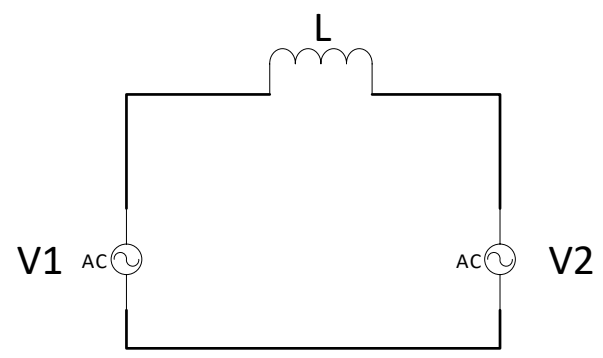

Fig. 1.1. Simplified energy transfer diagram between two voltage sources 
The energy transferred to the grid can be controlled in two ways: by variation of inverter voltage amplitude and by variation of voltage phase angle $\delta$. Active $(P)$ and reactive $(Q)$ power values can be obtained using equations (Haykin \& Van Veen, 2003; Rozanov et al., 2016):

$$
P=\frac{V_{1} V_{2} \sin \delta}{X}, Q=\frac{V_{1} V_{2} \cos \delta-V_{2}^{2}}{X} .
$$

It could be observed that $P$ and $Q$ are coupled among themselves. However, they could be decoupled under certain circumstances. Assuming that $\delta$ is very small, therefore equations could be considered:

$$
\begin{aligned}
& \sin \delta \approx \delta, \text { when } \delta \rightarrow 0 ; \\
& \cos \delta \approx 1, \text { when } \delta \rightarrow 0 .
\end{aligned}
$$

Adding obtained values to 1.1 new equations for $P$ and $Q$ could be obtained:

$$
\begin{gathered}
P \approx \frac{V_{1} V_{2} \delta}{X}, \text { when } \delta \rightarrow 0 ; \\
Q \approx \frac{V_{1} V_{2}-V_{1}^{2}}{X}, \text { when } \delta \rightarrow 0 .
\end{gathered}
$$

It is seen (1.3) that reactive power produced by the inverter-based reactive power compensator depends on the output voltage amplitude. In the situation when $V_{1}>V_{2}$, reactive power $Q<0$, i.e. If $V_{1}<V_{2}$, reactive power $Q>0$, i.e. a dependent on amplitude value compensator acts as a capacitive or inductive load. It is obvious that $P \approx 0$, when $\delta$ is very small, therefore, an inverter can compensate the reactive power with low active power losses.

\subsection{Inverter for Reactive Power Compensation}

\subsubsection{Conventional Three-Phase Compensator}

The H-bridge-based single-phase inverter is usually employed for three level applications, see Fig. 1.2. (Neves et al., 2009). Power stage of H-bridge inverter consists of four IGBT transistors with parallel diodes, a DC part uses capacitors or batteries for renewable energy storage; an output filter is employed for carrier frequency cancelation. Presented topology is a conventional technique for single phase shunt active power filter and renewable energy source supply applications (Padiyar, 2007; Rozanov et al., 2016). 


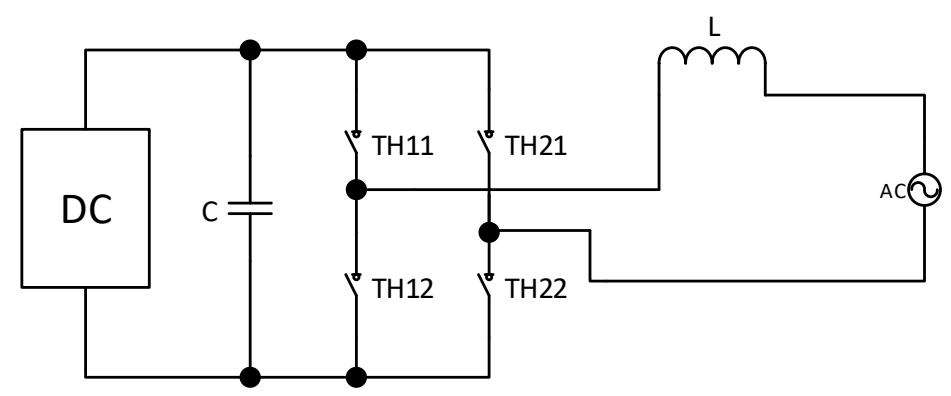

Fig. 1.2. Schematics of three level H-bridge single-phase inverter

\subsubsection{Single-Phase Cascaded Inverter based Compensator}

Cascaded inverters are usually employed in high voltage high power applications. The switching devices are connected in series in high voltage applications reducing the voltage of each switch. Each cascade is supplied with isolated voltage source, therefore a cascaded inverter can provide voltage of seven levels at output, causing lower THD. Employment of cascaded inverter could also reduce the harmonic spectrum currents and voltages. At the same time, the employment of cascaded inverter could reduce switching losses and noise. Schematics of the singlephase cascaded inverter is presented in Fig. 1.3. (P \& Mahapatra, 2011; Padiyar, 2007; Rao et al., 2013; Rozanov et al., 2016).

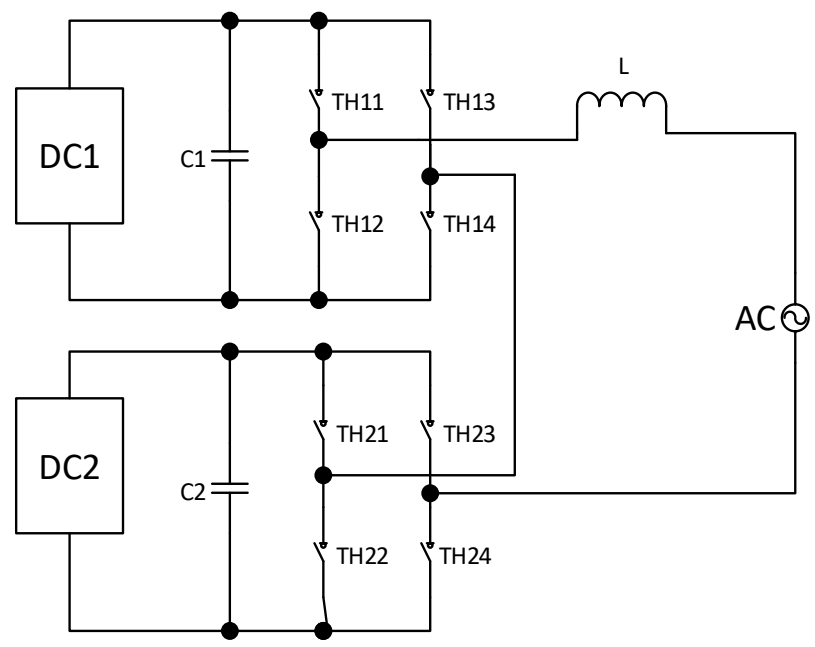

Fig. 1.3. Schematics of single phase cascaded inverter 


\subsubsection{Three-Phase Cascaded Inverter based Compensator}

This approach covers implementation of cascaded inverter in compensator application. It results in a good dynamic performance under both steady state and transient operations. The DC-bus capacitor voltage of cascaded inverter is controlled by PI-controller. Employment of cascaded inverter in active power system provides effective compensation of harmonics and facilitates power factor correction.

Generalized power theory for sinusoidal or non-sinusoidal, balanced or unbalanced three-phase power system with or without zero-sequence currents employs compensator connected in series or in parallel with supply network (Holms $\&$ Lipo, 2003). The series connection is suitable for voltage harmonic compensation. Industrial applications are mostly in need of current harmonics compensation; therefore, the shunt-connected compensator (parallel connection) is mostly used. Development of insulated-gate bipolar transistors (IGBT) caused rapid growth of interest in inverter based compensators (P \& Mahapatra, 2011). The compensator generates the currents required to compensate distorted line current and reactive power.

Cascaded inverter is employed to increase number voltage levels, causing lower switching losses and higher order harmonics compensation. The cascade inverter consists of full bridge inverters supplied with separate dc sources. Topology of cascaded inverter based compensator is presented in Fig. 1.4 (Macken et al., 2004).
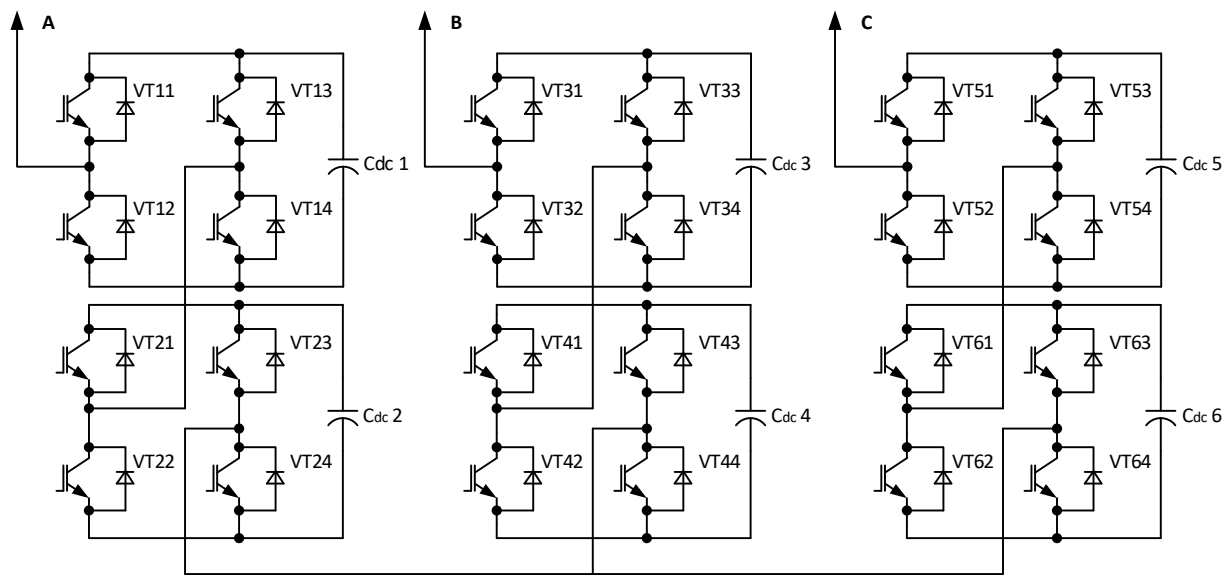

Fig. 1.4. Cascaded inverter based compensator topology 


\subsubsection{Two Level Four-Leg Three-Phase Inverter}

Four-leg inverter is commonly used in three phase utility grid for current unbalance and neutral current compensation along with harmonic current elimination and reactive power compensation. Three legs supply phase currents to the utility grid, while fourth leg increases amount of switching states, which allows neutral current compensation and improves output voltage quality, see Fig. 1.5. (Acuña et al., 2014; Babu et al., 2013; Bala Nikilesh \& Nageswara Rao, 2015; Barbosa et al., 1998; Dineshkumar \& Senthilnathan, 2014; Gururaj M V et al., 2015; Ilango et al., 2012; Padiyar, 2007; Pouresmaeil et al., 2015; Singh et al., 2011). Passive filter is employed for carrier frequency elimination.

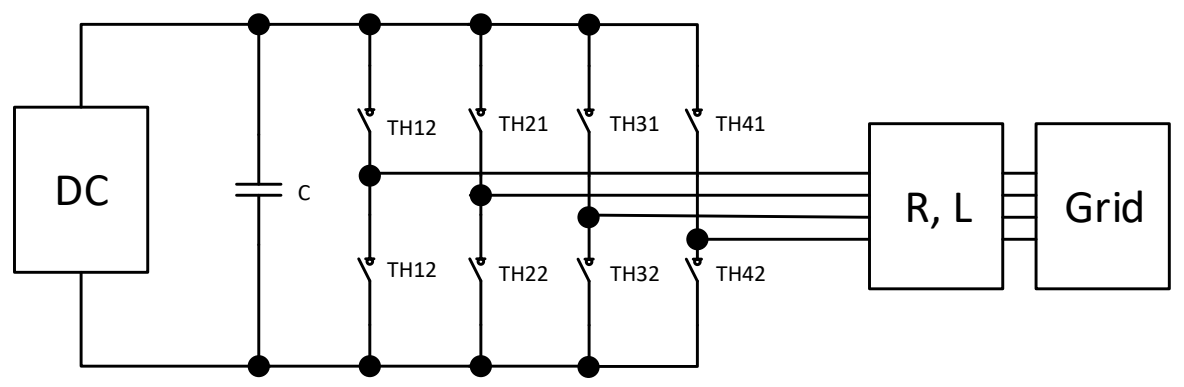

Fig. 1.5. Circuit diagram of two level four leg three-phase inverter

RES could serve as power supply for two level four leg inverter. Renewable energy should be harvested implementing MPPT techniques and conditioned as DC source. However, employing two level inverter as shunt active power filter is complicated due high THD of two level PWM. Therefore, current harmonic elimination could not provide the best quality.

\subsubsection{Reactive Power Compensation in the Distributed Utility Grid}

Utility grid could be supplied with reactive power as well as active power, providing reactive power compensation capabilities. Such approach is considered a renewable energy generation with compensator capability. Supply power should be driven from renewable energy sources: solar, wind and biomass. Renewable energy sources usually provide DC current, either AC current witch is not synchronous to the utility grid, therefore it requires power electronics converter. The growth of interest in inverters with additional features, like reactive power and harmonic compensation, could be considered in deregulated electricity market. 
Conventional renewable energy converters are usually designed for maximal active energy production. To be noticed, that amount of available active power $(P)$ is rarely at its maximum, consequently the amount of reactive power $(Q)$ is sufficient for compensating purposes most part of the time at wind energy system (Bielskis et al., 2020; Macken et al., 2004; Pikutis et al., 2014).

In distributed system among several inverters connected to the grid all units are connected in common network causing them to act as a single unit. Singlephase source inverter with simplified control loop is presented in Fig. 1.6 (Pikutis et al., 2014).

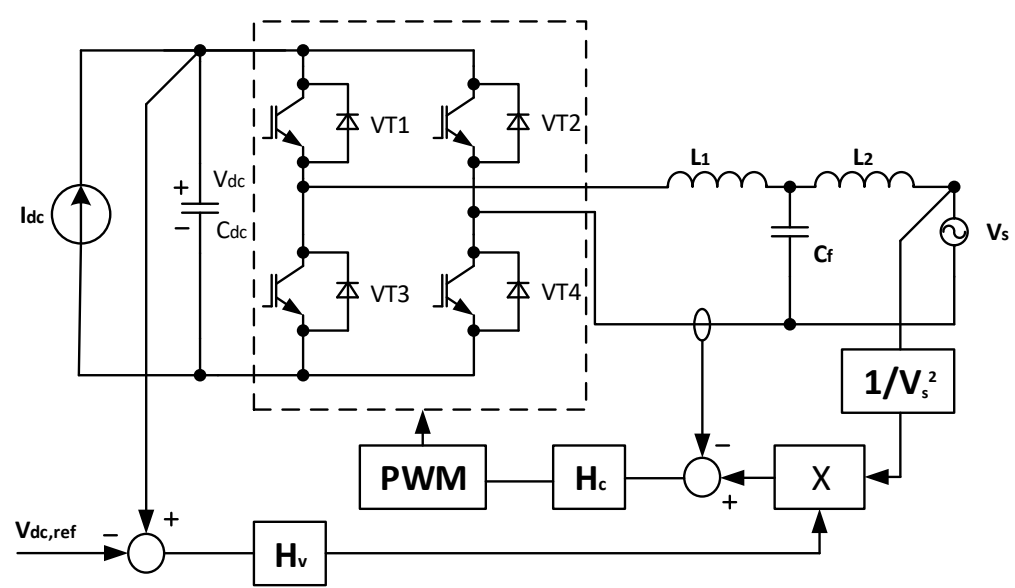

Fig. 1.6. Single-phase source inverter with simplified control loop

The controller of presented inverter consists of inner current control loop Hc and outer voltage control loop Hv. Voltage controller maintains certain DC bus value and provides reference value for the current. Increase of DC voltage causes growth of current drawn from the DC bus, resulting decrease of dc bus voltage. Decrease of DC voltage results in lower current driven from the DC bus, therefore DC bus voltage increases. Current controller feeds PWM unit, supplying desired amount of current to the utility network (Macken et al., 2004).

\subsubsection{Renewable Energy Source Supplied Reactive Power Compensators}

Inverter that could be utilized for renewable energy source power injection into the grid, as well as shunt connected compensator to compensate current unbalance, load current harmonics. Topology of three-phase four-wire connection also 
gains possibility of current unbalance and neutral current compensation. Schematics of reactive power compensator supplied by renewable energy source is presented in Fig. 1.7 (Singh et al., 2011; Vechiu et al., 2015).

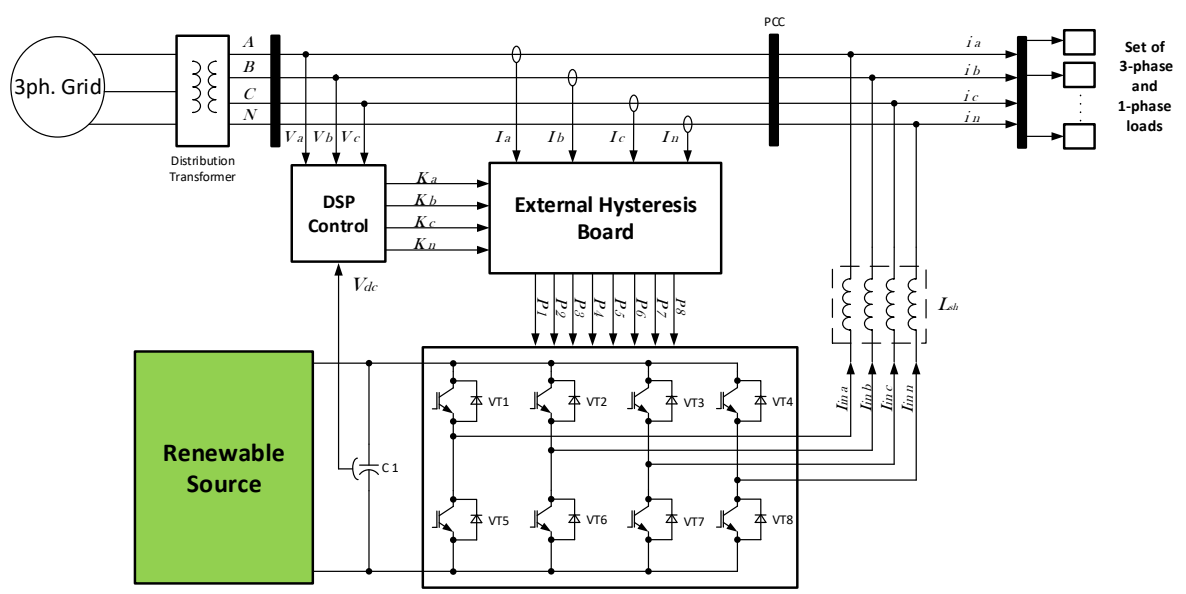

Fig. 1.7. Schematics of reactive power compensator supplied by renewable energy source

Compensator can perform following function separately and simultaneously:

1. Supply the renewable energy sources power to the utility grid.

2. Fulfill load reactive power demand.

3. Compensate current harmonics.

4. Compensate neutral current.

Compensator consists of renewable energy source connected to the utility grid employing four-leg inverter. Renewable energy source could serve as AC or DC energy source depending on its type. Any type of renewable source energy needs conditioning before connecting to the DC link of the inverter (i.e. DC/DC or AC/DC). System transfers fundamental active power to the utility grid all the time. In case non-linear or unbalanced load compensation of the harmonics, unbalance and neutral current is performed. The DC-bus voltage is maintained constant by employing PI-controller. PI-controller performance is based on the control of the active and reactive power supplied to the utility grid.

\subsubsection{Transformer-Clamped Multilevel Inverter}

Transformer clamped multilevel topology allows to increase the number of output voltage levels in the output of multilevel inverter. Therefore, waveform, which by 
the shape is closer to the pure sinusoid with lower THD, could be achieved. Presented topology consists of two inverter units considered as main an auxiliary inverter and two transformers. Both, main and auxiliary H-bridge inverters are connected to a single voltage source, see Fig. 1.8 (Jabir et al., 2013).

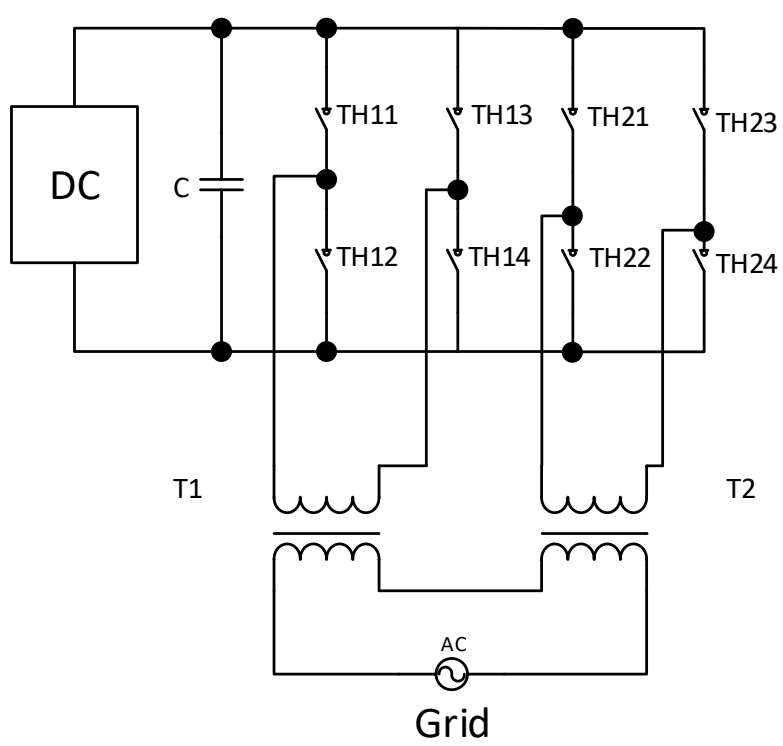

Fig. 1.8. Schematics of transformer-clamped multilevel inverter

Maximum number of output voltage levels depends on the rating of voltage source, which could be adjusted by selecting the ratio of primary and secondary transformer winding turns (Jabir et al., 2013).

\subsection{Shunt-Connected Reactive Power Compensators}

Shunt-connected reactive power compensators provide smooth reactive power compensation and usually are used in high and medium voltage utility grid. They include following functional blocks: thyristor switched capacitor (TSC), thyristor switched reactor (TSR) and thyristor controlled reactor. 


\subsubsection{Thyristor Switched Capacitor}

A conventional reactive power compensation system is usually implemented by connecting capacitor banks in parallel to the utility grid. For three phase applications capacitors can be connected in Y or $\Delta$ (Fig. 1.9). Capacitor banks are usually split in to several steps to gain more agility. The raising of capacitor bank power (connecting more steps) results in full reactive power compensation dramatically reducing power loss and overload of the utility grid (Mathur \& Varma, 2002; Padiyar, 2007; Singh et al., 2011).

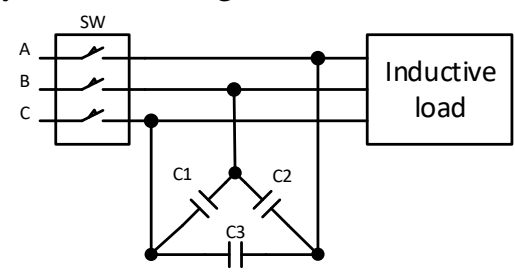

a)

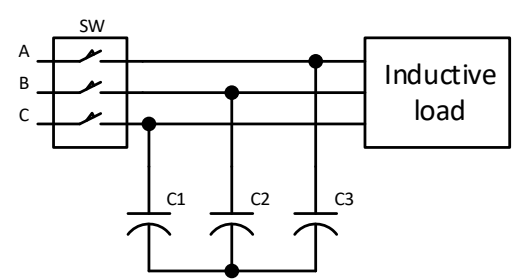

b)

Fig. 1.9. Schematics of capacitor connection: a) $Y$ connection; b) $\Delta$ connection

The presented technique is usually implemented in factories and other industries because it can be easily installed and requires little maintenance, energy losses are considered low as well. Nevertheless such system is incapable of fast response as switching of the capacitor causes current overshoots therefore the switching number per hour is usually limited. The second disadvantage is that capacitor banks are split into discrete steps this means reactive power cannot be fully compensated.

Reactive power compensation systems are presented as improvement of conventional discrete capacitor banks. Hence, improvement of reactive power control and enchantment of stability are the main goals of the approach. Main types of reactive power compensation systems are:

- Thyristor controlled reactor (TCR);

- Thyristor switched capacitor (TSC);

- TCR and fixed capacitor.

Thyristor switched capacitor circuit consists of bidirectional transistor switch for each capacitor connected in parallel to the utility grid. The schematics of thyristor switched capacitor compensator is presented in Fig. 1.10 (Mukhopadhyay et al., 2017, 2018; Patel \& Dubey, 1983; Singh et al., 2011, 2011). 


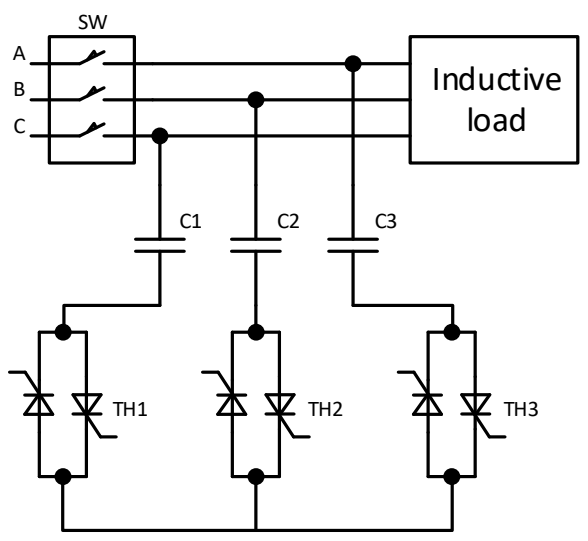

Fig. 1.10. Schematics of thyristor switched capacitor compensator

Capacitors can be switched on or off by controlling the firing angle of the bidirectional thyristor pair. For implementation of such control thyristor switches should be turned on or off at the peak of applied voltage, they should also be precharged for proper operation. Avoiding these conditions causes utility grid current overshoots, which could permanently damage the system.

\subsubsection{Thyristor Controlled Reactor}

Thyristor controlled reactor applications consist of bidirectional high power switch and reactance (coil). Air core reactors fit best, but due to the low efficiency air, gaped reactors are usually selected. Inductance supplied to the utility grid is controlled by changing firing angle: $90^{\circ}$ firing angle corresponds full conduction, at the firing angle of $180^{\circ}$, system does not provide utility grid with inductance. Therefore increasing the firing angle reduces the reactive power absorbed by reactor. It should be stressed that the control of the reactive power could be obtained only at discrete points; therefore, the lag of the continuous control could be up to half period of the utility grid. Usage of firing angle control results in generation of fundamental waveform odd harmonics. Thyristor controlled reactor is presented in Fig. 1.11 and voltage and current waveforms at different firing angle are presented in Fig. 1.12 (Awad et al., 2015; Mahapatra et al., 2014; Mathur \& Varma, 2002; Padiyar, 2007). 


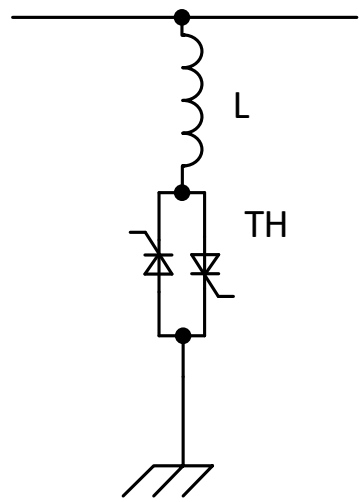

Fig. 1.11. Thyristor controlled reactor

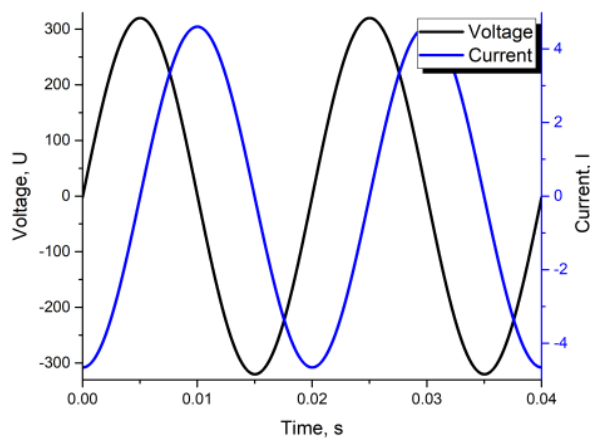

a)

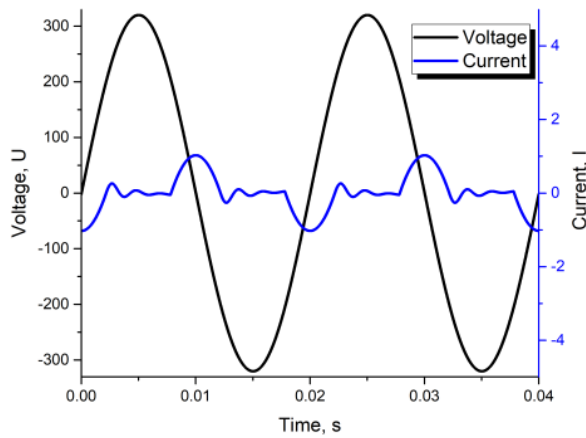

c)

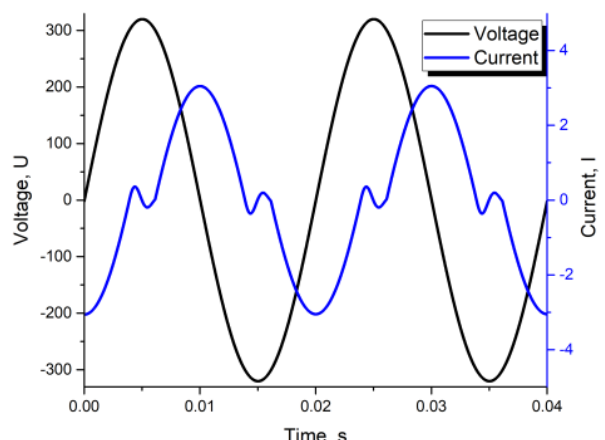

b)

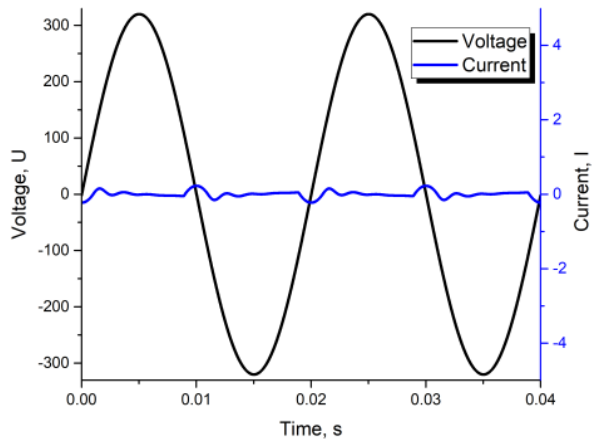

d)

Fig. 1.12. Voltage and current waveforms of thyristor controlled reactor at firing angle (a): a) $90^{\circ}$; b) $110^{\circ}$; c) $140^{\circ}$; d) $160^{\circ}$ 


\subsubsection{Shunt-Connected Reactive Power Compensator}

Shunt-connected reactive power compensators are used as improvement of conventional discrete capacitor banks. Hence, improvement of reactive power control and enchantment of stability are main goals of the approach. Usually it includes thyristor switched capacitor (TSC) and thyristor controlled reactor (TCR). TSC and TCR are connected in parallel (Fig. 1.13). This approach provides the possibility of consuming the reactive power by thyristor controlled reactor and supply of reactive power by the thyristor switched capacitor. Thyristor switched capacitor should be switched on at voltage zero crossing value for minimization of current overshoots and avoiding harmonics. Turn off position is obtained automatically as thyristor is switched of when current value fell below the holding current.

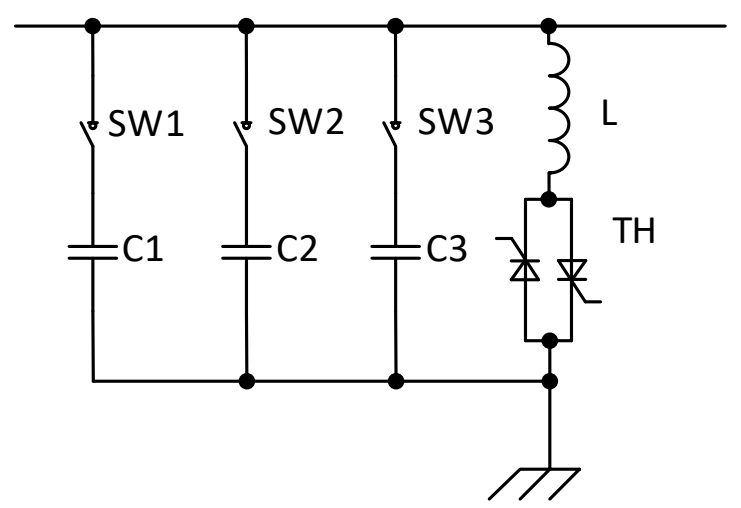

Fig. 1.13. Schematics of shunt-connected reactive power compensator

Thyristor controlled reactor inductance is controlled by the firing angle. Thyristor controlled reactor could be used for limiting voltage rises on lightly loaded transmission lines. Working in parallel allows the smooth overall reactive power control employing thyristor controlled capacitor for absorption of oversupplied capacitance.

The analysis of publications shows that the shunt-connected reactive power compensators based on the TSC and TCR is developed only for the symmetric compensation of the reactive power and practically is employed just for high and medium voltage lines of the utility grid (Acha, 2002; Čerňan \& Tlustý, 2015; Chang \& Liao, 2017; Dixon et al., 2005; Farkoush et al., 2016; Fuchs \& Masoum, 2011; Hong Hu et al., 2015; Igbinovia et al., 2015; Ilisiu \& Dinu, 2019; Liberado et al., 2013; Liu et al., 2016; Mathur \& Varma, 2002; Padiyar, 2007; D. I. Panfilov et al., 2017a, 2017b; Dmitry I. Panfilov et al., 2019; Rahmani et al., 2014; Tehrani et al., 2011; Tokiwa et al., 2017). There are few publications dedicated to shuntconnected reactive power compensators for the smooth compensation of reactive 
power in low voltage grid (Alkayyali \& Ghaeb, 2020; Balcells \& BogónezFranco, 2013; Beck, Berlovich, \& Braunstein, 2016; Beck, Berlovich, Muller, et al., 2016; Bogónez-Franco et al., 2011; Dong et al., 2012; Köse \& Irmak, 2016). However, all these publications are dedicated to symmetric compensation of reactive power in all three phases and in most of them just the simulation results are presented.

\subsection{Conclusions of Chapter 1 and Formulation of the Thesis Objectives}

1. The most part of the reactive power compensation systems in low voltage lines of the utility are based on the electro-mechanical commutation technology of capacitor banks, which are split into steps connected in parallel to the utility grid.

2. Capacitor banks have fixed discrete reactive power capacity, i.e. the reactive power produced by the capacitor bank cannot be changed smoothly. Therefore, it is impossible to fully compensate reactive power of the utility grid using capacitor banks.

3. The inverter-based reactive power compensators, which provide smooth reactive power compensation, are characterized by fast response time and are capable to compensate both capacitance and inductance reactive, however they are characterized by a high price and provide just symmetric compensation of reactive power in all three phases of the grid.

4. Cascaded inverter-based reactive power compensators are characterized by lower switching losses as compared to conventional inverterbased compensators and they can be implemented using transistors with lower operating voltage.

5. TCR based shunt-connected reactive power compensator is developed only for the symmetric compensation of the reactive power and just for high and medium voltage lines of the utility grid, and no one on the market offers the shunt-connected reactive power compensator for the smooth asymmetric compensation of the reactive power in the low voltage grid. 
To achieve the aim of the dissertation, the following tasks have to be solved:

1. To modify and adapt the cascaded inverter for the smooth reactive power compensation in the low voltage utility grid.

2. To develop the conventional and cascaded inverter-based reactive power compensator topologies with the individual inverters for the every phase for the asymmetric compensation of the reactive power in the low voltage utility grid.

3. To develop the shunt-connected reactive power compensator for the smooth and asymmetric compensation of the reactive power in the low voltage utility grid. 


\section{2}

\section{Asymmetric Inverter based Reactive Power Compensators}

This chapter presents the results of the development and investigation of the reactive power compensator topology based on the single cascaded inverter realized using combination of a thyristor and transistor-based $\mathrm{H}$ bridges. Circuits of compensators for the asymmetric compensation of the reactive power developed using individual conventional inverters and individual cascaded inverters for every phase are proposed in this chapter as well. The obtained results have been published in two publications (Šapurov, Dervinis, et al., 2020; Sapurov et al., 2017).

\subsection{Development of the Cascaded Inverter based Single-Phase Compensator}

\subsubsection{Conventional Inverter based Single-Phase Compensator}

The single-phase conventional inverter based compensator is investigated in this chapter. It is a part of widely used conventional inverter based three-phase compensators for the symmetric compensation of the reactive power. The results obtained in this chapter will be required for comparative evaluation of the proposed 
compensators with the individual inverters for the every phase for asymmetric compensation of reactive power. The single-phase conventional inverter based compensator consists of full bridge inverter, DC source and output low pass filter.

The main part of every inverter is leg, which consists of two in series connected MOSFET or IGBT transistors. The single-phase inverter consists of two legs (H-bridge), the three-phase inverter consists of three legs. The design of inverter leg is very important, because it determines the quality of output voltage (duration of pulse rising and falling edges), power losses and reliability of the inverter. The circuit diagram of inverter leg is presented in Fig. 2.1. The upper transistor VT1 is used to form the rising and lower one for falling edge of generated pulse. The $U_{\mathrm{EG} 1}$ stands as control signal of the upper transistor and $U_{\mathrm{EG} 2}-$ control signal of lower transistor. In Fig. 2.1 $C_{\mathrm{B}}$ stands for non-inductive capacitor for the cancelation of overvoltage introduced by switching of transistors. The appropriate capacity of this capacitor is determined by the parasitic inductances determined by the design solutions of the printed circuit board (conductors' length, angle of inclination and distance between conductors). Capacitor $C_{\mathrm{D}}$ and resistor $R_{\mathrm{D}}$ are parts of the RC snubber circuit, which has to be used to reduce the transistor overvoltage to increase the reliability of the transistor operation. At the same time, inclusion of snubber circuit increases the power losses of inverter as well. Therefore, the snubber circuit parameters have to be chosen in order to compromise between overvoltage elimination efficiency and power loss.

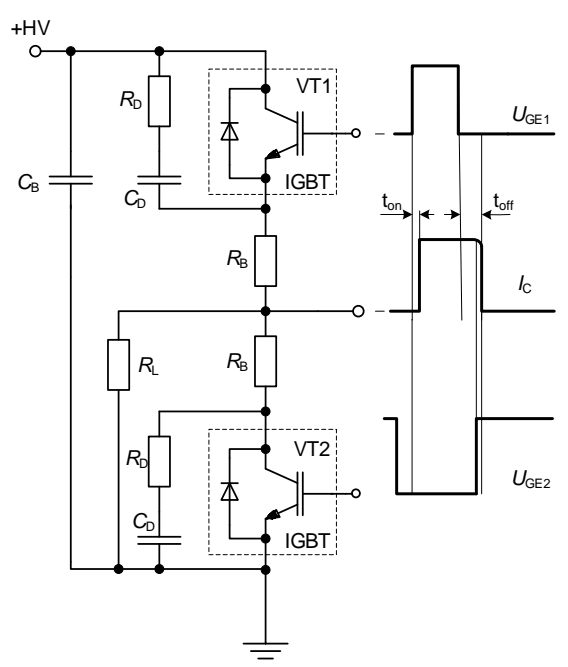

Fig. 2.1. The circuit diagram of inverter leg

The Matlab/Simulink model of inverter based single-phase compensator was developed for the investigation (Fig. 2.2). According to the law of energy transfer 
(1.3), supplied reactive power depends on the output voltage of the compensator. Inverter of the compensator produces PWM voltage to the utility grid employing low pass filter. The amplitude of the voltage is controlled by variation of PWM voltage duty cycle. Capacitance reactive power is supplied if the amplitude of the voltage provided by the compensator is higher than voltage amplitude of the utility grid. In case when the amplitude of the inverter voltage is lower than amplitude of the utility grid voltage, inductive reactive power is consumed.

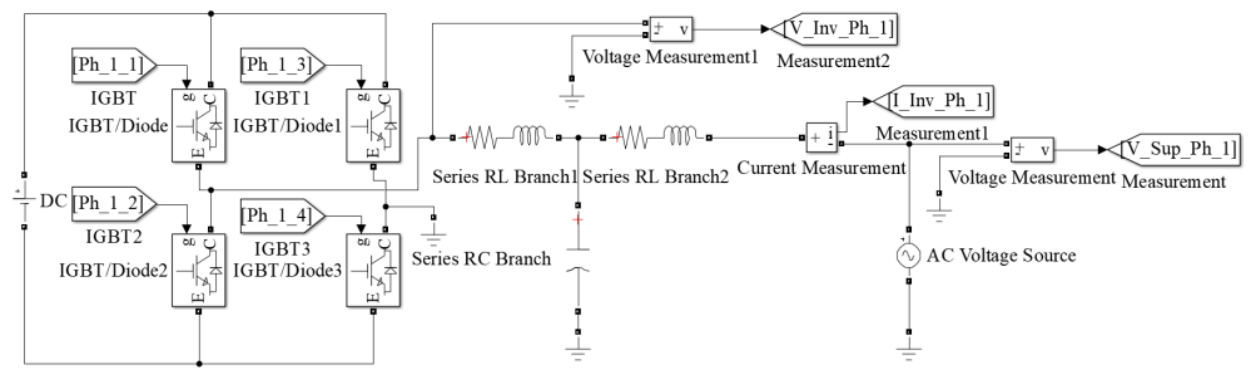

Fig. 2.2. Matlab/Simulink model of conventional inverter based single-phase reactive power compensator

The DC supply voltage of the analyzed compensator is $400 \mathrm{~V}$. The compensator allows to compensate capacitive and inductive reactive power up to $Q=$ $4 \mathrm{kVAr}$. The waveforms of grid voltage, compensator current, and spectrum of current are presented in Fig. 2.3. The current phase shift with respect to voltage shows that supply current in Fig. 2.3 a) is capacitive and in Fig. 2.3 b) is inductive.

In order to produce quality reactive power, the total harmonic distortion (THD) of compensator current has to be minimal. Therefore, it is of interest to know the relation between the reactive power produced or consumed by the compensator and THD. The value of reactive power consumed or produced by the compensator is varied by variation of compensator output voltage amplitude. The dependences of reactive power and THD on the amplitude are given Fig. 2.4. It can be noticed that the highest THD value of $45 \%$ is reached when the reactive power supplied by the compensator is minimal and it decreases when the absolute value of reactive power increases. This is due the fact that THD is measured relatively to the main harmonic amplitude, which increases with the reactive power. 


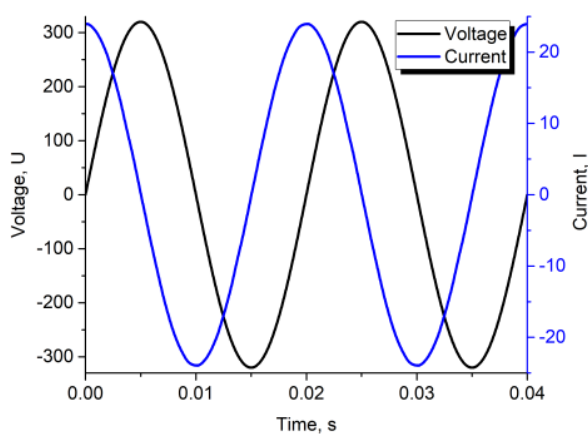

a)

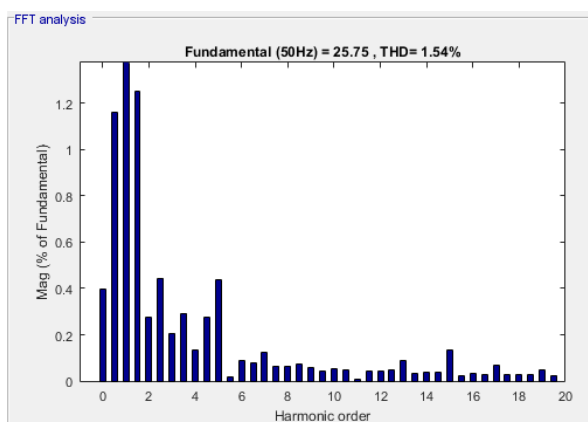

c)

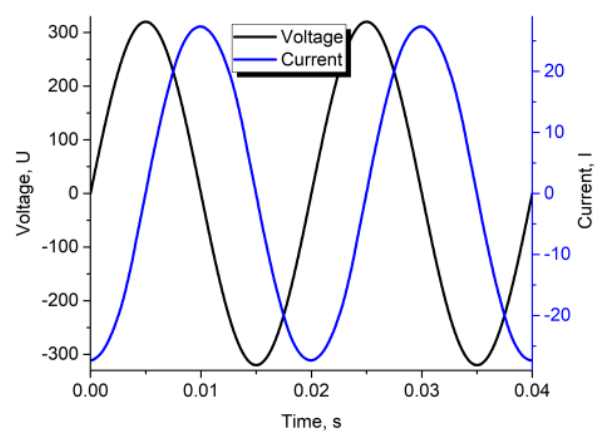

b)

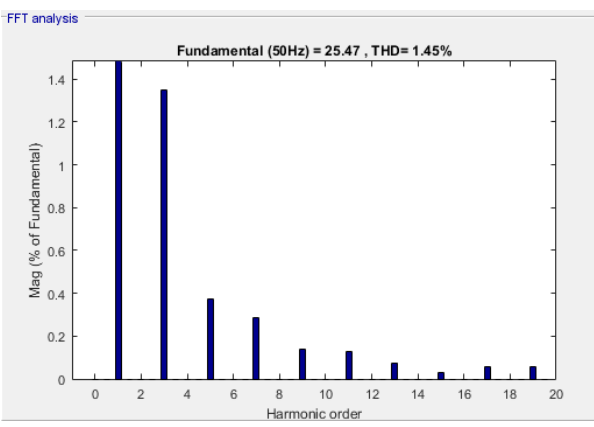

d)

Fig. 2.3. Waveforms and spectrums of the compensator current: a) waveform of inductive current; b) waveform of capacitive current; c) spectrum of inductive current;

d) spectrum of capacitive current

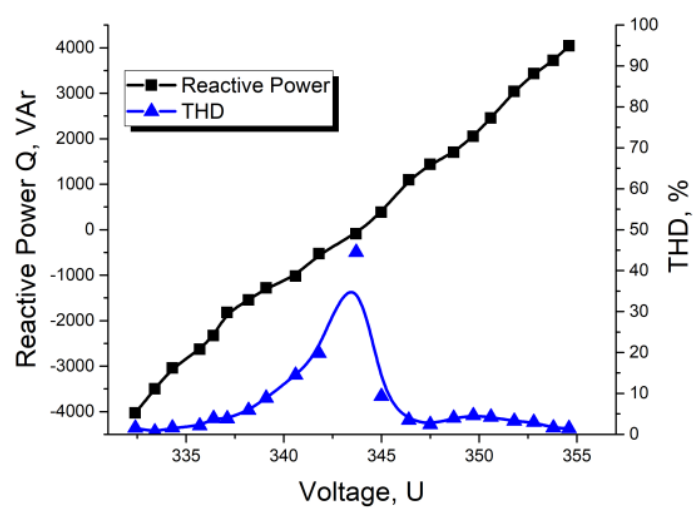

Fig. 2.4. The dependences of reactive power and THD on compensator output voltage $1^{\text {st }}$ harmonic amplitude 


\subsubsection{Cascaded Inverter based Single-Phase Compensator}

The cascaded inverters are mainly used in motor drives. In this work it is proposed to use the cascaded inverter for the reactive power compensation and the topology adapted for the implementation in inverter based compensator is proposed and investigated. The output voltage in the cascaded inverter topology is formed using two connected in series inverters (Fig. 1.3). This feature allows to provide the forming of voltage in two stages: first cascade operates with grid voltage frequency, i.e. at low switching frequency and second cascade works at high switching frequency. The idea of reactive power compensator current forming using the cascaded inverter is as follows: square wave formed by the first cascade consists not just of first harmonic wave but includes higher harmonic waves as well. The second cascade using PWM technique, operating at high frequency forms the waves of higher harmonics for the cancelation of harmonics generated by the first cascade. The amplitude of higher harmonic waves is significantly lower than the amplitude of main harmonic wave, therefore the second cascade can operate at relatively low voltage. The first cascade operates at higher voltage, which corresponds to the grid voltage. Since the operating frequency of first stage is low, the traditionally used IGBT transistors, that are characterized by relatively high internal resistance in state $\mathrm{ON}$ can be replaced with thyristor switches with low internal resistance. The low voltage high speed MOSFETs with low internal resistance in state $\mathrm{ON}$ and low switching losses can be employed in the second cascade.

Matlab/Simulink model of cascaded inverter based single-phase reactive power compensator and PWM signal controller are presented in Fig. 2.5.

Thyristors A1, A2, A3 and A4 are employed for main (grid voltage)) frequency and transistors B1, B2, B3 and B4 are implemented for THD correction using higher harmonics cancelation. PWM controller for forming of control signals for inverter switches (Fig. 2.5 (b)) consists of two separate PWM controllers: first for generation of control signals for thyristors of the first cascade, second one - for the MOSFETs of the second cascade. The first PWM controller sets the $50 \mathrm{~Hz}$ switching frequency for the first cascade, while the second one $-8 \mathrm{kHz}$ for the second cascade.

The proposed cascaded inverter based single-phase reactive power compensator provides voltage of seven levels at the output. The second cascade is employed only for elimination of higher harmonics, while first cascade provides voltage of single square pulse per cycle. Amplitudes of resultant voltage of the square voltage harmonics can obtained by solving Equation (Haykin \& Van Veen, 2003):

$$
A_{\mathrm{fN}}=\frac{2}{N \times A \times \pi \times\left(\sin \left(\frac{N \times n \times \pi}{2}\right)+\sin \left(N \times\left(\pi-\frac{n \times \pi}{2}\right)\right)\right)},
$$

where $N$-harmonic order, $A_{\mathrm{fN}}$ - amplitude of $N$-th order harmonic, $A$ - amplitude of square signal, $n$ - modulation index of square wave voltage. 


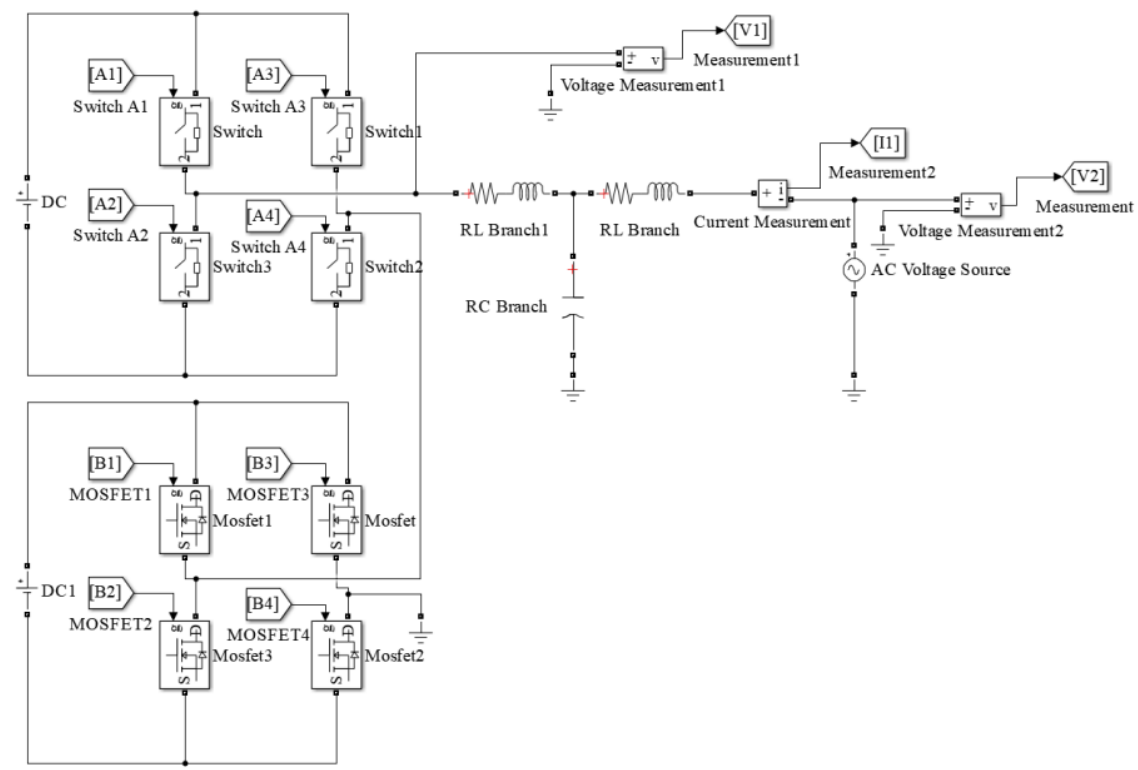

a)
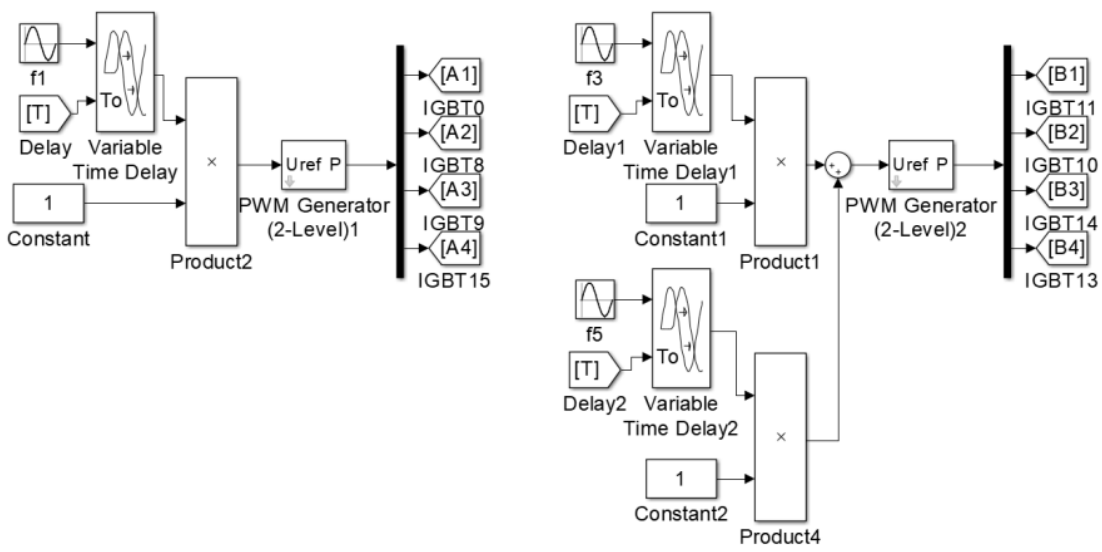

b)

Fig. 2.5. Matlab/Simulink model of cascaded inverter based single-phase reactive power compensator: a) model of compensator; b) model of pulse width modulation controller

Modulation index $n$ is proportional to output voltage amplitude. Maximal value of modulation index $n=1$, at which the compensator output voltage reaches its maximal value (2.1).

For the waveform presented in Fig. 2.6 a) Supply voltage of the first cascade is chosen $A=320 \mathrm{~V}$, equal to the amplitude of single-phase utility grid voltage. 
Amplitude of the thirst order harmonic of square voltage of $320 \mathrm{~V}$ at maximal modulation index $n=1$ is $A_{\mathrm{f} 1} \approx 407 \mathrm{~V}$, which is more than square signal amplitude, amplitude of the third harmonic $-A_{\mathrm{f} 3} \approx 136 \mathrm{~V}$. Therefore, supply voltage of $150 \mathrm{~V}$ for second cascaded inverter is sufficient for quality cancelation of current harmonics. Amplitude of all other higher order harmonics are lower than third harmonic amplitude and can be determined solving Equation (2.1).

For the development of proper harmonic elimination technique, simulation was performed. It was carried out when compensator operates as an inductive load and consumes $4 \mathrm{kVAar}$ of reactive power.

Firstly, the waveforms and spectrum of voltage and current for the square shape of voltage were investigated. The results are presented in Fig. 2.6. It is seen that square wave consists of sum of higher harmonics, which have to be eliminated in order to provide quality reactive power. For the checking of harmonic cancelation possibility, the PWM control signal for the switches of the second cascade was formed in such a way that the $3^{\text {rd }}\left(f_{3}=150 \mathrm{~Hz}\right)$ and $5^{\text {th }}\left(f_{5}=250 \mathrm{~Hz}\right)$ harmonics would be eliminated. Waveforms and spectrum of cascaded inverter output voltage and current with harmonic elimination are presented in Fig. 2.7.

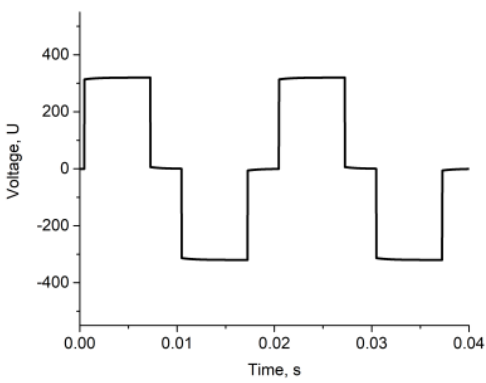

a)

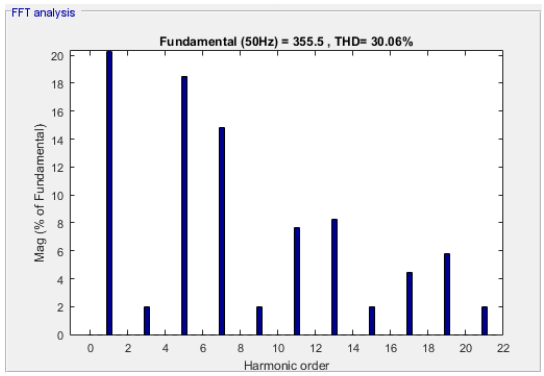

c)

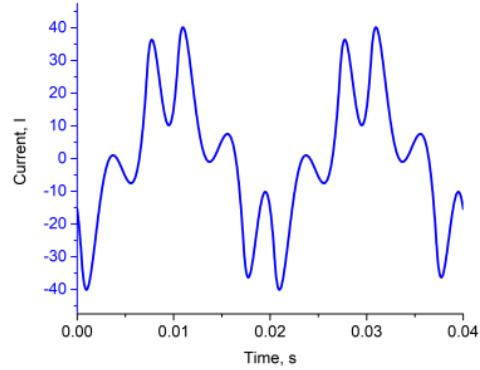

b)

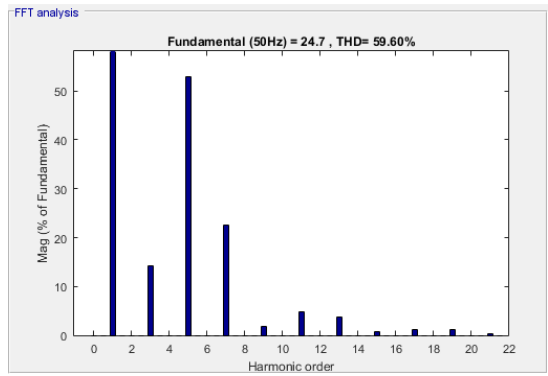

d)

Fig. 2.6. Waveforms and spectrums of inverter output voltage and current without harmonics cancelation: a) waveform of output voltage; b) waveform of output current; c) spectrum of output voltage; d) spectrum of output current 


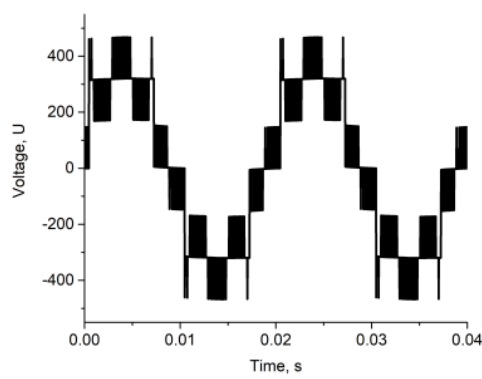

a)

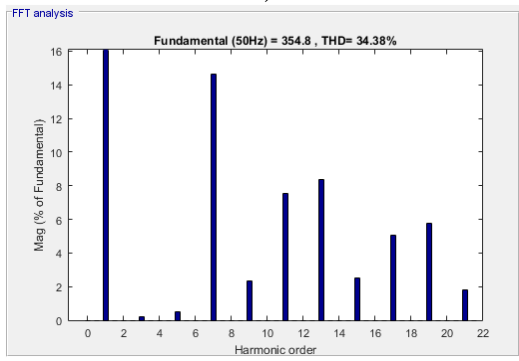

c)

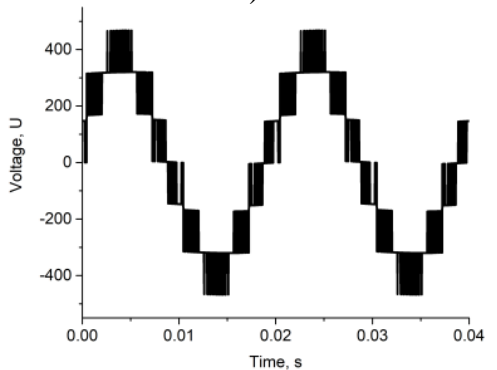

e)

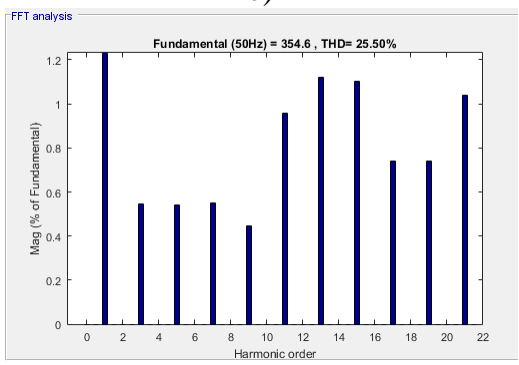

g)

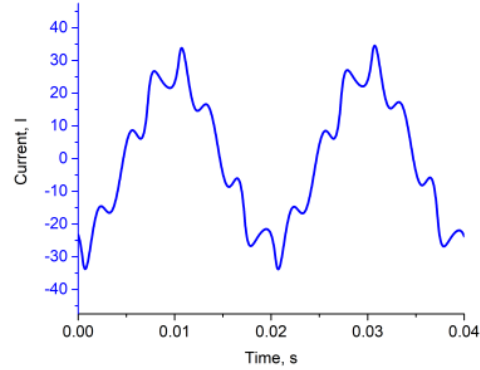

b)

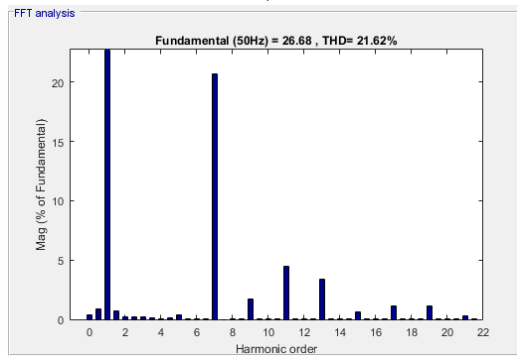

d)

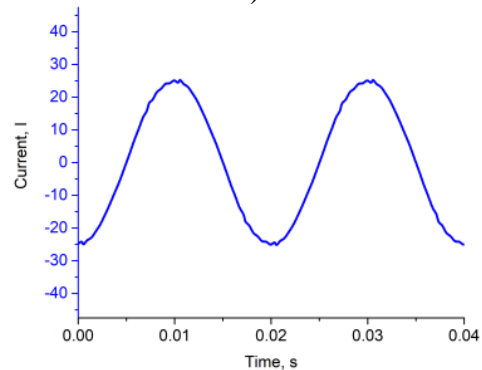

f)

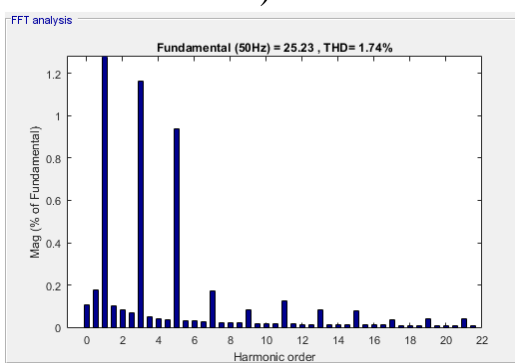

h)

Fig. 2.7. Waveforms and spectrums of inverter output voltage and current: a) output voltage; b) inverter current; c) spectrum of output voltage d) spectrum of inverter current with the cancelation of $3^{\text {rd }}$ and $5^{\text {th }}$ harmonics; e) output voltage; f) inverter current; g) spectrum of output voltage h) spectrum of inverter current with the cancelation of all harmonics up to $22^{\text {nd }}$ 
It is seen that the $3^{\text {rd }}$ and $5^{\text {th }}$ harmonics amplitudes in the spectrum of current became insignificant (Figs 2.7a-2.7d), i.e. the harmonics cancelation techniques can be applied in reactive power compensator. The elimination of $3^{\text {rd }}$ and $5^{\text {th }}$ harmonics allows to reduce the THD of current from 59.6\% to $21.62 \%$. The THD remains high because another harmonics are not canceled. During the next step, the cancelation up $22^{\text {nd }}$ harmonic, i.e. up to frequency $f_{22}=1100 \mathrm{~Hz}$ was carried out (Figs $2.7 \mathrm{e}-2.7 \mathrm{~h}$ ). It is seen that the cancelation up to the $22^{\text {nd }}$ harmonic allows reducing the THD up to $1.7 \%$ and the shape of the current is close to sinus.

Analyzed compensator can compensate capacitive and inductive reactive power up to $Q=4 \mathrm{kVAr}$. Waveforms of utility grid voltage and current, and spectrum of current are presented in Fig. 2.8. It is seen that supply current in Fig. 2.8 a) is capacitive and in Fig. 2.8 b) is inductive. The THD of the current when reactive power compensator acts as capacitive load is higher as compared to the case when it operates as inductive load (4.9\% and $1.7 \%$, respectively).

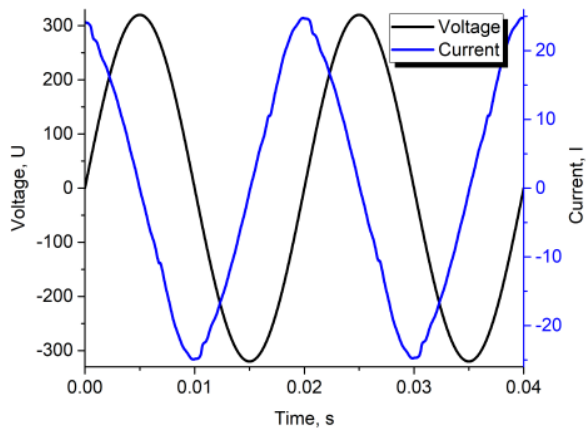

a)

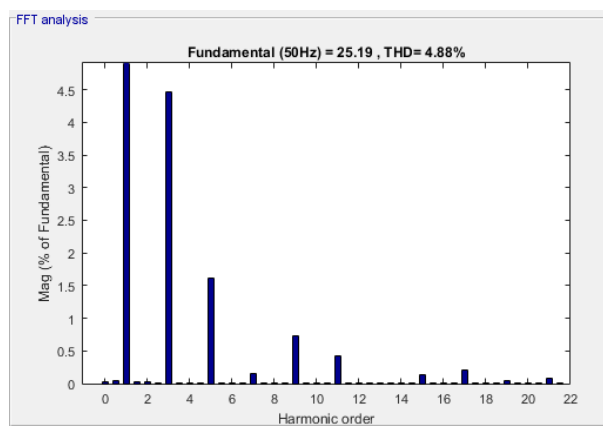

c)

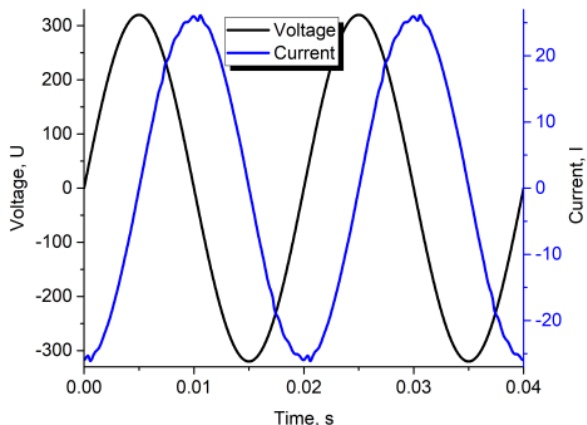

b)

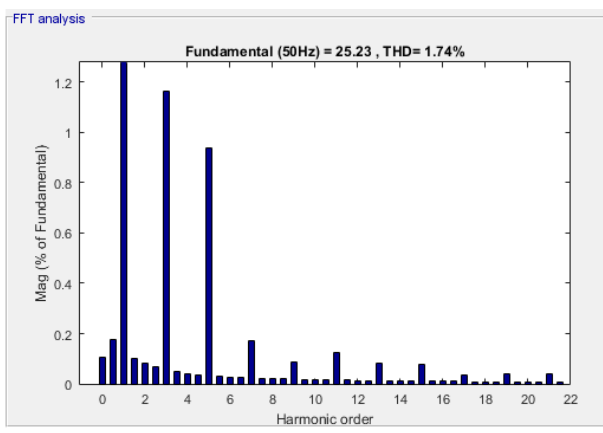

d)

Fig. 2.8. Waveforms and spectrums of compensator current with the cancelation of all harmonics up to $22^{\text {nd: }}$ a) waveform of inductive load current; b) waveform of capacitive current; c) spectrum of inductive current; d) spectrum of capacitive current 
The obtained relation between the reactive power produced or consumed by the compensator and THD is presented in Fig. 2.9. The value of reactive power consumed or produced by the compensator is varied by variation of compensator output voltage amplitude. It can be noticed that the highest THD value of is reached when the reactive power supplied by the compensator is minimal and it decreases when the absolute value of reactive power increases.

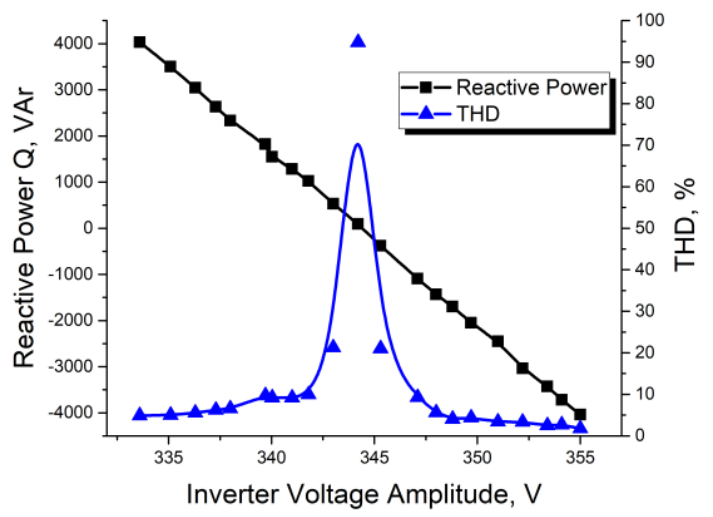

Fig. 2.9. The dependences of reactive power and THD on resultant inverter output voltage amplitude with the cancelation of all harmonics up to $22 \mathrm{nd}$

\subsection{Asymmetric Three-Phase Inverter based Reactive Power Compensator}

The asymmetric three-phase inverter based reactive power compensator based on the separate inverter for each phase has been proposed and investigated in this section. Two topologies of compensator have been proposed: compensator with the individual conventional inverters and compensator with the individual cascaded inverters for the every phase.

\subsubsection{Conventional Inverter based Reactive Power Compensator}

The widely used three-phase conventional inverter based compensator has been investigated in this chapter. The investigation purpose is to test if this compensator can provide asymmetric compensation of reactive power. The results obtained in this chapter will be required for comparative evaluation of the proposed compen- 
sators with the individual inverters for the every phase. The schematics of conventional three-phase inverter based reactive power compensator is presented in Fig. 2.10.

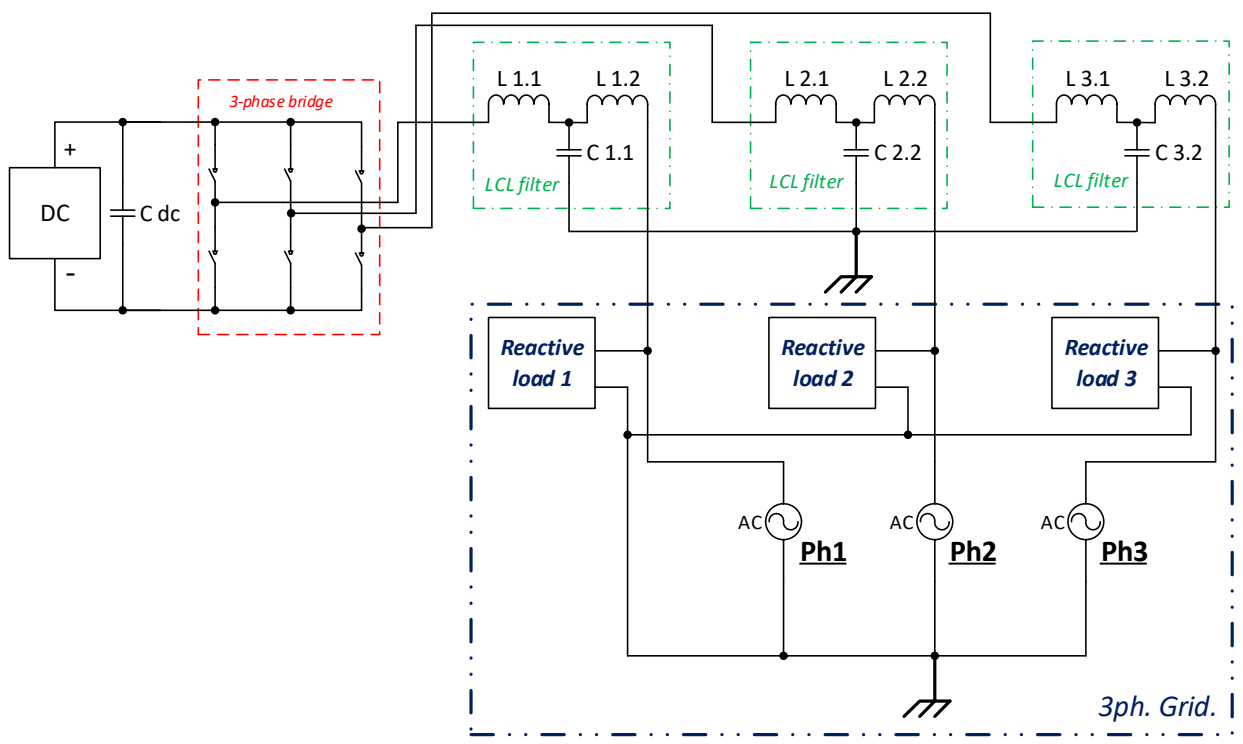

Fig. 2.10. Schematics of conventional three-phase inverter based reactive power compensator

The conventional three-phase inverter based reactive power compensator (Fig. 2.10) includes three leg inverter and output filters for each phase.

The Matlab/Simulink model of the conventional three-phase inverter based compensator was built for the investigation (Fig. 2.11). It consists of three-leg inverter connected to the utility grid employing low pass filters. For the evaluation of ability to control asymmetric reactive power at first the same amount of $2.2 \mathrm{kVAr}$ of reactive power was provided by the compensator to all phases, later at time moment $t=0.02 \mathrm{~s}$ the amount of reactive power supplied by the compensator to the first phase was instantaneously increased up to $4.5 \mathrm{kVAr}$. The transients of reactive power are presented in Fig. 2.12. It is seen that change of reactive power supplied by the first phase influence the reactive power provided by the second and third phases. Finally, at time moment $t=0.3 \mathrm{~s}$, all phases of the compensator provided the same $3.5 \mathrm{kVAr}$ of reactive power in spite the fact that the reactive power of the first phase was set to $4.5 \mathrm{kVAr}$, the reactive power 
of second and third phases to $2.2 \mathrm{kVAr}$. Therefore, the obtained investigation results of conventional three-phase inverter based compensator show that it is incapable of asymmetric reactive power compensation.

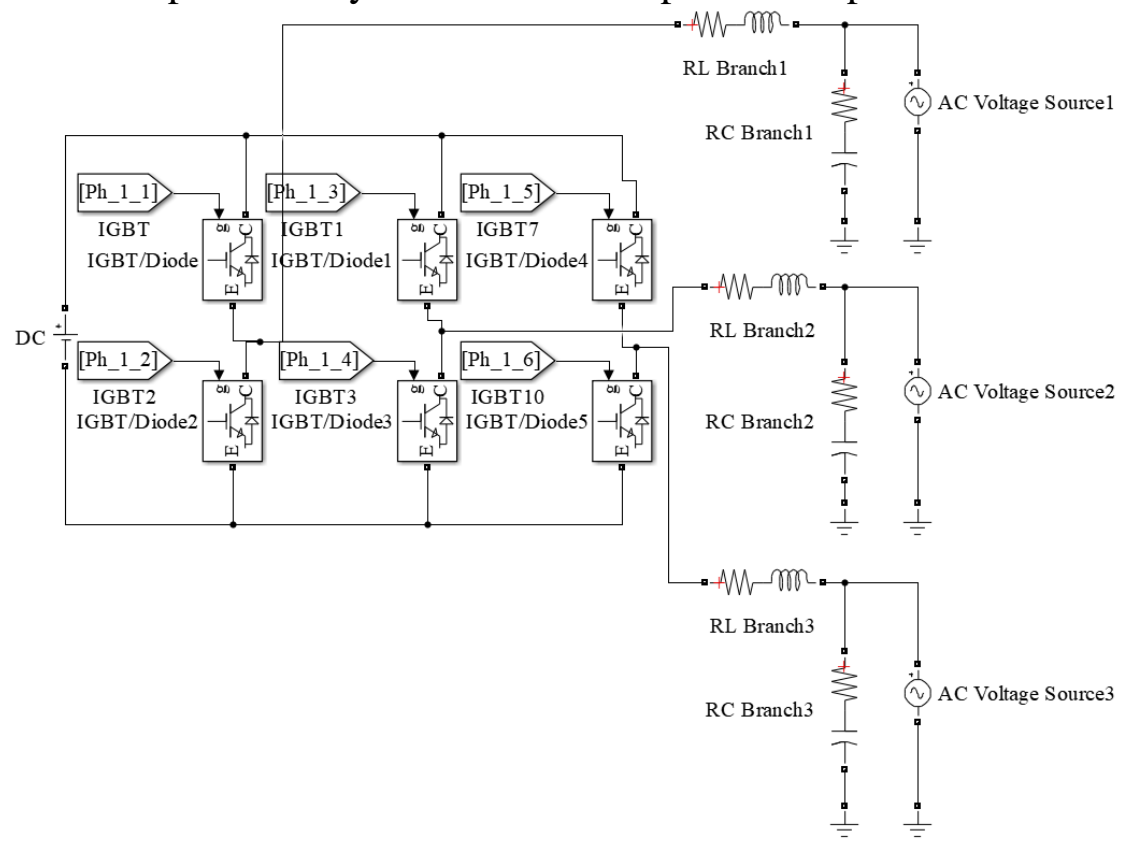

Fig. 2.11. Matlab/Simulink model of conventional inverter based reactive power compensator

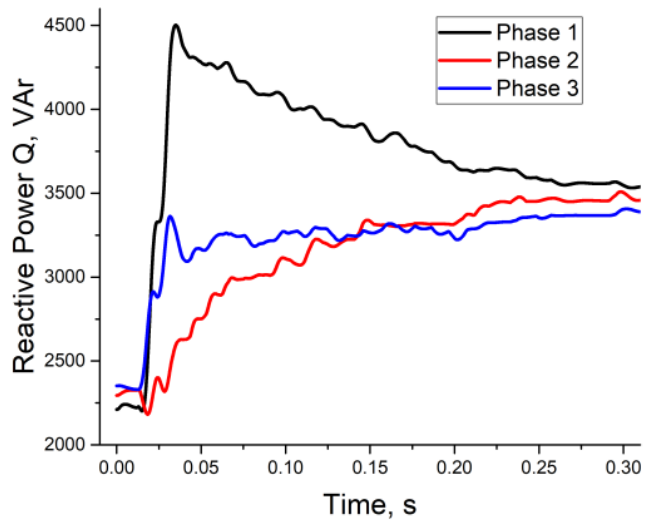

Fig. 2.12. Transients of reactive power set point step response of conventional inverter-based reactive power compensator 


\subsubsection{Asymmetric Reactive Power Compensator with the Individual Inverters for the Every Phase}

Conventional inverter topology is employed for numerous power electronics applications including inverter based reactive power compensators. (Neves et al., 2009; Rozanov et al., 2016). Never less there are no three-phase asymmetric reactive power compensation approaches employing conventional inverter for each phase. Schematics of the proposed asymmetric reactive power compensator with the individual conventional inverters for the every phase is presented in Fig. 2.13. This approach consists of three independent single-phase conventional inverters connected in star with neutral. Matlab/Simulink model developed in Section 2.1.1 was employed for the simulation of this compensator.

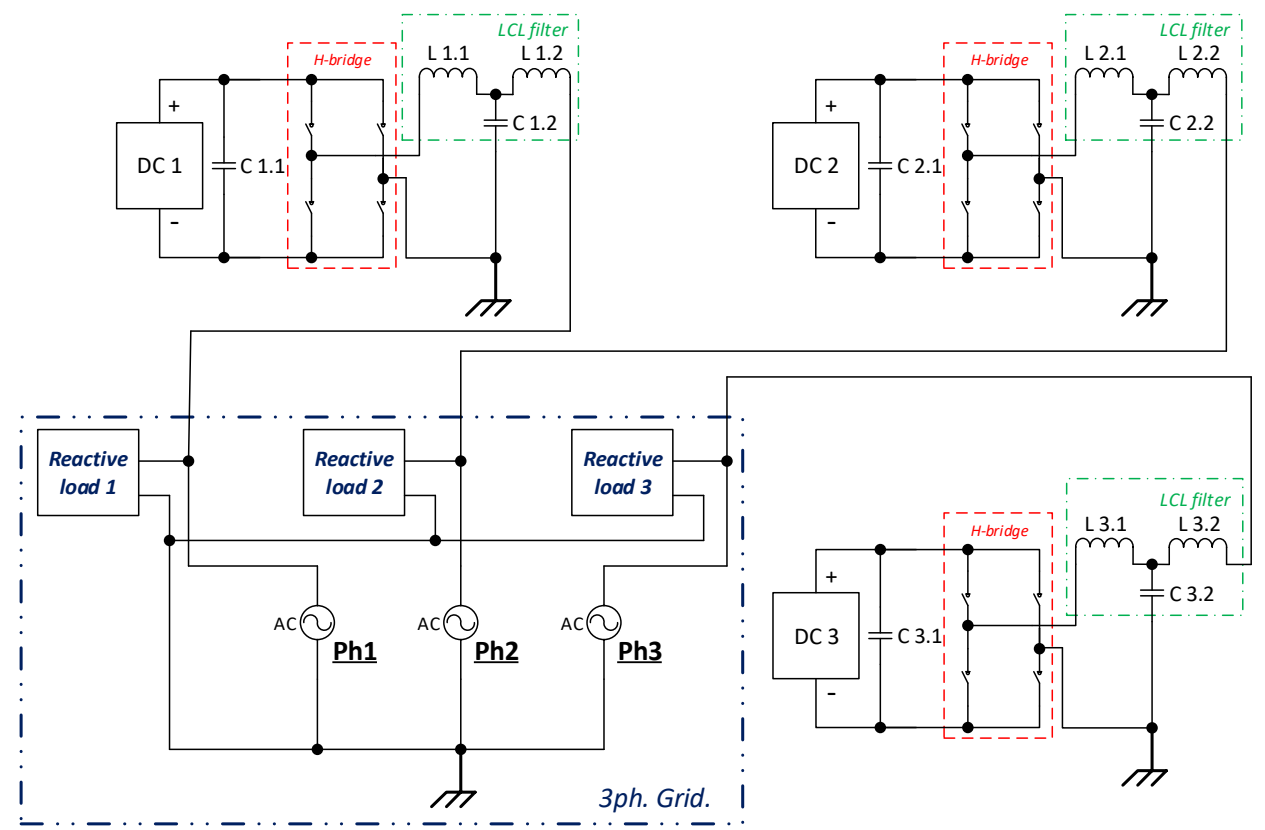

Fig. 2.13. Schematics of asymmetric reactive power compensator with the individual conventional inverters for the every phase

Another proposed approach was employing cascaded inverter topology for the development of compensator with the individual single phase inverters. In this case each cascade is supplied with isolated voltage source and is capable of providing 7 level output voltage. In order to reduce switching losses majority of power is being produced by one cascade at low frequency while second cascade performs harmonic elimination at low power at high frequency. Schematics of 
asymmetric reactive power compensator with the individual cascaded inverters for the every phase is presented in Fig. 2.14.
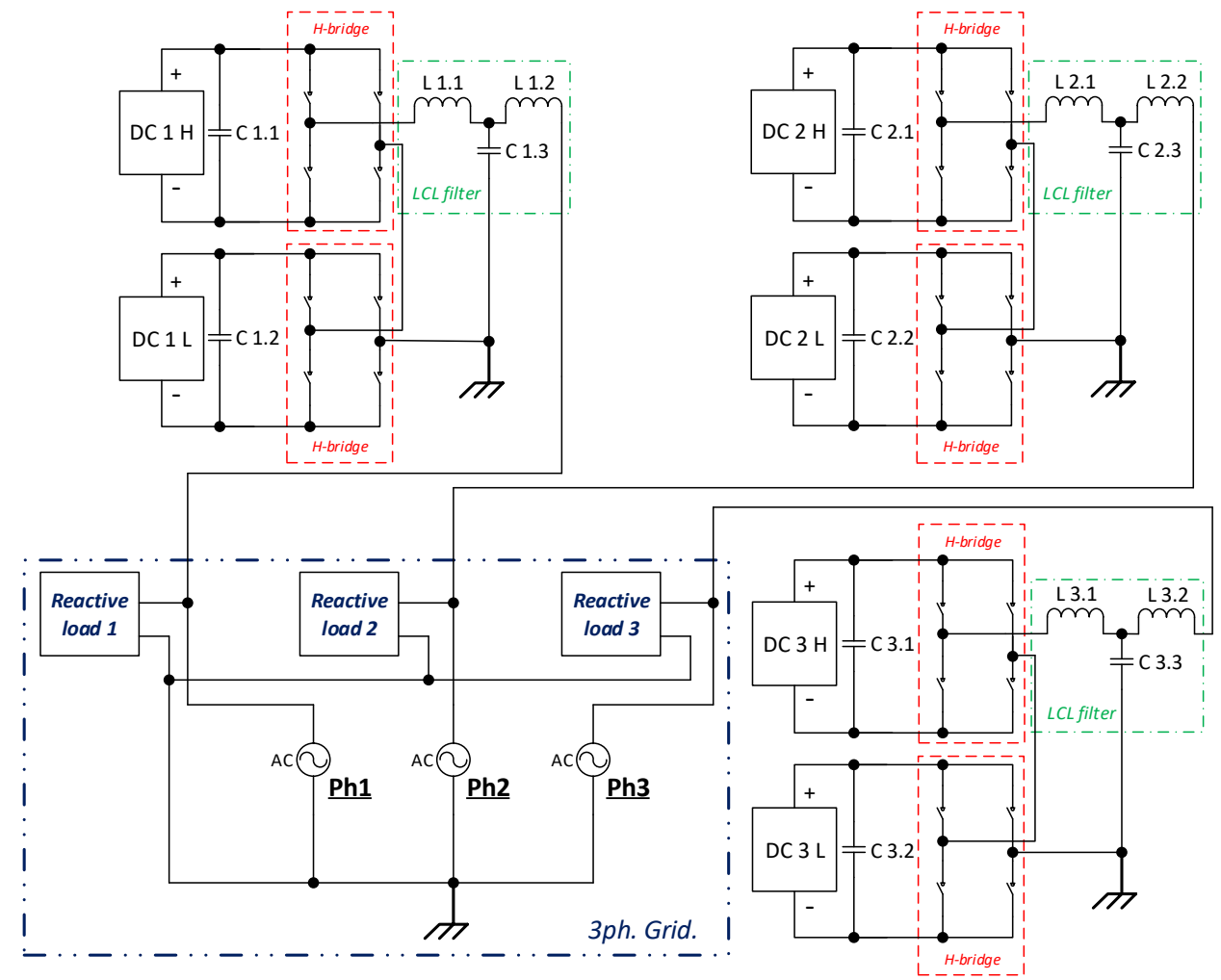

Fig. 2.14. Schematics of asymmetric reactive power compensator with the individual cascaded inverters for the every phase

For the testing of asymmetric reactive power compensation capability, simulation of two proposed topologies was carried out. During this simulation at first, compensators are switched off and there is now reactive power in the utility grid. Later one by one different reactive loads are applied for each phase: $-4.4 \mathrm{kVAr}$ to first phase; $2.0 \mathrm{kVAr}$ to second phase; $3.0 \mathrm{kVAr}$ to third phase. Compensators are set to start reactive power compensation at time moment $t=0.04 \mathrm{~s}$ after reactive load was applied. Compensation transients of reactive power of each phase for both topologies are presented in Fig. 2.15. It can be observed that reactive power compensation in any phase has no impact on reactive power in any other phase. The settling time during which the reactive power is compensated is in range $0.12-0.22 \mathrm{~s}$. 


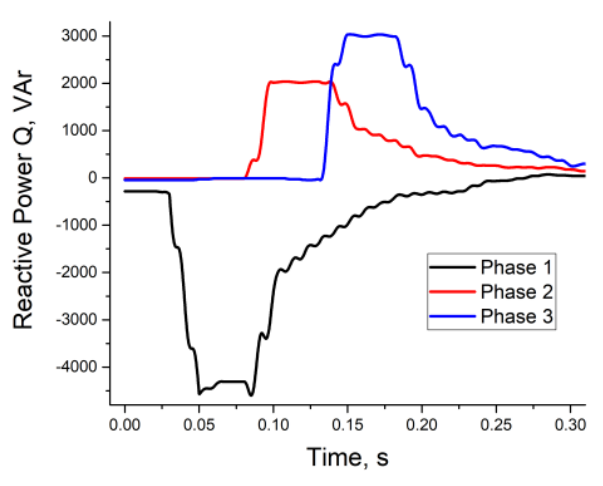

a)

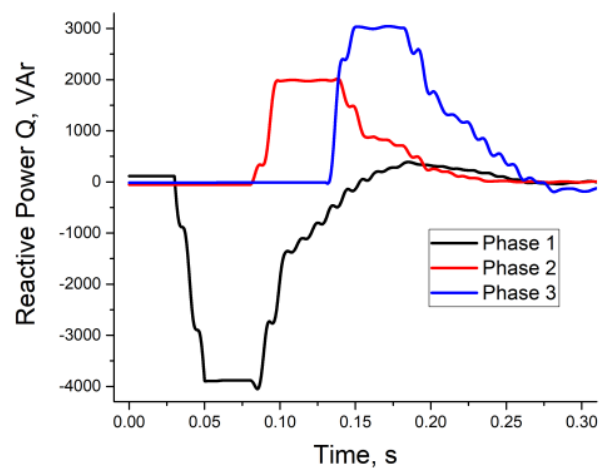

b)

Fig. 2.15. Transient of reactive power compensation for each phase: a) transients of inverter-based compensator with the individual inverters for the every phase; b) transients of cascaded inverter-based compensator with the individual inverters for the every phase

As reactive power that is necessary to compensate is different in the every phase it can be concluded that both proposed three-phase asymmetric inverter based reactive power compensators are suitable for asymmetric reactive power compensation.

\subsection{Conclusions of Chapter 2}

1. The adapting of cascaded inverter topology for the development of reactive power compensator allows to provide the forming of voltage using two cascades: first cascade operates with grid voltage frequency, i.e. at low switching frequency and can be implemented using thyristors, the second one works at high switching frequency and can be designed using low voltage high speed MOSFETs.

2. The developed cancelation technique of higher harmonics of the cascaded inverter based reactive power compensator current allows to reach the $1.7 \%$ value of current THD when all harmonics up to the 22nd order are eliminated.

3. All phases of the conventional inverter based compensator provided the same $3.5 \mathrm{kVAr}$ of reactive power in spite the fact that the reactive power of the first phase was set to $4.5 \mathrm{kVAr}$, the reactive power of second and third phases to $2.2 \mathrm{kVAr}$. Therefore, it can be stated that conventional three-phase inverter based compensator is incapable of asymmetric reactive power compensation. 
4. The proposed compensators with the individual inverters for the every phase with neutral connection are capable to provide asymmetric compensation of reactive power in the low voltage utility grid because the reactive power provided by any phase of the compensator has no impact on reactive power in any other phase.

5. The settling time during which the reactive power is compensated using compensators with the individual inverters for the every phase is in range $0.12-0.22 \mathrm{~s}$. 


\section{Asymmetric Shunt-Connected Reactive Power Compensator}

This chapter presents the results of development and investigation of shunt-connected compensator for smooth asymmetric compensation of reactive power in low voltage utility grid. The investigation of proposed compensator was performed experimentally using developed experimental test bench. The obtained results have been published in two publications (Šapurov, Bielskis, et al., 2020; Šapurov, Bleizgys, et al., 2020).

\subsection{Principle of the Smooth Shunt-Connected Reactive Power Compensator}

Firstly, the symmetric shunt-connected reactive power compensator research was carried out in order to validate the possibility of this approach implementation in the low voltage utility grid Block diagram of the developed smooth reactive power compensator is presented in Fig. 3.1. It consists of the conventional reactive power compensator, build from capacitor banks, electromechanical relays for capacitor bank commutation to the utility grid and a designed reactor for smooth compensation capabilities. 


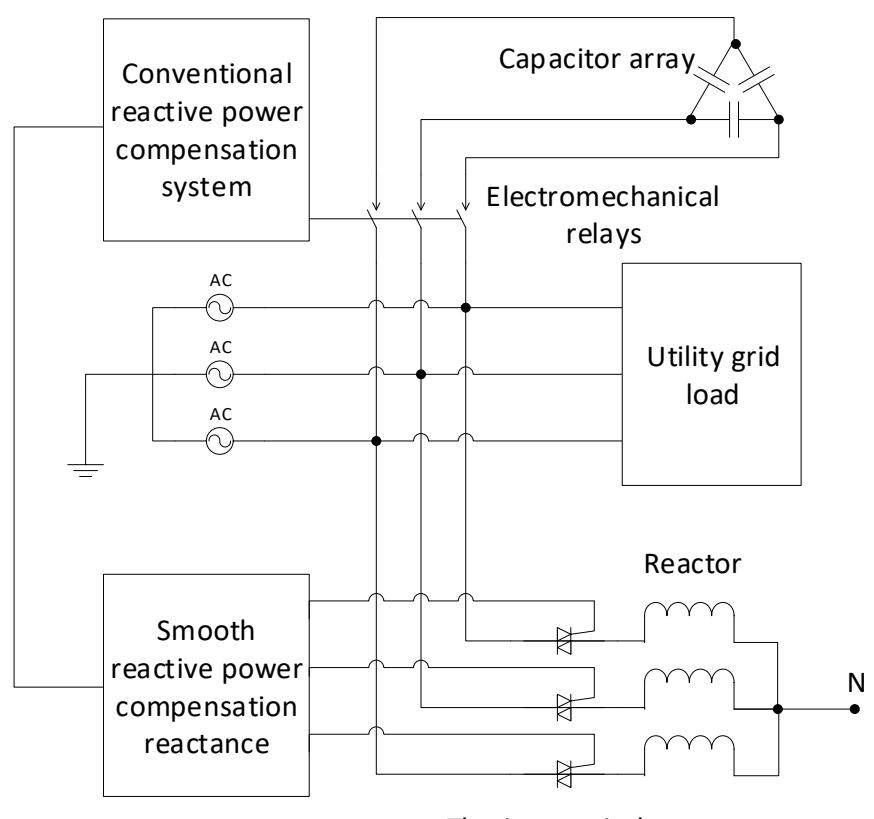

Thyristor switches

Fig. 3.1. Block diagram of a smooth symmetric reactive power shunt-connected compensator

The conventional compensator is incapable of full reactive power compensation; therefore the parallel-connected smooth reactive power compensator, built of thyristor-controlled inductances (reactors) is introduced. In this application, the reactive power is being overcompensated employing conventional compensator; therefore, the utility grid load becomes capacitive. Introducing thyristor-controlled reactor allows smooth cancelation of the capacitive load by providing the inductive load to the utility grid. For the smooth inductive load variation, thyristor switches are being employed, the load is controlled by variation of the thyristor switches gating angle from $\alpha=90^{\circ}$ to $\alpha=180^{\circ}$.

\subsection{Matlab/Simulink Simulation of Shunt-Connected Reactive Power Compensator}

Prior to experimental research the simulation of proposed system was carried out. The main goal of simulation was to develop a proper control technique for the 
reactor in the low voltage utility grid and to determine accurate reactor parameters. Reactive power compensated by the developed system was set to $Q=10$ $20 \mathrm{kVAr}$. For the three phase utility grid using Y connection, consumed reactive power is calculated by equation:

$$
Q=\sqrt{3} U I \sin \varphi,
$$

where $U$ is phase voltage magnitude, $I$ - phase current, $\varphi$ - phase angle of voltage vector to current vector.

Consumption of active power should be excluded in developed system; therefore, it could be assumed that compensator consumes only reactive power. In such case $\varphi \approx 90^{\circ}, \sin \varphi \approx 1$. Ohm's Law for alternating current circuits could be applied to Equation (3.1):

$$
I=\frac{\sqrt{3} U}{X_{L}} .
$$

The new expression of (3.1) could be achieved:

$$
Q=\frac{3 U^{2}}{X_{L}}
$$

where $X_{L}=\omega L$ stands for reactive impendance, $L-$ reactor inductance, $\omega=2 \pi f$ - angular frequency of voltage fundamental waveform.

By applying $X_{L}$ expression, new equation could be achieved:

$$
\mathrm{Q}=\frac{3 U^{2}}{\omega L} \text {. }
$$

According to the task of the research consumed reactive power should be $=$ $12 \mathrm{kVAr}=12000 \mathrm{VAr}$, utility grid voltage frequency $f=50 \mathrm{~Hz}$, therefore:

$$
L=\frac{3 \cdot 230^{2}}{2 \cdot 3,14 \cdot 50 \cdot 12 \cdot 10^{3}}=0.042 \mathrm{H} \approx 40 \mathrm{mH} .
$$

Desired efficiency of developed system should be $\eta \geq 0.95$ i.e. active power consumption of developed compensator $P \leq 0.95 Q$. Active and reactive power of reactor depends on active and reactive impedance components. Matlab/Simulink thyristor controlled reactor model and simulation results are presented in Fig. 3.2.

Matlab/Simulink model presented in Fig. 3.2, (a) consists of: modelling time constant $T_{\mathrm{s}}=2 \cdot 10^{-5} \mathrm{~s}$, voltage source AC $(U=230 \mathrm{~V}, f=50 \mathrm{~Hz})$, phase current and voltage measuring devices, measurement unit for active and reactive power consumption $(P=194 \mathrm{~W}, Q=4.07 \mathrm{kVAr})$, reactor $(R=0.5 \Omega, L=$ $40 \mathrm{mH})$ and osciloscope. 


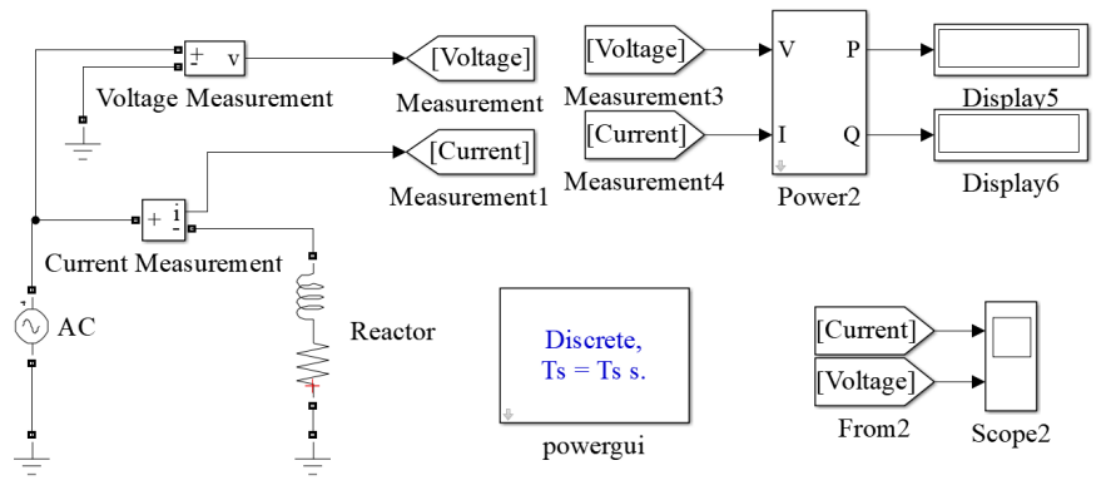

a)

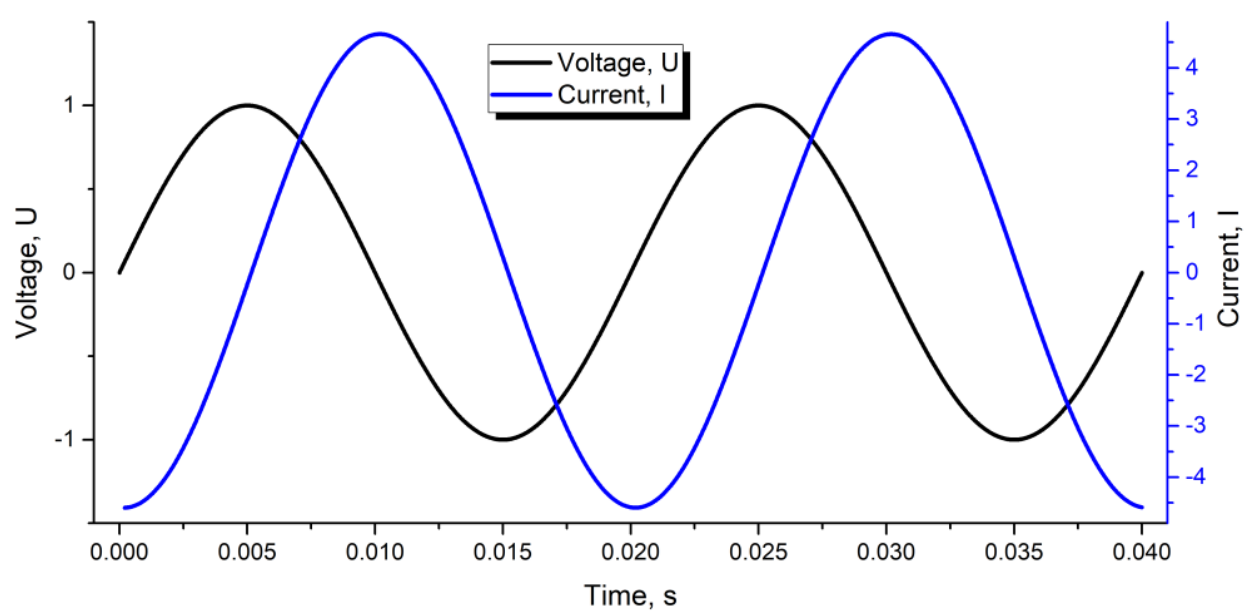

b)

Fig. 3.2. Matlab/Simulink model and waveforms of voltage and current of the thyristor controlled reactor: a) model of thyristor controlled reactor; b) waveforms of voltage and current of thyristor controlled reactor

Active power $P$ to reactive power $Q$ consumption ratio achieved in the process of modeling is $\frac{P}{Q}=\frac{194.1}{4065}=0.047 \leq 0.05$, whitch corresponds to system requirements. In Fig. 3.2 (b) it could be observed that the phase of current is delayed to phase of voltage by $\sim 90^{\circ}$, therefore the load is completely of the reactive type, $\sin \varphi \approx 1$.

Thyristor controlled reactor reactance is controlled by variation of firing angle $\alpha$ in $90-180^{\circ}$ (Khonde \& Palandurkar, 2014; Mahapatra et al., 2014). The 
Matlab/Simulink single-phase shunt connected reactive power compensator was developed (Fig. 3.3), simulation results are presented in Fig. 3.4.
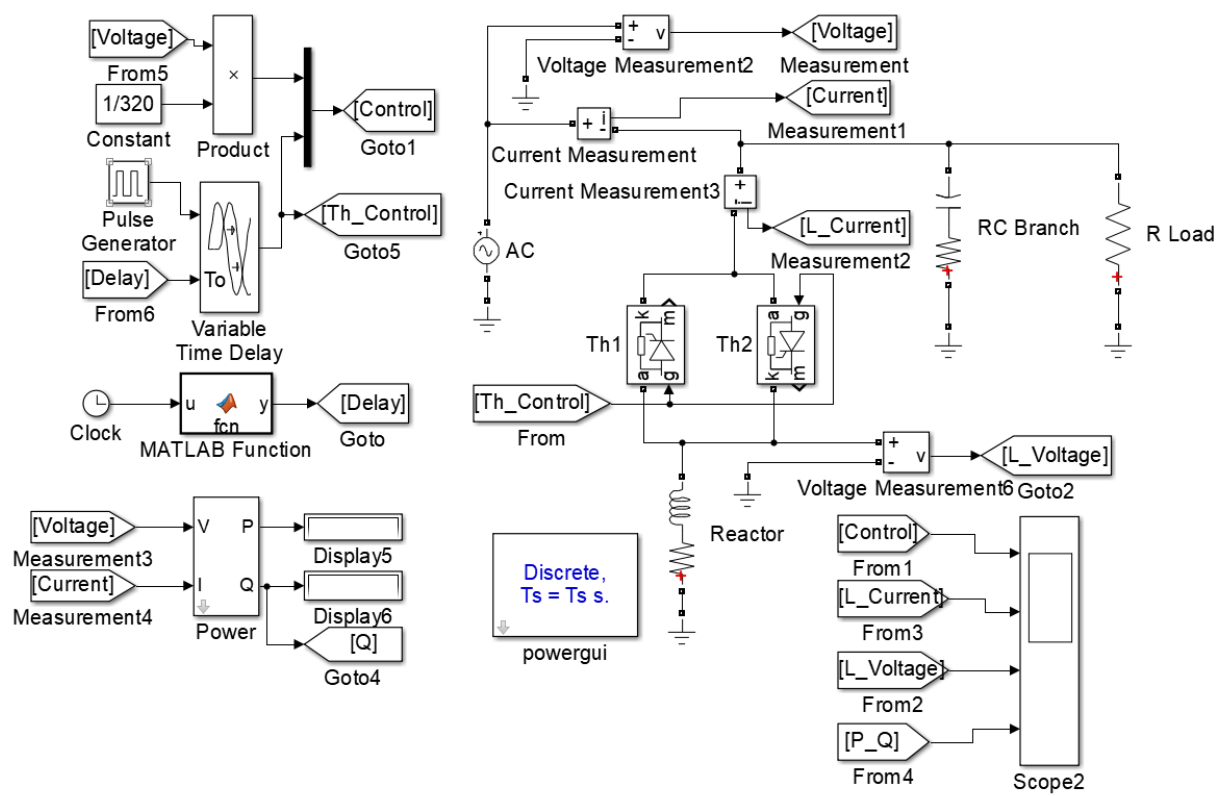

Fig. 3.3. Matlab/Simulink model of single-phase shunt-connected reactive power compensator

Matlab/Simulink model presented in Fig. 3.3 consists of: a modelling time constant $T_{\mathrm{s}}=2 \cdot 10^{-5} \mathrm{~s}$, voltage source AC $(U=230 \mathrm{~V}, f=50 \mathrm{~Hz})$, phase current and voltage measuring devices, a measurement unit for the active and reactive power consumption $(P=194 \mathrm{~W}, Q=4.07 \mathrm{kVAr})$, reactor $(R=0.5 \Omega, L=$ $40 \mathrm{mH}$ ) and a zero crossing detector, a variable delay circuit for firing angle control, a mathematical delay module, thyristors and an oscilloscope. It could be observed in Fig. 3.4 (a) that by variation of voltage to current phase angle $\alpha$ from $180^{\circ}$ to $90^{\circ}$, the reactive power consumption is being continuously increased upon a nominal value $Q_{\mathrm{f}}=\frac{Q}{3} \approx 4 \mathrm{kVAr}$ is being reached.

There are two main high power switch topologies, which could be employed for reactor connection to the utility grid. There could be used thyristor switches as in Fig. 3.3, hence MOSFET switches could be used as well. Matlab/Simulink model for MOSFET switch single-phase reactive power compensator topology is presented in Fig. 3.5. 


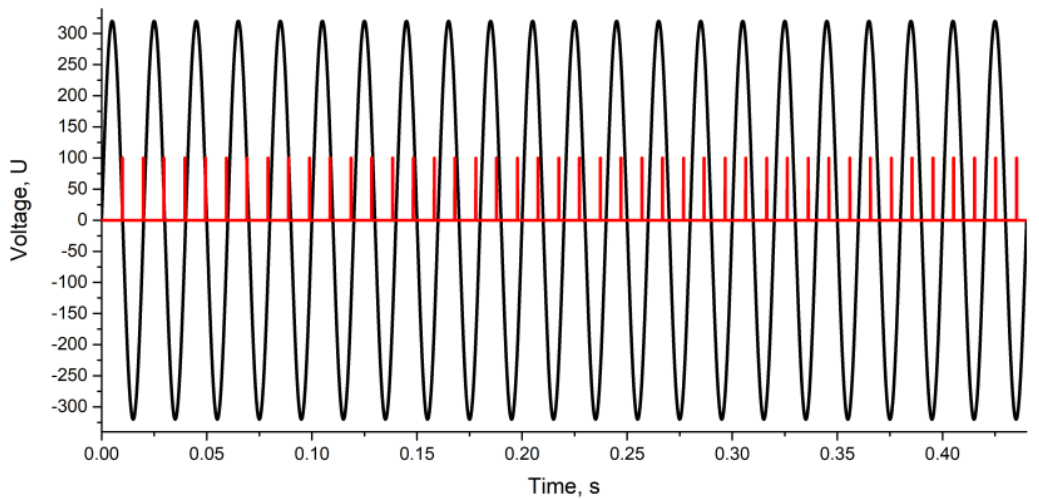

a)

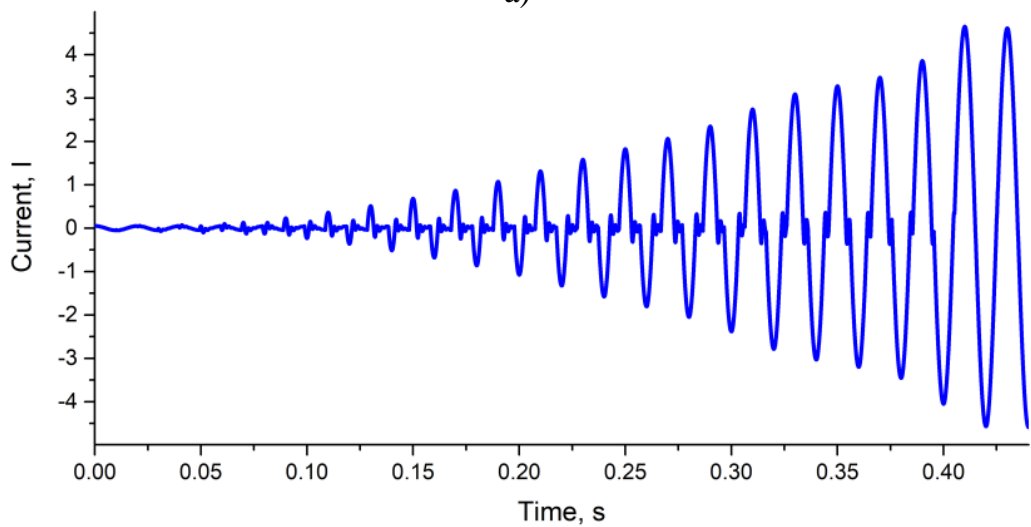

b)

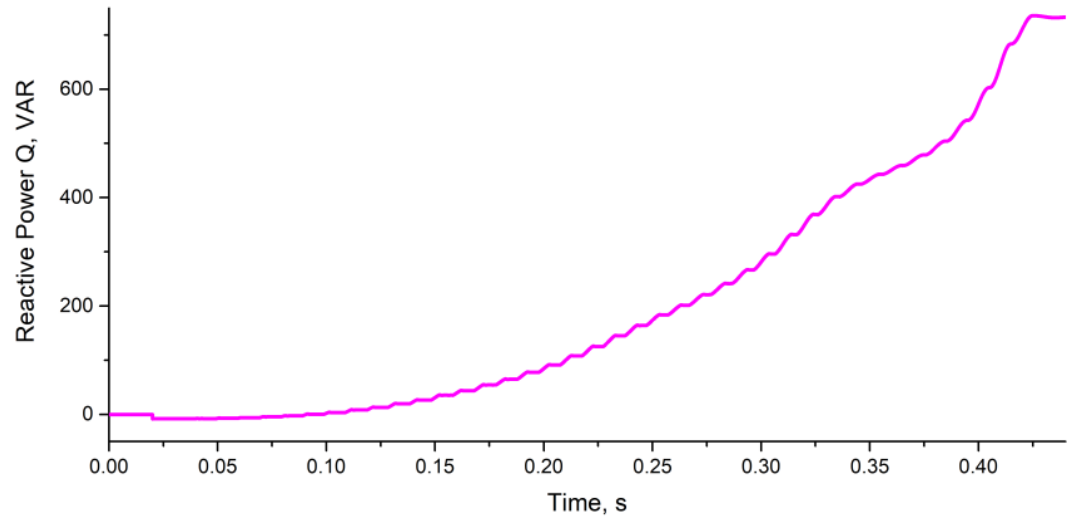

c)

Fig. 3.4. Waveforms of thyristor controlled reactor: a) voltage (in black) and control signal (in red); b) current; c) reactive power 


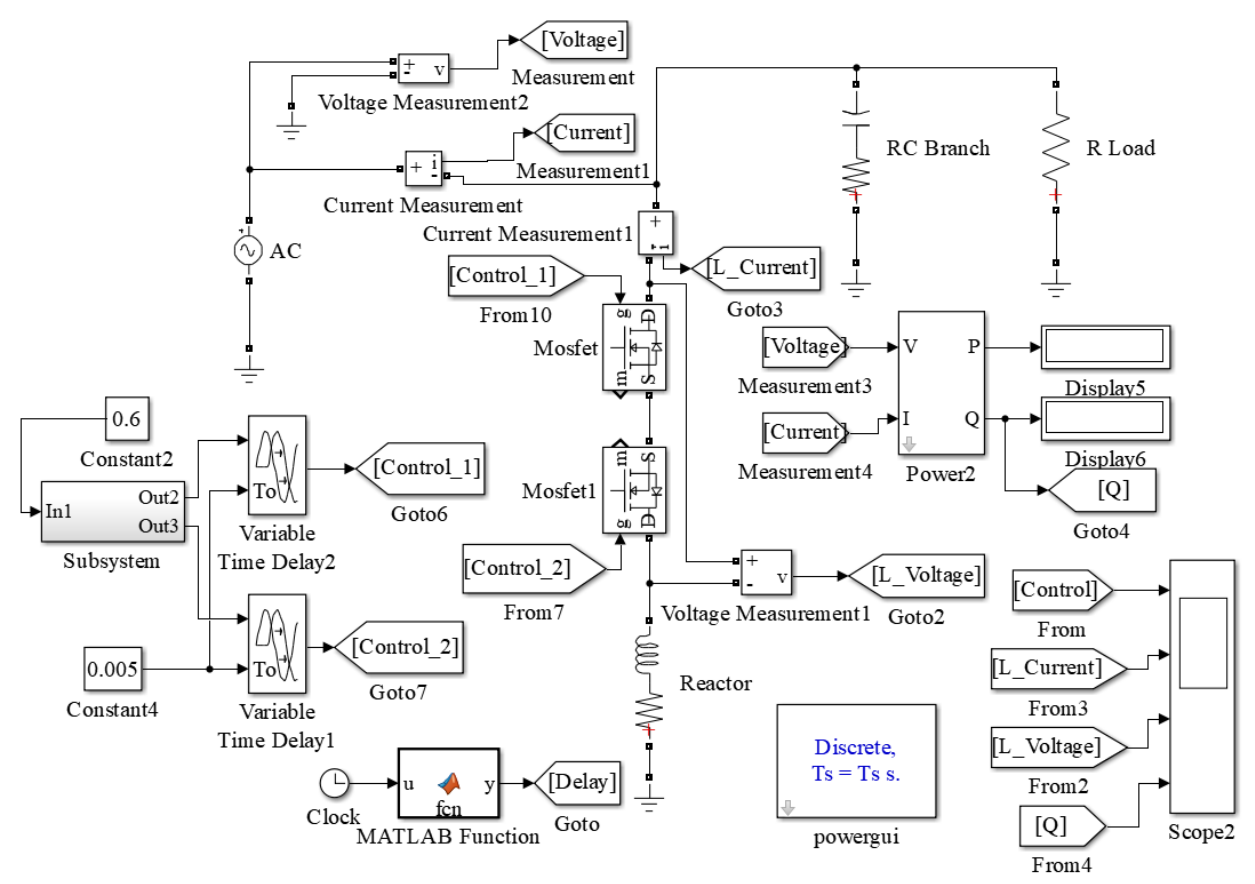

Fig. 3.5. Matlab/Simulink model of MOSFET switch topology of single-phase shunt-connected reactive power compensator

Matlab/Simulink model presented in Fig. 3.5 consists of: modelling time constant $T_{\mathrm{s}}=2 \cdot 10^{-5} \mathrm{~s}$, voltage source AC $(U=230 \mathrm{~V}, f=50 \mathrm{~Hz})$, phase current and voltage measuring devices, measurement unit for active and reactive power consumption $(P=194 \mathrm{~W}, Q=4.07 \mathrm{kVAr})$, reactor $(R=0.5 \Omega, L=40 \mathrm{mH})$ and control signal generation circuit, MOSFET switch and oscilloscope. Simulation results of MOSFET switches topology is presented in Fig. 3.6. It could be observed in Fig. 3.6 a) that for this implementation it necessary to control not only switch opening, but also closing timing.

It can be noticed in Fig. 3.6 b) that voltage overshoots appear at cut of in case it is executed on exactly at zero crossing time of current. In consideration of control technique complicity and voltage, overshoots appearing due to timing maintaining problems the thyristor switch topology was chosen for further shunt connected reactive-power compensator development. 


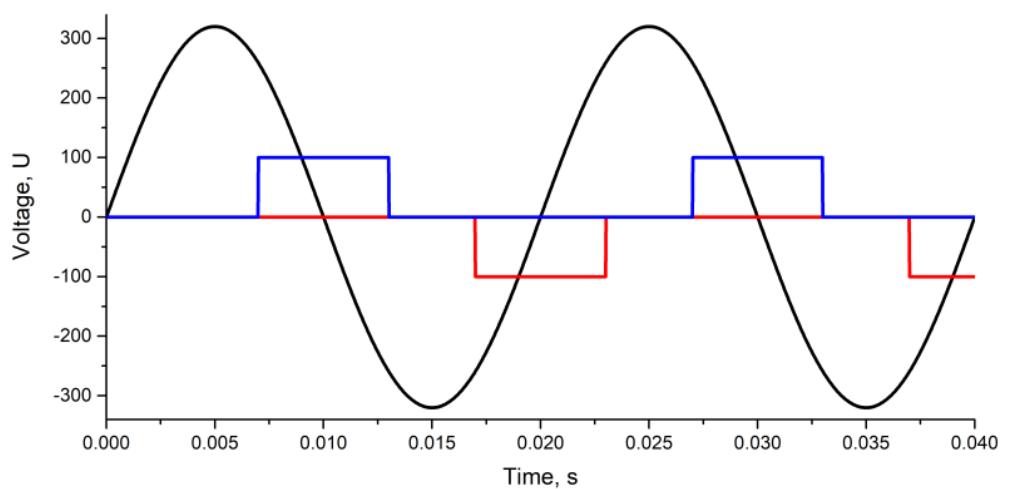

a)

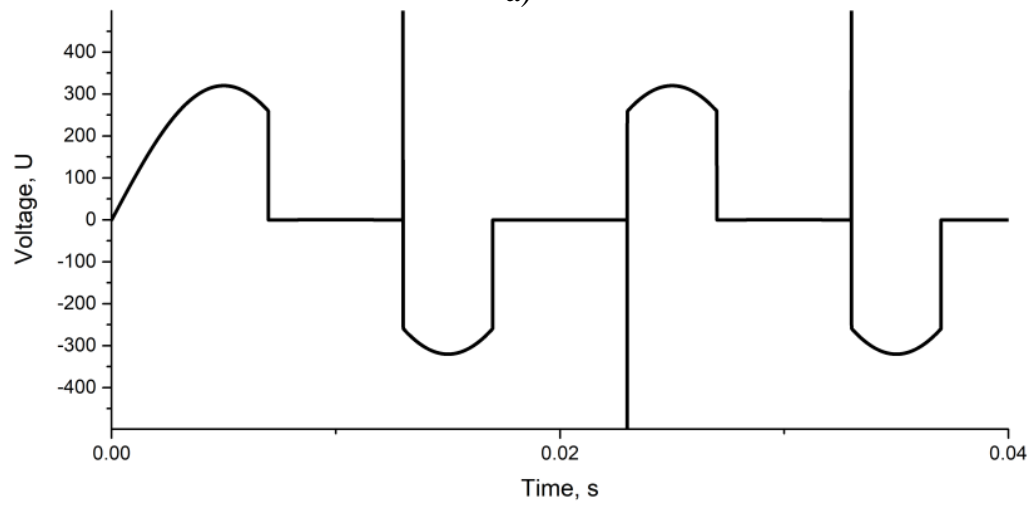

b)

Fig. 3.6. Waveforms MOSFET controlled reactor: a) voltage (in black) and control signal (in red and blue); b) MOSFET voltage overshoots when switch turn off timing does not correspond to current zero crossing point

For three phase applications, inductance could be connected in $\mathrm{Y}$ or $\Delta$. For evaluation purposes Matlab/Simulink model of $\Delta$ connected tree-phase reactive power compensator is presented in Fig. 3.7. Waveform and spectrum of $\Delta$ connected tree-phase reactive power compensator is presented current is presented in Fig. 3.8.

It can be observed in Fig. 3.8 that current of $\Delta$ connected reactive power compensator can be successfully controlled by variation of firing angle. Never less for $\Delta$ connection reactive power is compensated at two phases simultaneously, what makes asymmetric compensation impossible. For asymmetric compensation Matlab/Simulink model of Y connected three-phase reactive power compensator with neutral was developed (Fig. 3.10). Waveform and spectrum of Y connected tree-phase reactive power compensator with neutral is presented current is presented in Fig. 3.9. 


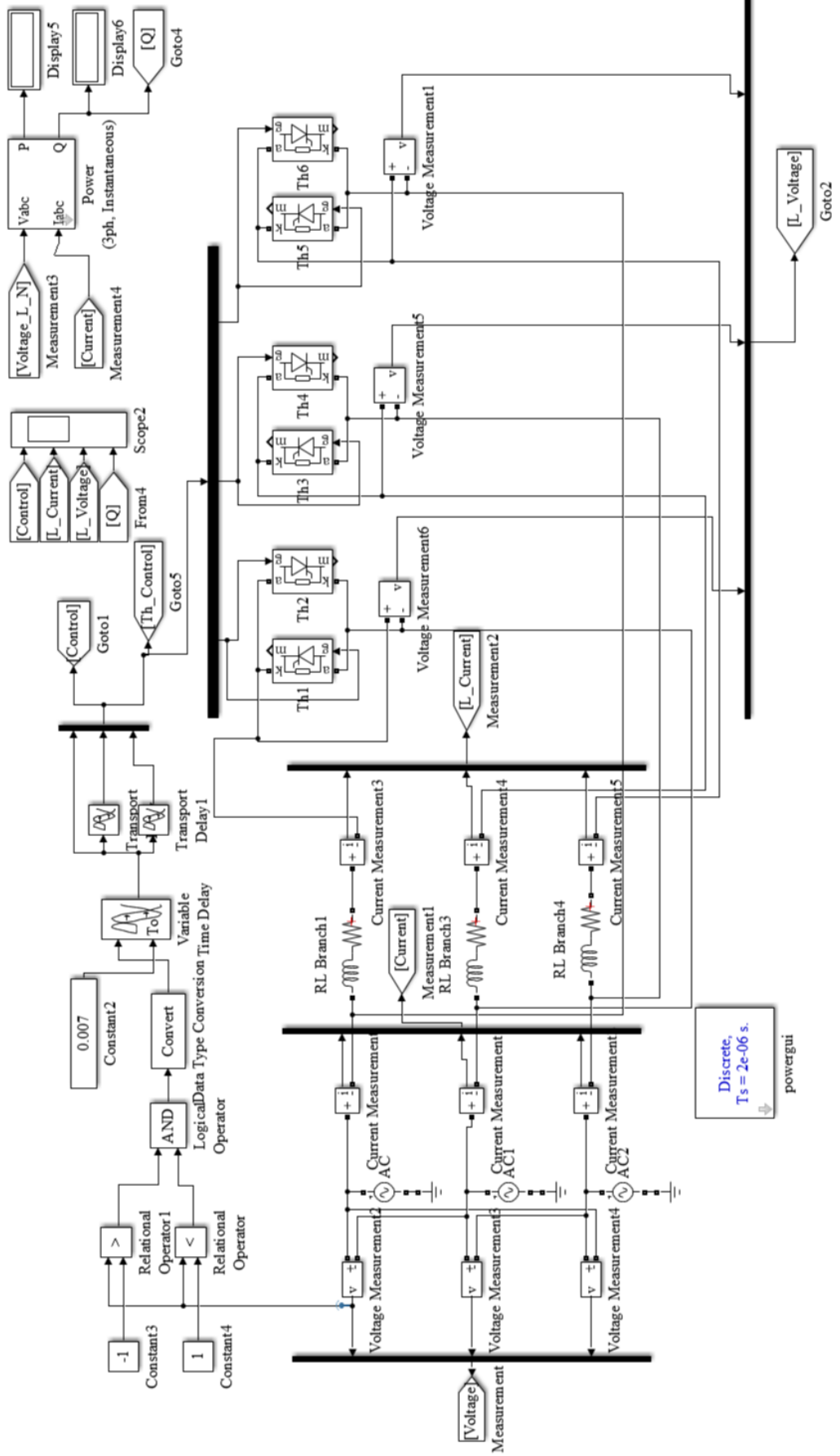

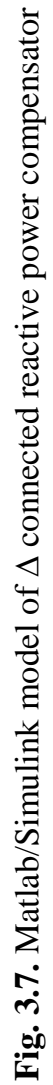



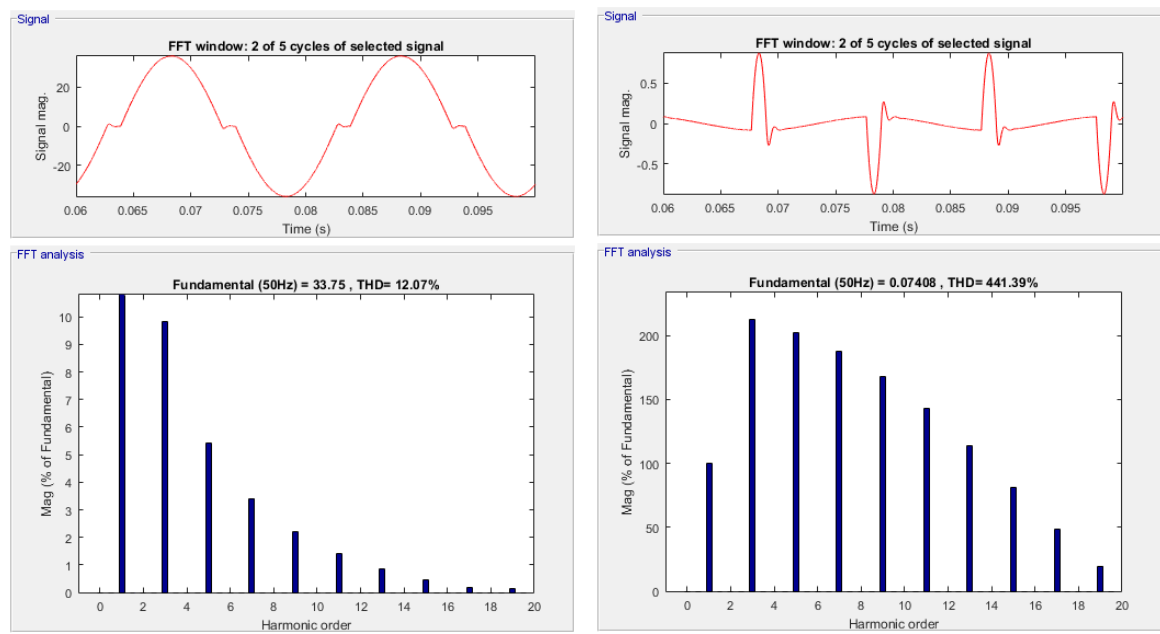

a)

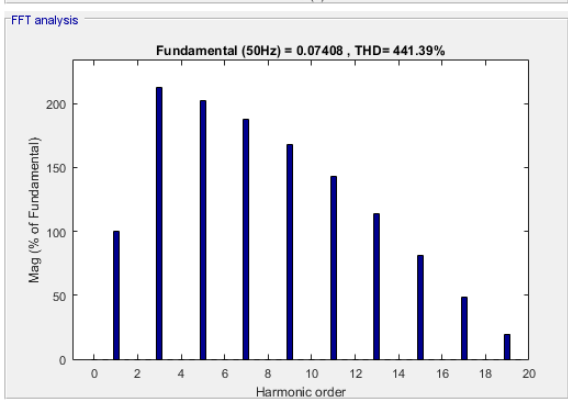

b)

Fig. 3.8. Waveform and spectrum of delta connected reactive power compensator current at firing angles: a) $100^{\circ}$; b) $168^{\circ}$

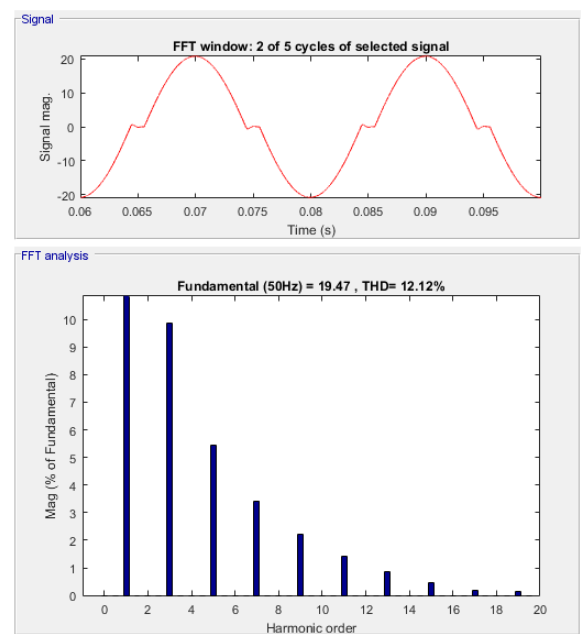

a)
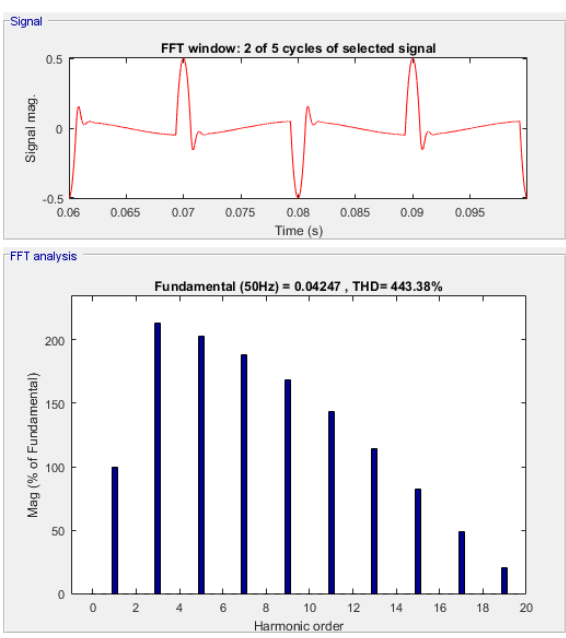

b)

Fig. 3.9. Waveform and spectrum of $Y$ connected reactive power compensator current at firing angles: a) $100^{\circ}$; b) $168^{\circ}$

It can be observed in Fig. 3.9 that current of $\mathrm{Y}$ connected reactive power compensator can be successfully controlled by variation of firing angle. $\mathrm{Y}$ connection with neutral assumes reactive power to each phase independently therefore it was chosen for further asymmetric reactive power compensator. 


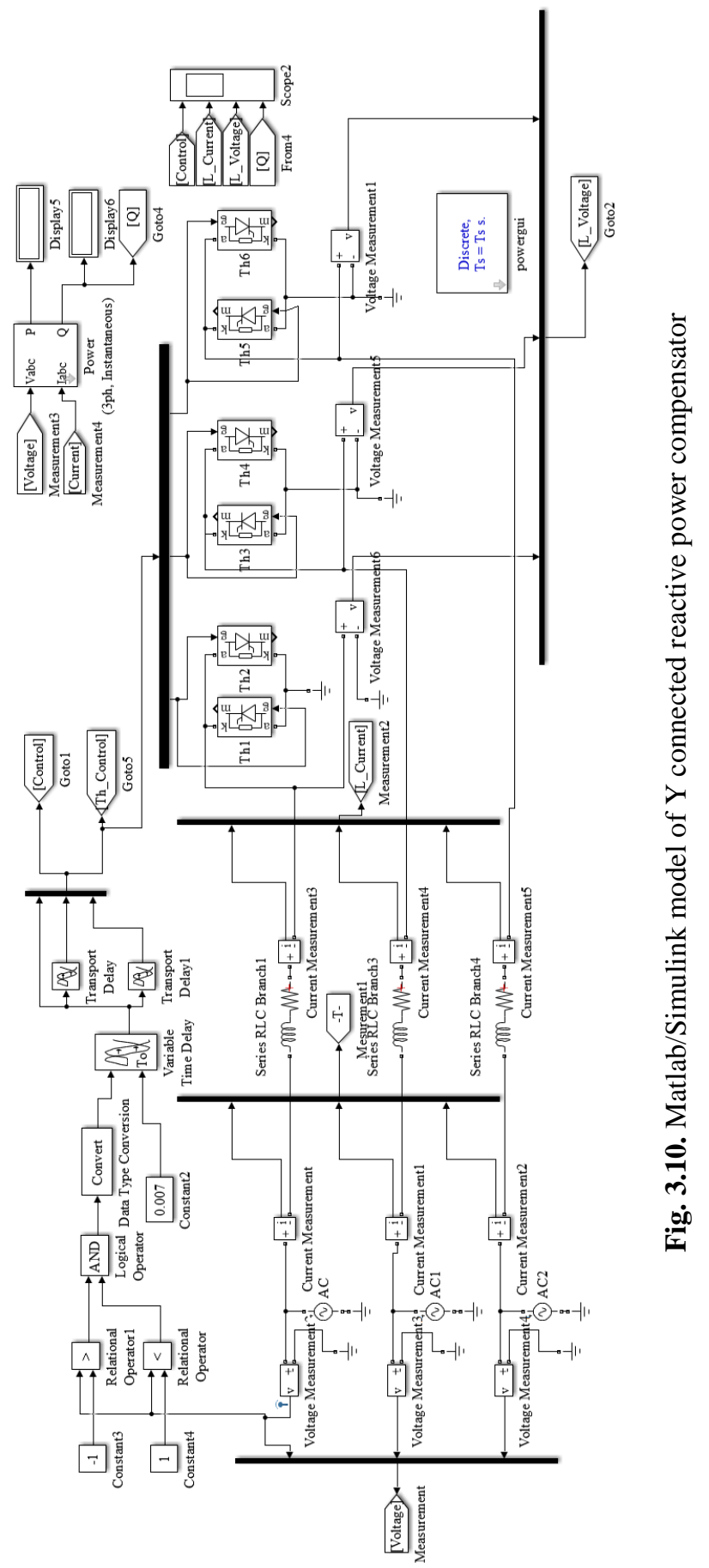


Power factor of real application utility grid load is usually $P F \geq 0.8$, as majority of consumed power is active. Waveform and spectrum of $Y$ and $\Delta$ connected reactive power compensator current for real application utility grid is presented in Fig. 3.11 .

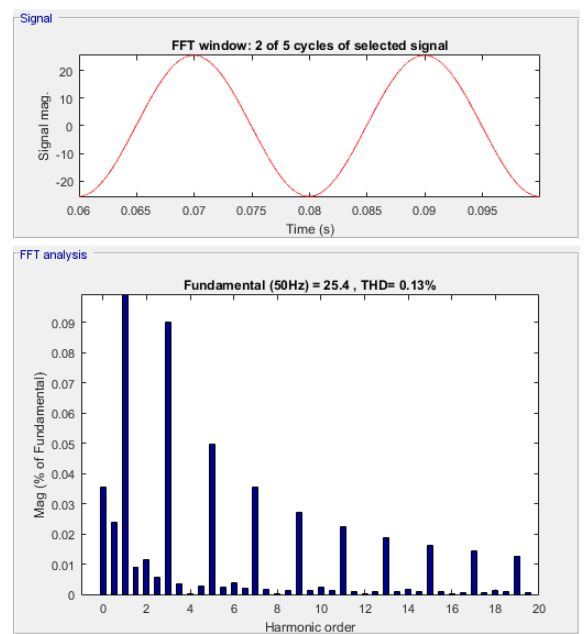

a)
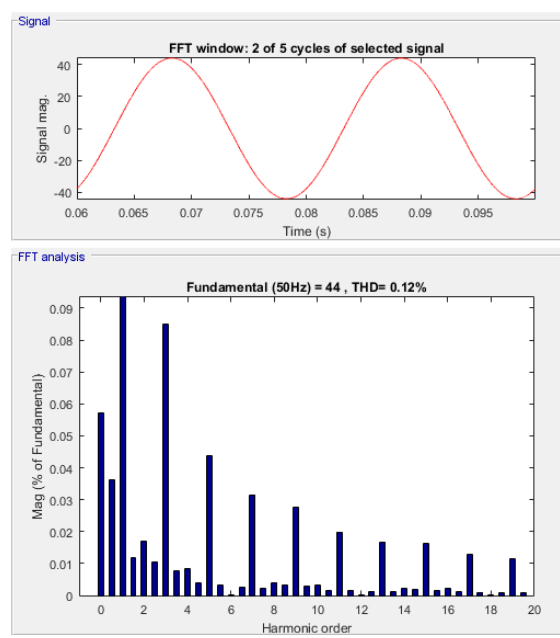

b)

Fig. 3.11. Waveforms and spectrum of reactor current: a) when Y connected is empyed;

b) when $\Delta$ connected reactor is employed

It should be stressed that THD of shunt-connected reactive power compensator depends on compensated reactive power: the more reactive power is compensated the less is THD. This is due to variation of thyristor firing angle, at $\alpha=$ $90^{\circ}$ thyristor is stays open for a full period effecting in undisturbed compensator current.

\subsection{Implementation of the Symmetric Shunt-Connected Reactive Power Compensator}

Block diagram of developed smooth reactive power compensator is presented in Fig. 3.1, which consists of conventional reactive power compensator, build from capacitor banks, electromechanical relays for capacitor bank commutation to the utility grid and developed reactor for smooth compensation capabilities.

The single cored three phase air gaped reactor was designed in order to achieve sufficient reactive power compensation, low consumption of active power 
and avoiding core saturation. The cores with air gaps are usually used for the reactors to avoid their saturation. The theory dedicated to the design of magnetic materials with the air gap, including the cores of reactors, can be found in (ArabTehrani et al., 2010; Dolan et al., 2012; Dolan \& Lehn, 2007; Finotti \& Gaio, 2014; Fouda et al., 1993; Kosai et al., 2013; Lotfi \& Faridi, 2012; Luo et al., 2009; Topaloglu, 2016; Wass et al., 2006). Three phase single core EI shaped reactor was designed for total reactive power $Q=4.8 \mathrm{kVAr}$ that corresponds to RMS of phase current $I=7 \mathrm{~A}$ for low voltage utility grid phase voltage $|U|=230 \mathrm{~V}$. The impedance of the reactor has to be $|Z|=\frac{|U|}{|I|} \approx 32 \Omega$. The inductive resistance of the coil is much higher than active, therefore, $Z \approx X_{\mathrm{L}}$ and the approximate inductance of the coil can be obtained using equation $L=\frac{X_{L}}{\omega} \approx$ $100 \mathrm{mH}$, were $\omega$ is angular frequency of grid voltage. In order to avoid core saturation, the air gaped core has to be used. To obtain the desired inductance of the reactor, the approximate design parameters of the reactor coil were chosen using the equation:

$$
L=\mu_{\mathrm{I}} \mu_{0} \frac{N^{2} \cdot S}{l},
$$

where $\mu_{0}$ is free space permeability, $\mu_{\mathrm{I}}$ is relative magnetic permeability of iron core, $\mathrm{N}$ is number of turns, $\mathrm{S}$ is winding area and $\mathrm{l}$ is length of coil.

The parameters of single cored three phase air gaped reactor are presented in Table 3.1.

Table 3.1. Parameters of a single cored three-phase air gaped reactor

\begin{tabular}{ll}
\hline Parameter & Value \\
\hline Relative magnetic permeability of iron core $\mu_{\mathrm{I}}$ & 100 \\
Number of turns of coil $N$ & 510 \\
Winding area $S, \mathrm{~cm}^{2}$ & 17.6 \\
Length of coil $l, \mathrm{~cm}$ & 10.8 \\
Wire cross-section, $\mathrm{mm}^{2}$ & 1.8 \\
Inductance of coil at core air gap length $d=0, \mathrm{mH}$ & 530 \\
Inductance of coil at $d=6 \mathrm{~mm}, \mathrm{mH}$ & 100 \\
Inductance of coil at $d=10 \mathrm{~mm}, \mathrm{mH}$ & 37 \\
Inductance of coil without core, $\mathrm{mH}$ & 5.3 \\
\hline
\end{tabular}

Structure and view of designed single core air gaped reactor are presented in Fig. 3.12. 
The reactive power consumed by the reactor is determined by the duration the reactor is connected to the grid. This duration can be controlled by variation of the thyristor firing moment in relation to the grid voltage zero value crossing moment. Usually this moment is named as thyristor firing angle $\alpha$ and is expressed in angular degrees. The waveforms of utility grid voltage, reactor current and thyristor firing pulses are given in Fig. 3.13. The obtained results show that the reactive power consumed by the reactor changes in all phases by the same law. The dispersion of the reactive power between individual phases, which is about $17 \%$, is caused by the dispersion of parameters of reactor coils. The obtained results allow us to conclude that TCR compensator based on a single cored three phase reactor is suitable for the smooth symmetric compensation of reactive power in all three phases with the appropriate error, determined by the dispersion of parameters of reactor coils.

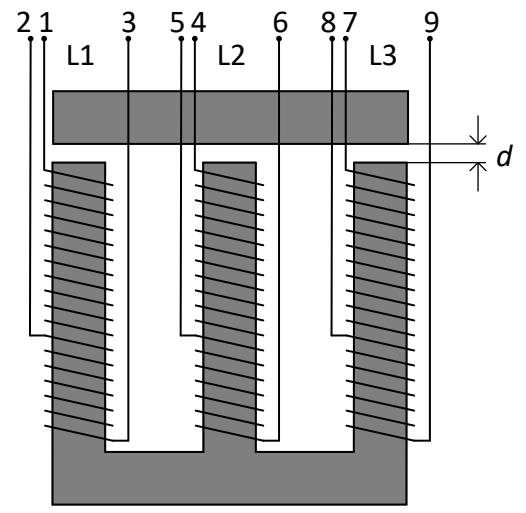

a)

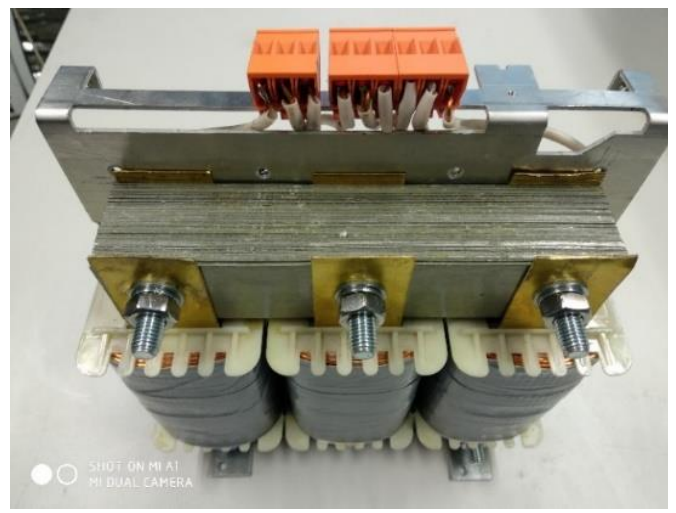

b)

Fig. 3.12. Structure and view of a single cored three-phase air gaped reactor: a) structure of reactor; b) view of reactor

The investigation results prove that TCR technique can be implemented in low voltage utility grid for symmetric compensation of reactive power with the appropriate error and that the reactive power consumed by the reactor can be controlled smoothly by control of thyristor firing angle. Additionally, it can be stated that commutation of the reactor does not introduce any high frequency disturbances of the reactor current and grid voltage (Fig. 3.13). However, for the smooth control of the reactive power consumed by the reactor, it is necessary to pass the current only for a certain part of the period. As a result, the reactor current shape is distorted, resulting in low-frequency harmonics. 


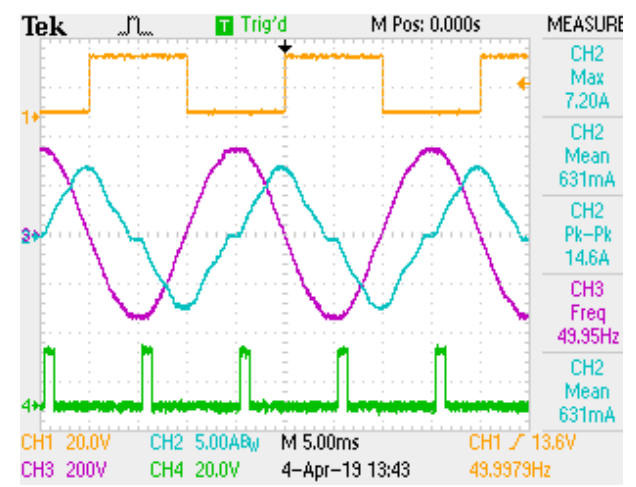

a)

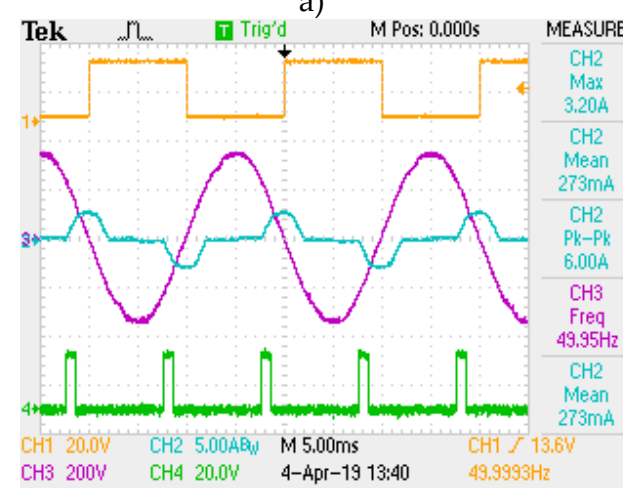

c)

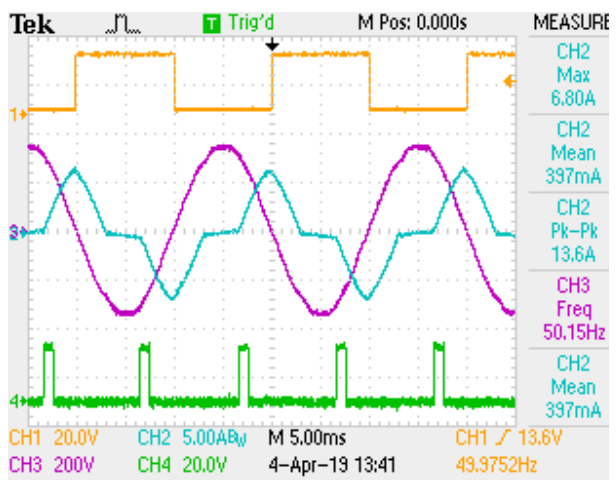

b)

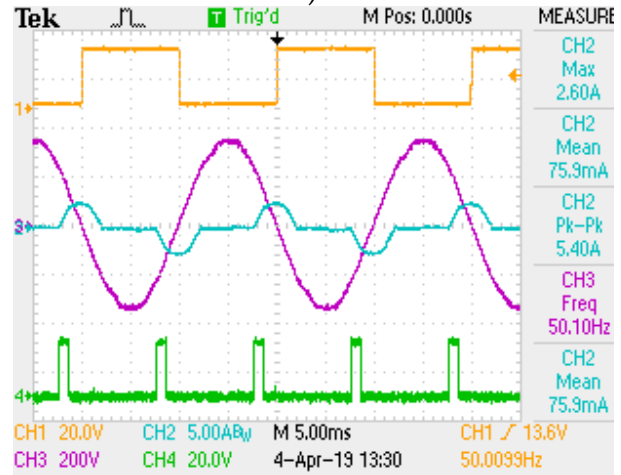

d)

Fig. 3.13. The waveforms of utility grid phase voltage (violet), reactor current (cyan) on thyristor firing angle $(\alpha)$ : a) $95^{\circ}$; b) $110^{\circ}$; c) $140^{\circ}$; d) $160^{\circ}$. Voltage zero crossing is displayed in yellow, thyristor control signal in green

Spectrum analysis was carried out employing FFT toolbox by importing oscilloscope data into Matlab/Simulink. The spectrums are obtained experimentally, therefore, harmonic 0 can appear because of measurement error or because the current curve is slightly asymmetric with respect to the time axis, i.e. some DC bias may exist. The asymmetry can be introduced by nonlinearity of our facility network, which can be caused by other devices powered from the same network. The spectrums of reactor current at various thyristor firing angles are presented in Fig. 3.14 and the total harmonic distortion (THD) - in Table 3.2. When a reactor consumes a large amount of reactive energy, which requires the current to flow through the reactor for practically the whole period, the current shape is distorted little (Fig. 3.14a). However, for the reduction of the consumed reactive energy it is necessary that the current would flow through the reactor only for part of the period, so the current shape distortion increases (Figs 3.14c, 3.14d). On the other 
hand, as the current through the reactor decreases, its effect on the overall distortion of the grid current also decreases.

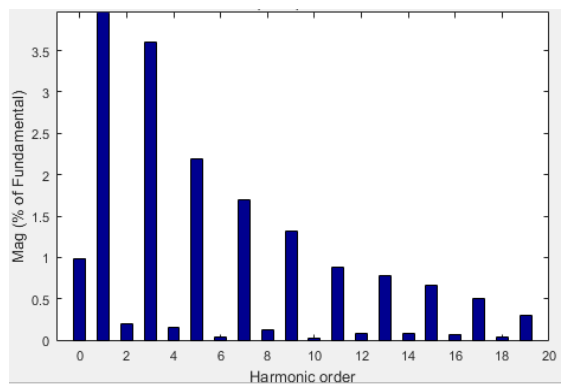

a)

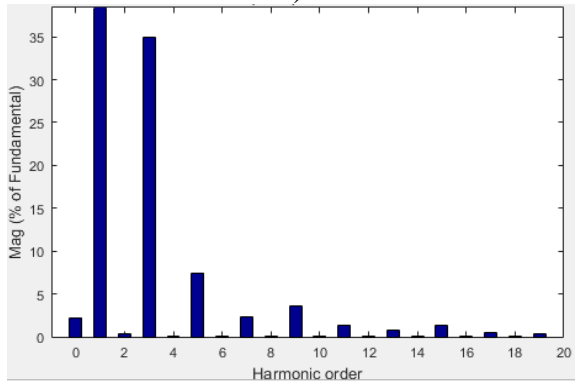

c)

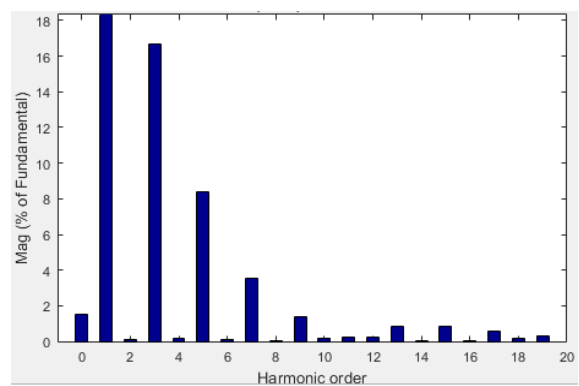

b)

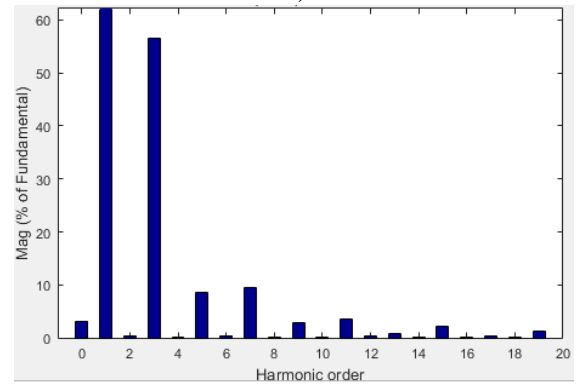

d)

Fig. 3.14. The spectrums of reactor current at various thyristor firing angles: a) $-95^{\circ}$;

b) $-110^{\circ}$; c) $-140^{\circ} ;$ d) $-160^{\circ}$. The frequency of fundamental harmonic is $50 \mathrm{~Hz}$.

Table 3.2. Total harmonic distortion of single cored three-phase air gaped reactor current

\begin{tabular}{cc}
\hline Thyristor firing angle $(\alpha)$ & Total harmonic distortion (THD), \% \\
\hline $95^{\circ}$ & 5.2 \\
$110^{\circ}$ & 19.2 \\
$140^{\circ}$ & 36.1 \\
$160^{\circ}$ & 58.3 \\
\hline
\end{tabular}

The next experiment was carried for testing of system capability of reactive power compensation. For this purpose delta connected capacitors of $C=40 \mu \mathrm{F}$ were introduced. Experimental results are presented in Fig. 3.15. 

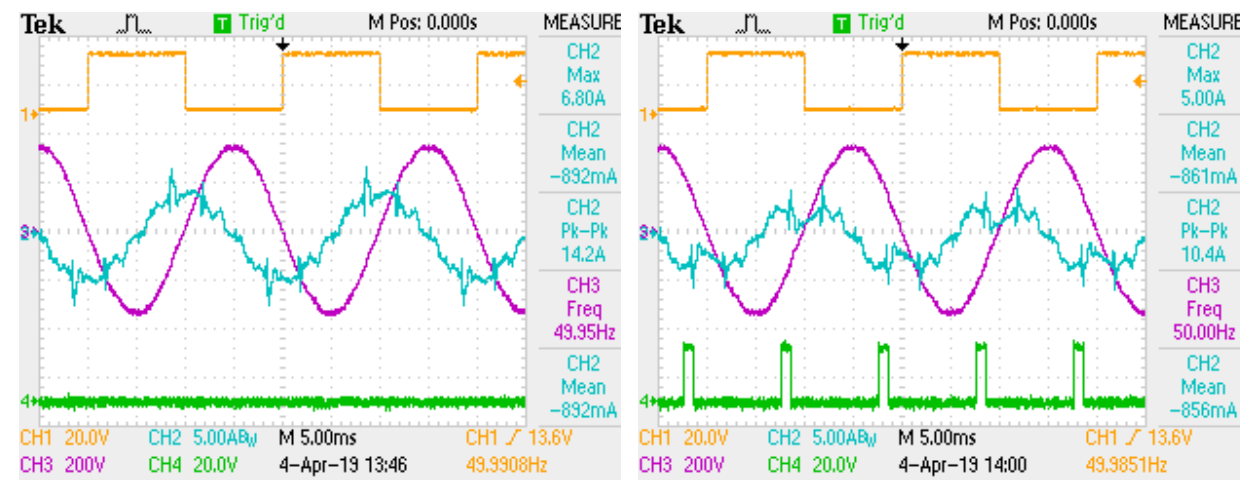

a)

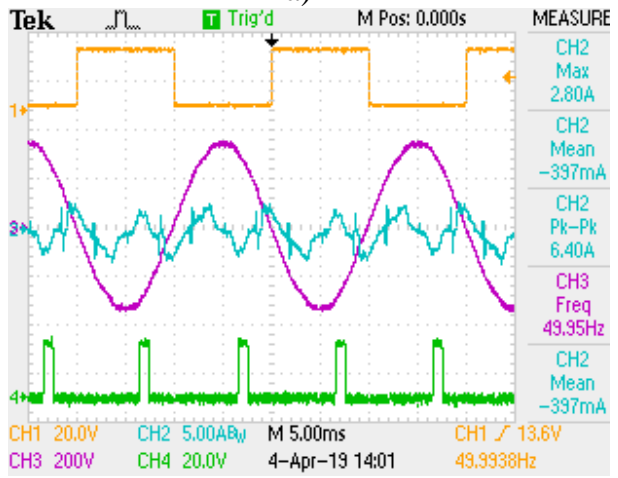

Tek MT Trig'd

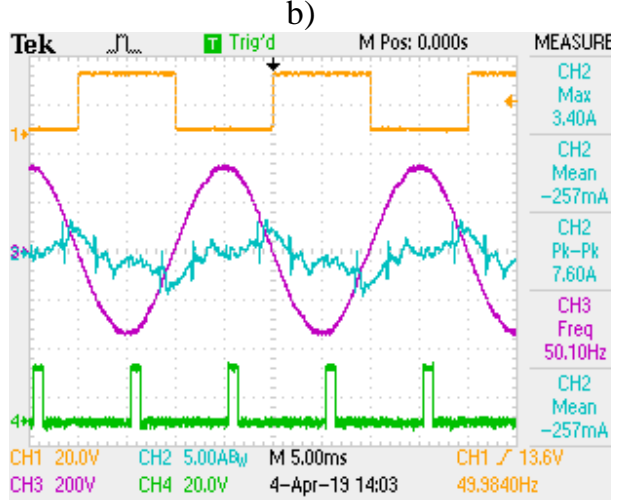

M Pos: 0.000 s

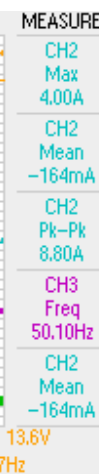

e) d)

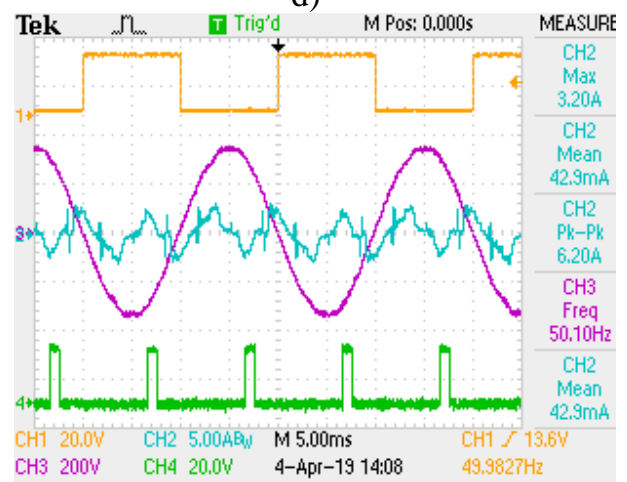

f)

Fig. 3.15. Waveforms of thyristor controlled reactor: utility grid voltage (magenta), current (cyan), at different gating angles $\alpha$ : a) $160^{\circ}(Q=-2,2 \mathrm{kVAr})$; b) $160^{\circ}$ $(Q=-1,5 \mathrm{kVAr}) ;$ c) $130^{\circ}(Q=1,1 \mathrm{kvar})$; d) $100^{\circ}(Q=1,3 \mathrm{kVAr})$;

e) $90^{\circ}(Q=1,5 \mathrm{kVAr})$; f $) 140^{\circ}(Q \approx 0)$. Zero crossing pulse signal is presented in yellow, thyristor control signal in green. 
Experimental results prove that there is possibility of reactive power compensation employing thyristor-controlled reactor. It is seen in the waveforms in Fig. 3.15 that at the gating angle of $140^{\circ}$ reactive power is compensated; therefore, load current is the lowest.

\subsection{Development of the Asymmetric Shunt-Connected Reactive Power Compensator}

\subsubsection{Test Bench of the Asymmetric Shunt-Connected Reactive Power Compensator}

The block diagram of the experimental test bench for the investigation of the developed TCR compensator for smooth asymmetric compensation of reactive power for a low-voltage utility grid is presented in Fig. 3.16. It consists of a threephase power supply $(|U|=230 \mathrm{~V}, f=50 \mathrm{~Hz})$; commutation switches SW1SW3; zero crossing circuits for each phase; thyristor switches T1-T3 for each phase; control block. The test bench was designed for the experimental investigation of the TCR compensator operation with the three-phase single-cored reactor and with separate reactors for every phase. Therefore, the single-cored three-phase Y-connected reactor (L1) with the middle point connected to neutral, three-phase

Y-connected separate phase reactors ( $\mathrm{L} 2-\mathrm{L} 4)$ with the middle point connected to neutral and switches SW2 and SW3 for commutation of reactors were included into the structure of the reactive power compensator. The power quality analyzer and oscilloscope were used for the measurement of the reactive and active power and waveforms of utility-grid voltage and current. The investigation was performed in low-voltage lines of the utility for symmetric and asymmetric phase load reactive power compensation. The $\Delta$ connection of coils as well as Y-connection with an unconnected midpoint were not used because they are not suitable for asymmetric compensation of the reactive power.

The experimental investigation results of proposed TCR compensator for smooth asymmetric compensation of reactive power in low voltage utility grid are presented in this section. Two different topologies of compensator are being investigated: topology based on a single cored three phase reactor and topology with separate reactors for the every phase. The main goal of investigations is to prove the possibility of smooth asymmetric compensation of consumed reactive power in 3 phase low voltage utility grid using TCR. The experimental test bench of the TCR compensator with single cored three phase reactor is presented in Fig. 3.17. 


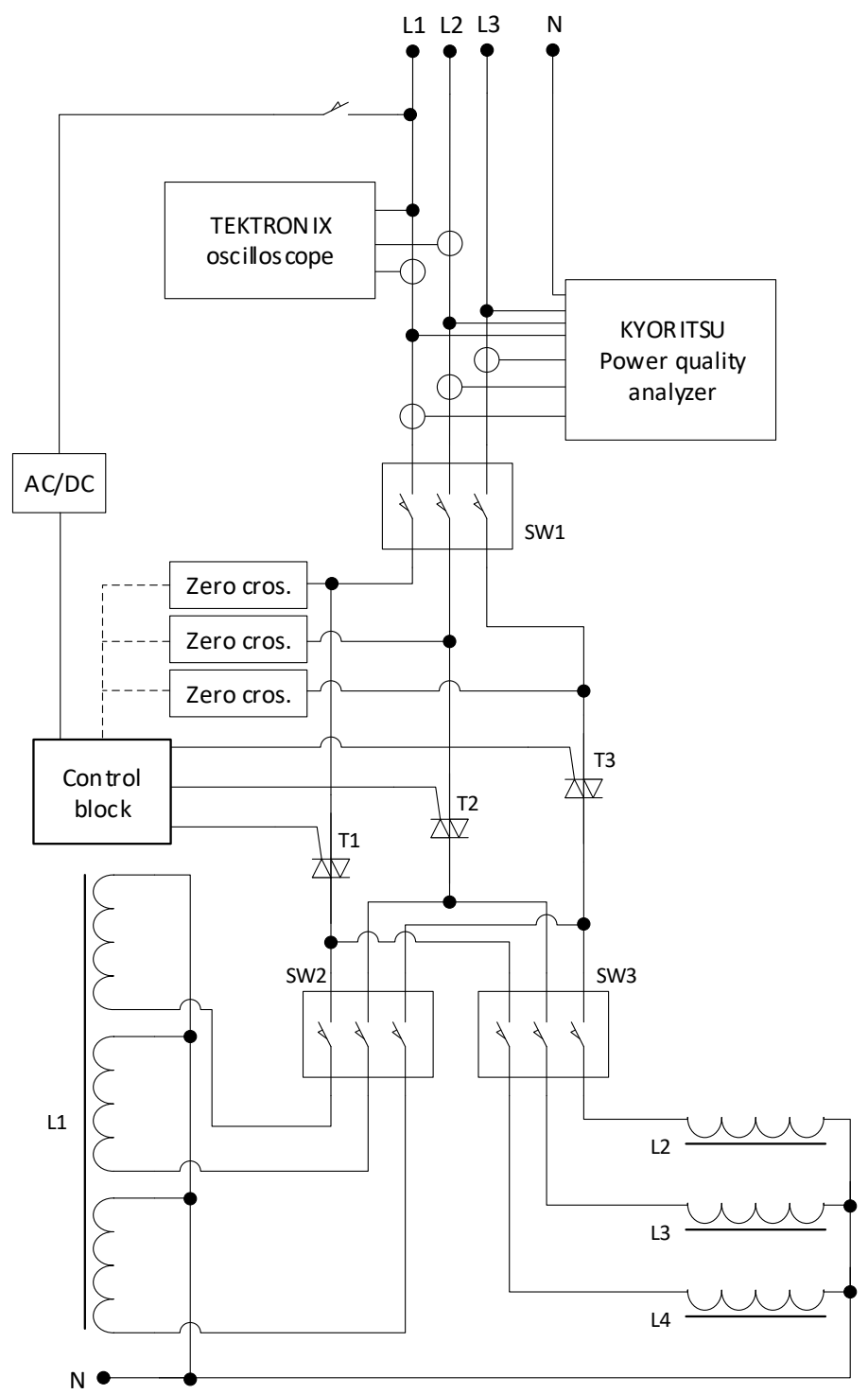

Fig. 3.16. Block diagram of asymmetric shunt-connected reactive power compensator experimental test bench 


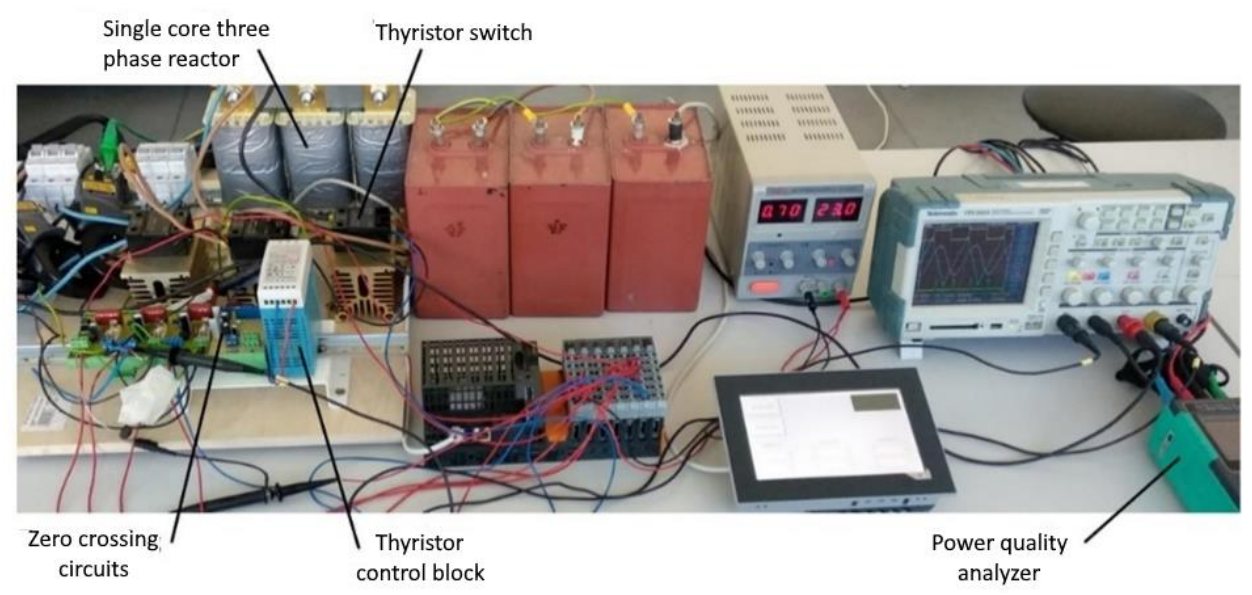

Fig. 3.17. Experimental test bench of the TCR compensator with single cored three-phase reactor

\subsubsection{Investigation of the Compensator based on a Single Cored Three-Phase Reactor}

For this investigation reactor developed in Section 3.2 was employed. The obtained reactive power dependences on the firing angle of thyristors when firing angles in all three phases are changed simultaneously (case of symmetric compensation) is presented in Fig. 3.18. Next experiment was conducted to determine whether it is possible to control the consumed reactive power in every phase independently using single cored three phase air gaped reactor. This is important because only the possibility of independent consuming of reactive power in each phase allows us to implement asymmetric compensation. The experiment was performed for the case when the firing angles of two phases were fixed: firing angle of one phase was fixed at $165^{\circ}$ (corresponds to minimal reactive power), while the firing angle of another phase - at $99^{\circ}$ (corresponds to maximal reactive power). The firing angle of the remaining phase was varied. The obtained dependences are presented in Fig. 3.19. It is seen that variation of firing angle of one phase changes not just the reactive power of controlled phase but influence the reactive power of phases with the fixed firing angles.

The nature of reactive power dependences for the phases with the fixed firing angle depends on the phase sequence. For the one sequence the reactive power is influenced only in one of the phases with a fixed angle (Figs 3.19a, 3.19b, 3.19c). For another sequence the reactive power of both phases with the fixed firing angles are affected (Figs 3.19d, 3.19e, 3.19f). 


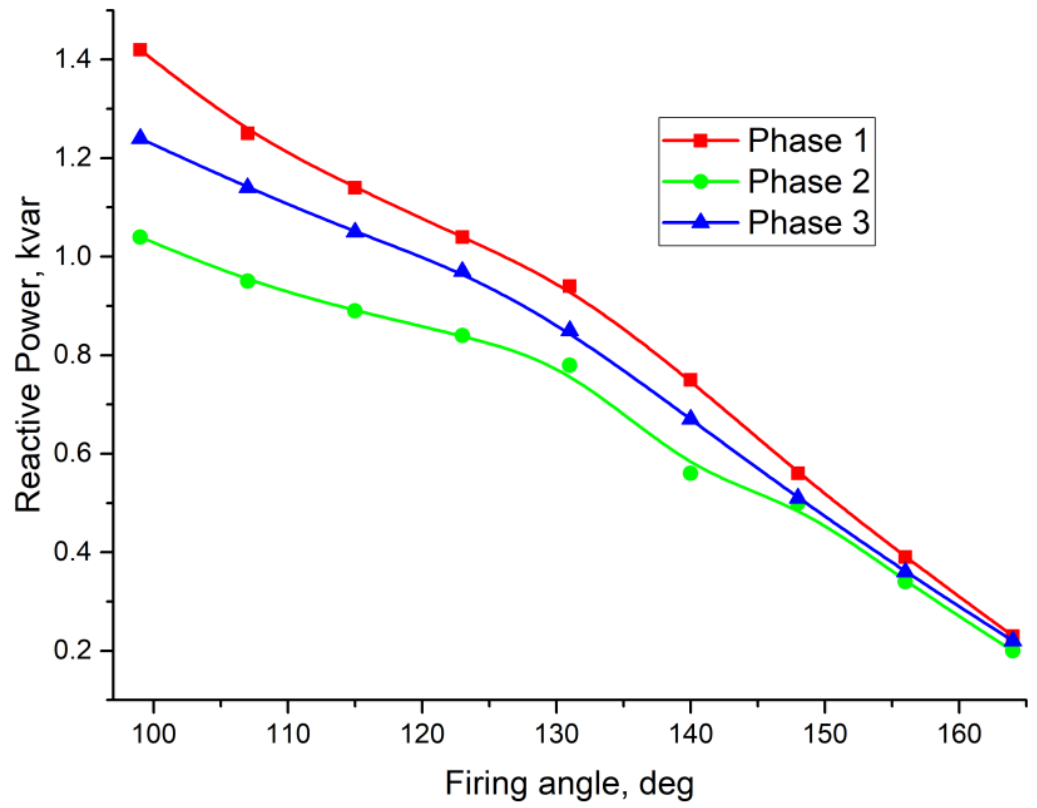

Fig. 3.18. Dependences of reactive power consumed by single cored three-phase reactor on firing angle of thyristors

During the next experiment, the firing angles of two phases were varied and the angle of the remaining phase was fixed. The investigation was performed for the case when fixed firing angle was set to $\alpha=165^{\circ}$. Dependences of reactive power consumed by the single cored three phase reactor on firing angles of two phases are presented in Fig. 3.20. It is seen that reactive power dependences of the phases with the variable firing angle strongly differ in spite that the firing angles of the thyristors are varied simultaneously. This happens due to one phase being influenced by another through the common core of the reactor.

Summarizing the obtained experimental investigation results, it can be concluded that it is impossible to control the reactive power in every phase independently using the compensator based on a single cored three phase reactor. This happens because phases influence each other truth the common core of the reactor, therefore separate reactors must be used for each phase for the asymmetric compensation of reactive power in low voltage utility grid. 


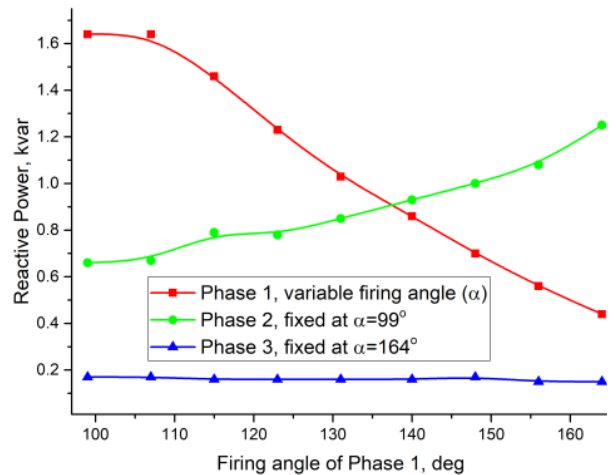

a)

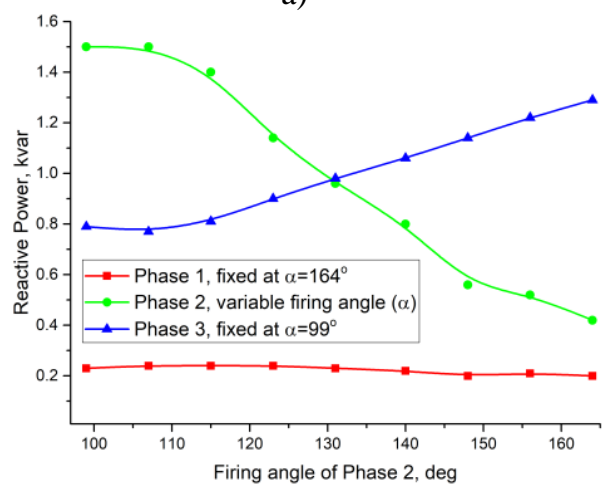

b)

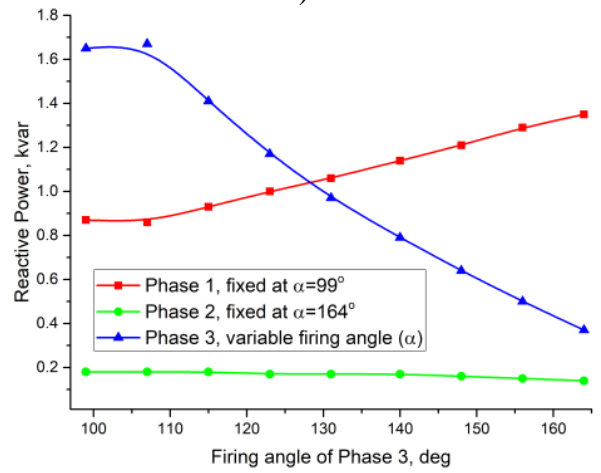

c)

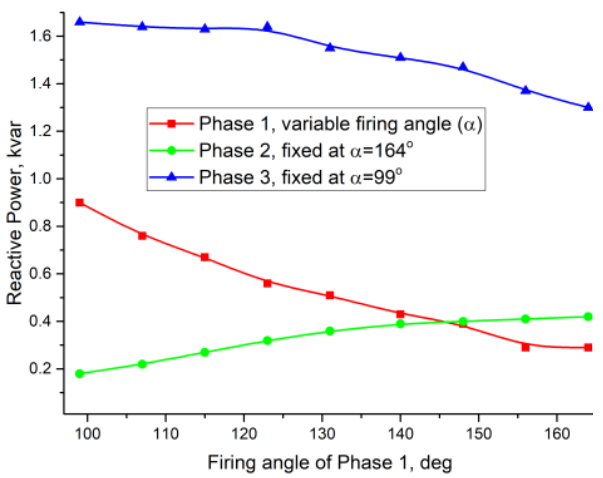

d)

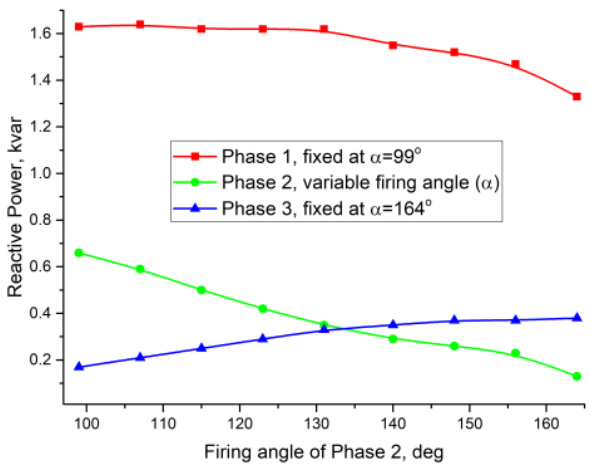

e)

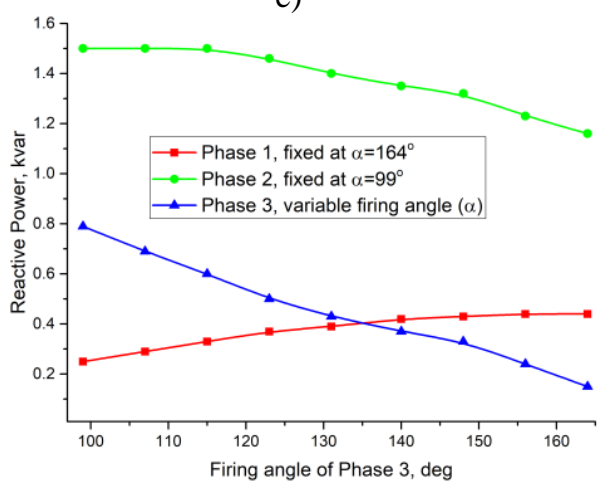

f)

Fig. 3.19. Dependences of reactive power consumed by the single cored three phase reactor on firing angle when the firing angle of one phase is variable and the angles of the remaining two phases are fixed: a) firing angle of phase 1 is variable; b) firing angle of phase 2 is variable; c) firing angle of phase 3 is variable; d) firing angle of phase 1 is variable; e) firing angle of phase 2 is variable; f) firing angle of phase 3 is variable 


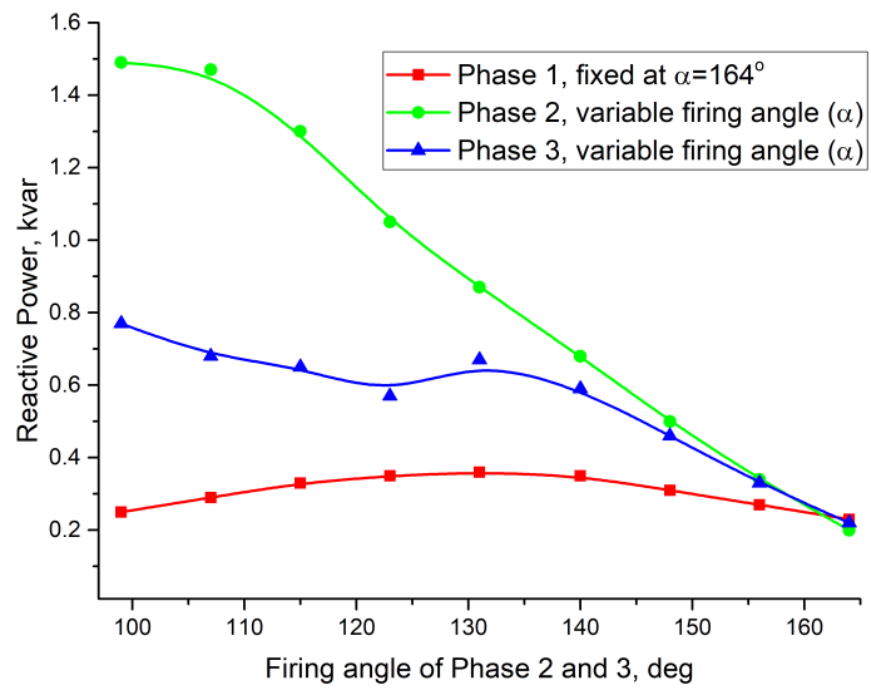

a)

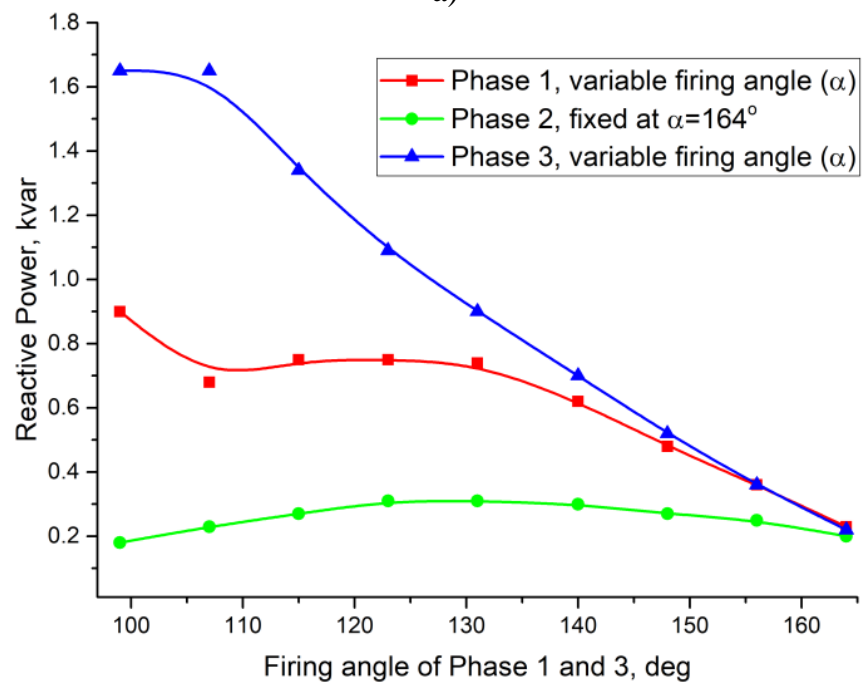

b)

Fig. 3.20. Dependences of reactive power consumed by the single cored three-phase reactor on firing angle when the firing angles of two phases are variable and the angle of the remaining phase is fixed: a) firing angles of phase 2 and phase 3 are variable;

b) firing angles of phase 1 and phase 3 are variable 


\subsubsection{Investigation of the Separate Reactors for the Every Phase based Compensator}

Structure and view of the designed air gaped reactor for single phase is presented in Fig. 3.21. Every single-phase reactor is capable to consume $4.2 \mathrm{kVAr}$ of reactive power, that corresponds to phase current RMS $I=18.5 \mathrm{~A}$ for low voltage utility grid phase voltage $|U|=230 \mathrm{~V}$. Total reactive power of all three reactors is $12.6 \mathrm{kVAr}$. The impedance of the reactor has to be $|Z|=\frac{|U|}{|I|} \approx 12.5 \Omega$, inductance $L=\frac{X_{L}}{\omega} \approx 40 \mathrm{mH}$. The required $40 \mathrm{mH}$ inductance value was achieved by adjusting the reactor air gap.

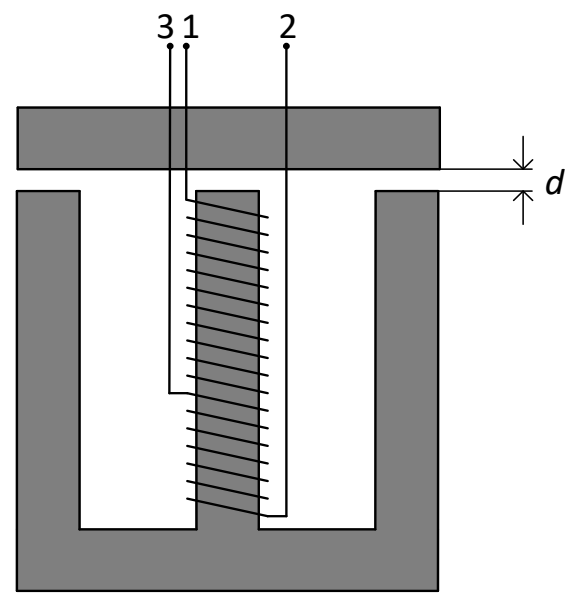

a)

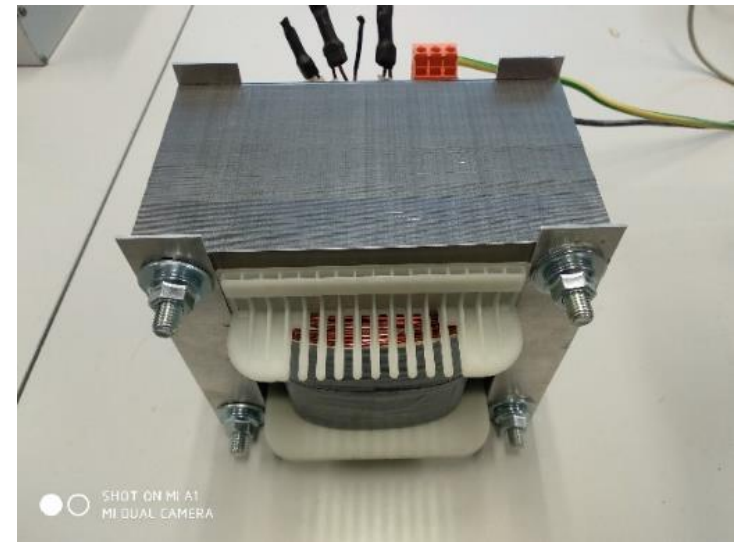

b)

Fig. 3.21. Design and view of a single phase air gaped reactor: a) design of the reactor; b) view of the reactor 
The parameters of single phase air gaped reactor are presented in Table 3.3.

Table 3.3 Parameters of single phase air gaped reactor

\begin{tabular}{ll}
\hline Parameter & Value \\
\hline Relative magnetic permeability of iron core $\mu_{\mathrm{I}}$ & 100 \\
Number of turns of coil $N$ & 160 \\
Winding area $S, \mathrm{~cm}^{2}$ & 71.5 \\
Length of coil $l, \mathrm{~cm}$ & 9.0 \\
Wire cross-section, $\mathrm{mm}^{2}$ & 3.1 \\
Inductance of coil at core air gap length $d=0, \mathrm{mH}$ & 256 \\
Inductance of coil at $d=5 \mathrm{~mm}, \mathrm{mH}$ & 40 \\
Inductance of coil at $d=10 \mathrm{~mm}, \mathrm{mH}$ & 18 \\
Inductance of coil without core, $\mathrm{mH}$ & 2.6 \\
\hline
\end{tabular}

The TCR compensator based on three single-phase air gaped reactors was investigated experimentally. Firstly, the reactive power dependences on the firing angle of thyristors when firing angles in all three phases are changed simultaneously (case of smooth symmetric compensation) were obtained (Fig. 3.22). It is seen that the reactive power consumed by the single phase reactors changes in all phases by the same law. The dispersion of the reactive power between individual phases was about $3 \%$. Next experiment was performed in the same way as in the case of TCR based on a single cored three phase air gaped reactor, i.e. the firing angles of two phases were fixed: firing angle of one phase was fixed at $165^{\circ}$, while the firing angle of another phase - at $99^{\circ}$. The firing angle of the remaining phase was varied. The obtained dependences of reactive power consumption of every phase on firing angle are presented in Fig. 3.23. It is seen that reactive power consumption of the phase with the variable firing angle has no impact on reactive power consumption of the remaining two phases with the fixed firing angles. Therefore, the conclusion can be drawn out: the employment of three single-phase reactors allows us to control the reactive power in every phase independently and the compensator with three single-phase reactors is suitable for the smooth asymmetric compensation of reactive power in low voltage utility grid.

It should be mentioned that investigation also covered the TCR compensator with $\Delta$ connection of single-phase reactor coils as well as Y connection with unconnected midpoint, however, the investigation results showed that these topologies of TCR compensator are not suitable for asymmetric load compensation. 


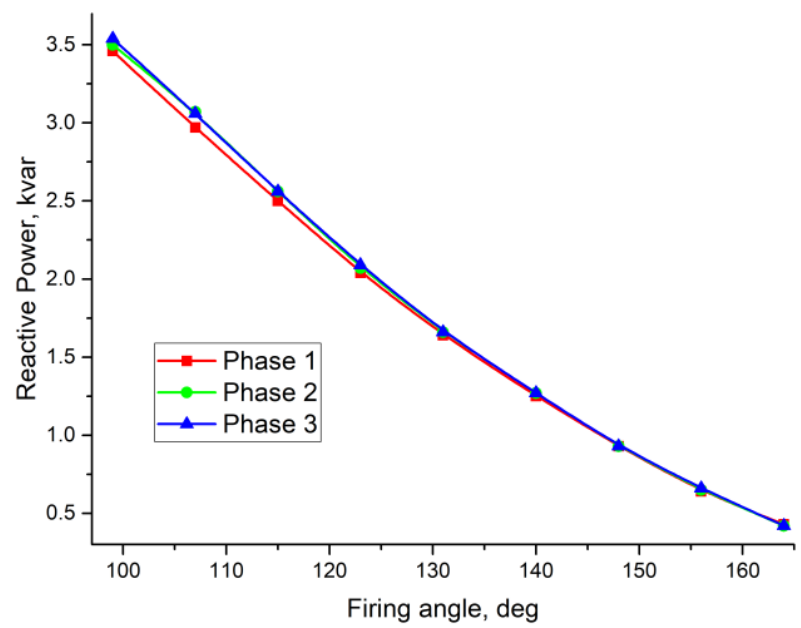

Fig. 3.22. Dependencies of reactive power consumed by the single phase air gaped reactors on firing angle of thyristors

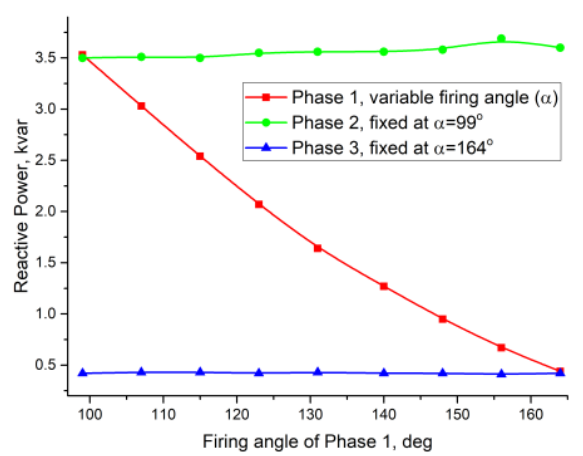

a)

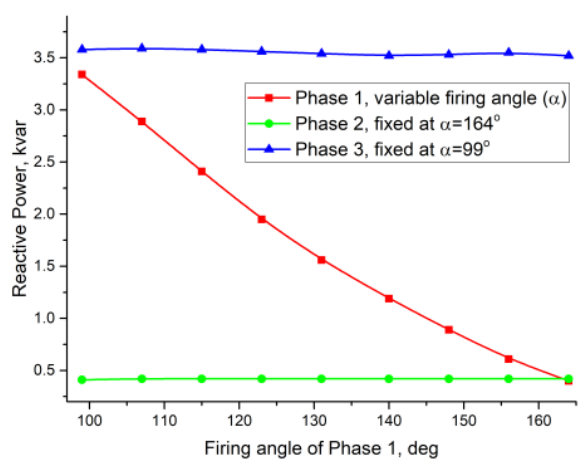

b)

Fig. 3.23. Dependences of reactive power consumed by each single phase air gaped reactor on firing angle when the firing angles of two phases are fixed and the angle of the remaining phase is variable: a) firing angles of phase 2 and phase 3 are fixed at $\alpha=99^{\circ}$ and at $\alpha=164^{\circ} ; \mathrm{b}$ ) firing angles of phase 2 and phase 3 are fixed at $\alpha=164^{\circ}$ and at $\alpha=99^{\circ}$

\subsubsection{Efficiency of Reactors}

The dependences of reactive and active power of single cored three phase and separate phase air gaped rectors were measured by applying symmetric load (Fig. 3.24). The efficiency of reactors was calculated as a ratio of reactive power 
to total power. Dependencies of reactors efficiency on firing angle are given in Fig. 3.25.

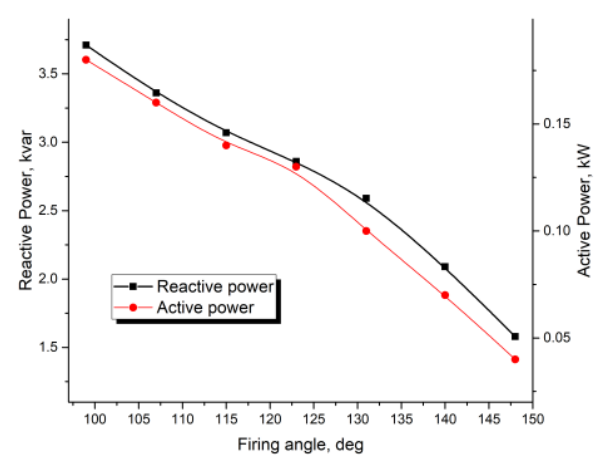

a)

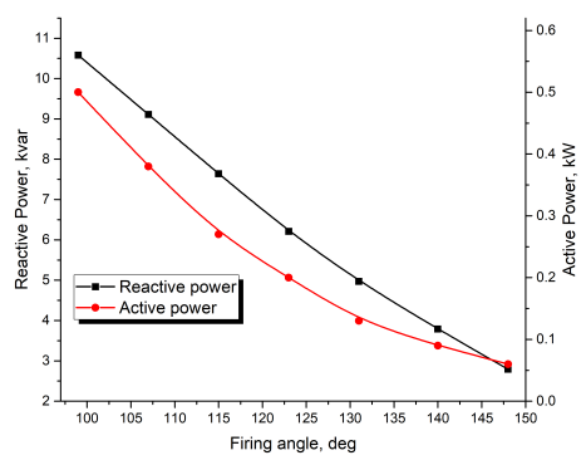

b)

Fig. 3.24. Dependences of consumed reactive and active power on firing angle:

a) consumed by the single cored three phase reactor; b) consumed by three single phase air gaped reactors

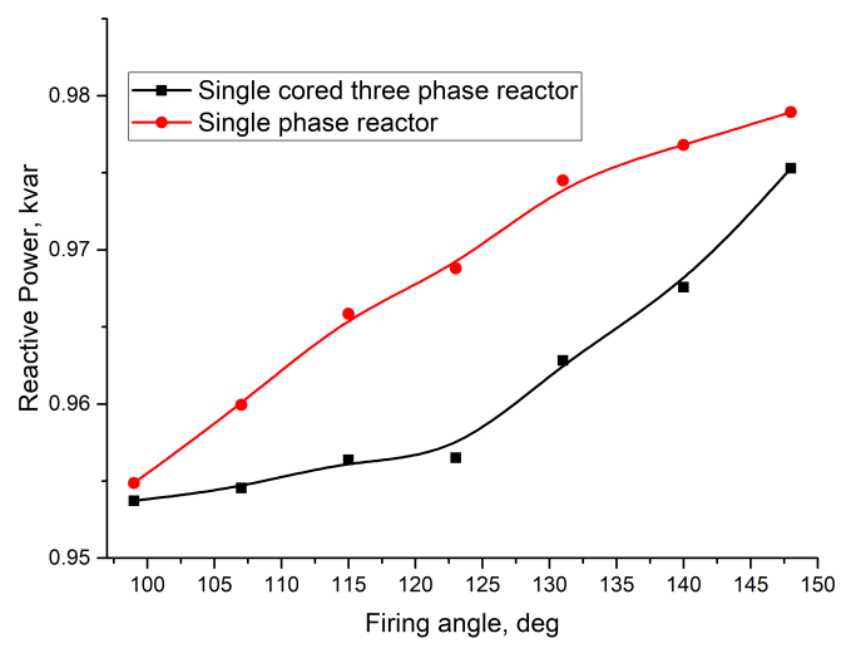

Fig. 3.25. Dependencies of reactors efficiency on firing angle

It could be observed (Fig. 3.25) that the efficiency of reactors varies from 0.955 to 0.975 when power consumed by the reactors changes from maximal to minimal value. It is seen that efficiency decreases with increasing of reactive power (with decreasing of thyristor firing angle). This appears due to the fact that 
as the reactive power increases, the reactor current increases and as a consequence, the active reactor losses increases as well.

\subsection{Conclusions of Chapter 3}

1. TCR compensators, which typically are used in the high and medium voltage utility grid, can be implemented in the low voltage utility grid employing air gapped reactors using Y connection with connected to neutral midpoint.

2. Variation of the thyristor firing angle of one phase of a single cored three phase reactor changes not just the reactive power of controlled phase but influences the reactive power of phases with the fixed firing angles, therefore a compensator with a single cored reactor is not suitable for the asymmetric compensation of the reactive power.

3. Employment of three single phase air gaped reactors allows us to control the reactive power in every phase independently, because of this, the developed TCR compensator based on three single phase reactors is suitable for the smooth and asymmetric compensation of the reactive power in the low voltage utility grid.

4. TCR compensator topologies with $\Delta$ connection of coils of single-phase reactors as well as Y connection with unconnected midpoint are not suitable for asymmetric compensation of the reactive power in the low voltage utility grid.

5. The developed single cored three-phase reactor and the single-phase reactors are characterized by $0.955-0.975$ efficiency. Therefore, developed single cored reactor and single-phase reactors for each phase are suitable for efficient reactive power compensation. 


\section{General Conclusions}

1. The cascaded inverter-based compensator realized using two in series connected inverters, one of which operates at $50 \mathrm{~Hz}$ grid frequency and another one - at $8 \mathrm{kHz}$ frequency using pulse width modulation technique, allows to develop the compensator using the combination of thyristor-based and MOSFET transistor-based inverters

2. Conventional and cascaded inverter-based reactive power compensators with the individual inverters for the every phase with neutral connection are capable to provide asymmetric compensation of reactive power in the low voltage utility grid.

3. Thyristor controlled reactor based shunt-connected reactive power compensators, which typically are used in high and medium voltage utility grid, can be implemented in the low voltage utility grid for the smooth and asymmetric compensation, employing single-phase air gapped reactors using $\mathrm{Y}$ connection with connected to neutral midpoint.

4. Variation of thyristor firing angle of one phase $90^{\circ}$ to $180^{\circ}$ of single cored three phase reactor changes not just the reactive power of controlled phase but influence the reactive power of phases with the fixed firing angles. This fact shows that it is impossible to control the reactive power in every phase independently using thyristor controlled reactor compensator based on 
a single cored three phase air gaped reactor, i.e. a compensator with such a reactor is not suitable for the asymmetric compensation of reactive power.

5. Employment of developed three single phase air gaped reactors allows us to control the reactive power up to $4 \mathrm{kVAr}$ in every phase independently with $0.955-0.975$ efficiency, i. e. developed thyristor controlled reactor compensator is suitable for the smooth and asymmetric compensation of reactive power in low voltage utility grid. 


\section{References}

Acha, E. (Ed.). (2002). Power electronic control in electrical systems. Newnes.

Acuña, P., Morán, L., Rivera, M., Dixon, J., \& Rodriguez, J. (2014). Improved Active Power Filter Performance for Renewable Power Generation Systems. IEEE Transactions on Power Electronics, 29(2), 687-694. https://doi.org/10.1109/TPEL.2013.2257854

Ali, Z., Christofides, N., Hadjidemetriou, L., \& Kyriakides, E. (2018). Photovoltaic reactive power compensation scheme: An investigation for the Cyprus distribution grid. 2018 IEEE International Energy Conference (ENERGYCON), 1-6. https://doi.org/10.1109/ENERGYCON.2018.8398746

Alkayyali, M., \& Ghaeb, J. (2020). Hybrid PSO-ANN algorithm to control TCR for voltage balancing. Transmission Distribution IET Generation, 14(5), 863-872. https://doi.org/10.1049/iet-gtd.2019.1246

Arab-Tehrani, K., Colteu, A., Rasoanarivo, I., \& Michel-Sargos, F. (2010). Design a new high intensity magnetic separator with permanent magnets for industrial applications. International Journal of Applied Electromagnetics and Mechanics, 32(4), 237-248. https://doi.org/10.3233/JAE-2010-1080

Arshad, A., \& Lehtonen, M. (2018). Instantaneous Active/Reactive Power Control Strategy for Flicker Mitigation Under High PV Penetration. 2018 IEEE PES Innovative Smart Grid Technologies Conference Europe (ISGT-Europe), 1-6. https://doi.org/10.1109/ISGTEurope.2018.8571855 
Awad, F., Mansour, A., \& Elzahab, E. (2015). Thyristor Controlled Reactor with Different Topologies Based on Fuzzy Logic Controller. International Journal of Engineering Research, 4, 498-505. https://doi.org/10.17950/ijer/v4s9/906

Babu, P. S., Mulpuri, V., SankerRam, B. V., \& Kosuru, R. (2013). Hybrid renewable sources based four leg inverter for power quality improvement. Third International Conference on Computational Intelligence and Information Technology (CIIT 2013), 612617. https://doi.org/10.1049/cp.2013.2654

Bala Nikilesh, K., \& Nageswara Rao, P. (2015). Notice of Removal: Harmonic compensation using D-STATCOM in combination with Renewable Energy Sources to enhance power quality. 2015 International Conference on Electrical, Electronics, Signals, Communication and Optimization (EESCO), 1-5. https://doi.org/10.1109/EESCO.2015.7253919

Balcells, J., \& Bogónez-Franco, P. (2013). Voltage control in a LV microgrid by means of an SVC. IECON 2013 - 39th Annual Conference of the IEEE Industrial Electronics Society, 6027-6030. https://doi.org/10.1109/IECON.2013.6700124

Barbosa, P. G., Rolim, L. G. B., Watanabe, E. H., \& Hanitsch, R. (1998). Control strategy for grid-connected DC-AC converters with load power factor correction. Transmission and Distribution IEE Proceedings - Generation, 145(5), 487-491. https://doi.org/10.1049/ip-gtd:19982174

Beck, Y., Berlovich, Y., \& Braunstein, A. (2016). A Matlab-Simulink Model of AC grid with a FC-TCR and invariant control system for reactive power compensation. 2016 International Symposium on Power Electronics, Electrical Drives, Automation and Motion (SPEEDAM), 1292-1297. https://doi.org/10.1109/SPEEDAM.2016.7525897

Beck, Y., Berlovich, Y., Muller, Z., \& Tlusty, J. (2016). A Matlab-Simulink model of network reactive power compensation based on binary switchable capacitors and thyristor-controlled reactor. 2016 IEEE International Conference on the Science of Electrical Engineering (ICSEE), 1-5. https://doi.org/10.1109/ICSEE.2016.7806150

Bielskis, E., Baskys, A., \& Valiulis, G. (2020). Controller for the Grid-Connected Microinverter Output Current Tracking. Symmetry, $12(1), \quad 112$. https://doi.org/10.3390/sym12010112

Bogónez-Franco, P., Balcells, J., Junyent, O., \& Jordà, J. (2011). SVC model for voltage control of a microgrid. 2011 IEEE International Symposium on Industrial Electronics, 1645-1649. https://doi.org/10.1109/ISIE.2011.5984407

Čerňan, M., \& Tlustý, J. (2015). Study of the susceptance control of industrial Static Var Compensator. 2015 16th International Scientific Conference on Electric Power Engineering (EPE), 538-541. https://doi.org/10.1109/EPE.2015.7161150

Chang, W.-N., \& Liao, C.-H. (2017). Design and Implementation of a STATCOM Based on a Multilevel FHB Converter with Delta-Connected Configuration for Unbalanced Load Compensation. Energies, 10(7), 921. https://doi.org/10.3390/en10070921 
Charalambous, A., Hadjidemetriou, L., Zacharia, L., Bintoudi, A. D., Tsolakis, A. C., Tzovaras, D., \& Kyriakides, E. (2019). Phase Balancing and Reactive Power Support Services for Microgrids. Applied Sciences, 9(23), 5067. https://doi.org/10.3390/app9235067

Deblecker, O., Stevanoni, C., \& Vallée, F. (2016). Cooperative control of multi-functional inverters for renewable energy integration and power quality compensation in micro-grids. 2016 International Symposium on Power Electronics, Electrical Drives, Automation and Motion (SPEEDAM), 1051-1058. https://doi.org/10.1109/SPEEDAM.2016.7525900

Dineshkumar, S., \& Senthilnathan, N. (2014). Three Phase Shunt Active Filter Interfacing Renewable Energy Source with Power Grid. 2014 Fourth International Conference on Communication Systems and Network Technologies, 1026-1031. https://doi.org/10.1109/CSNT.2014.209

Dixon, J., Moran, L., Rodriguez, J., \& Domke, R. (2005). Reactive Power Compensation Technologies: State-of-the-Art Review. Proceedings of the IEEE, 93(12), 2144-2164. https://doi.org/10.1109/JPROC.2005.859937

Dolan, D. S. L., \& Lehn, P. W. (2007). Analysis of a Virtual Air Gap Variable Reactor. 2007 IEEE Power Electronics Specialists Conference, 1182-1187. https://doi.org/10.1109/PESC.2007.4342160

Dolan, D. S. L., Lehn, P. W., \& Taufik, T. (2012). Harmonics and Dynamic Response of a Virtual Air Gap Variable Reactor. 2012 Ninth International Conference on Information Technology - New Generations, 225-231. https://doi.org/10.1109/ITNG.2012.39

Dong, T., Li, L., \& Ma, Z. (2012). A combined system of APF and SVC for power quality improvement in microgrid. 2012 Power Engineering and Automation Conference, 1-4. https://doi.org/10.1109/PEAM.2012.6612554

Farkoush, S. G., Kim, C.-H., \& Rhee, S.-B. (2016). THD Reduction of Distribution System Based on ASRFC and HVC Method for SVC under EV Charger Condition for Power Factor Improvement. Symmetry, 8(12), 156. https://doi.org/10.3390/sym8120156

Finotti, C., \& Gaio, E. (2014). Continuous model in dq frame of Thyristor Controlled Reactors for stability analysis of high power electrical systems. International Journal of Electrical Power \& Energy Systems, 63, 836-845. https://doi.org/10.1016/j.ijepes.2014.06.045

Fouda, S. S., Salama, M. M. A., \& Chikhani, A. Y. (1993). Characteristic performance of thyristor controlled reactor used in reactive power control. Proceedings of Canadian Conference on Electrical and Computer Engineering, 445-448 vol.1. https://doi.org/10.1109/CCECE.1993.332344

Fuchs, E., \& Masoum, M. A. S. (2011). Power Quality in Power Systems and Electrical Machines. Academic Press.

Gayatri, M. T. L., Parimi, A. M., \& Kumar, A. V. P. (2018). A Review of Reactive Power Compensation Techniques in Microgrids. Renewable and Sustainable Energy Reviews, 81(1), 1030-1036. https://doi.org/doi:10.1016/j.rser.2017.08.006 
Gururaj M V, Vinatha U., \& Jayasankar V N. (2015). Interconnection of wind-solar hybrid Renewable Energy source to the 3 phase-3 wire distribution system along with power quality improvements at the grid side. 2015 International Conference on Power and Advanced Control Engineering (ICPACE), 168-172. https://doi.org/10.1109/ICPACE.2015.7274937

Haykin, S., \& Van Veen, B. (2003). Signals and Systems. John Wiley \& Sons.

Holms, D. G., \& Lipo, T. A. (2003). Pulse Width Modulation for Power Converters Principles and Practice. Wiley-IEEE Press.

Hong $\mathrm{Hu}$, Wenmei Wu, Shaohua Xiao, Min Tan, \& Chuanjia Han. (2015, rugsèjo). Summary on Reactive Power Compensation Technology and Application. 2nd International Conference on Intelligent Computing and Cognitive Informatics (ICICCI 2015). https://doi.org/10.2991/icicci-15.2015.48

Igbinovia, F., Fandi, G., Svec, J., Muller, Z., \& Tlusty, J. (2015). Comparative review of reactive power compensation technologies. Proceedings of the 2015 16th International Scientific Conference on Electric Power Engineering, EPE 2015, 2-7. https://doi.org/10.1109/EPE.2015.7161066

Ilango, K., Manitha, P. V., \& Nair, M. G. (2012). An enhanced controller for shunt active filter interfacing renewable energy source and grid. 2012 IEEE Third International Conference on Sustainable Energy Technologies (ICSET), 305-310. https://doi.org/10.1109/ICSET.2012.6357416

Ilisiu, D., \& Dinu, E.-D. (2019). Modern Reactive Power Compensation for Smart Electrical Grids. 2019 22nd International Conference on Control Systems and Computer Science (CSCS), 353-357. https://doi.org/10.1109/CSCS.2019.00063

Jabir, H., Mekhilef, S., Nakaoka, M., \& Nishida, K. (2013). Development of a transformer-based multilevel inverter topology for stand-alone photovoltaic system. 201315 th European Conference on Power Electronics and Applications (EPE), 1-10. https://doi.org/10.1109/EPE.2013.6634333

Khonde, R. S., \& Palandurkar, M. V. (2014). Simulation Model of Thyristor Controlled Reactor. International Journal of Engineering Research \& Technology, 3(4). https://www.ijert.org/research/simulation-model-of-thyristor-controlled-reactor-

IJERTV3IS041805.pdf, https://www.ijert.org/simulation-model-of-thyristor-controlledreactor

Kosai, H., Turgut, Z., \& Scofield, J. (2013). Experimental Investigation of DC-Bias Related Core Losses in a Boost Inductor. IEEE Transactions on Magnetics, 49(7), 41684171. https://doi.org/10.1109/TMAG.2013.2242863

Köse, A., \& Irmak, E. (2016). Modeling and simulation of a static VAR compensator based on FC-TCR. 2016 IEEE International Conference on Renewable Energy Research and Applications (ICRERA), 924-927. https://doi.org/10.1109/ICRERA.2016.7884470 
Li, B., Tian, X., \& Zeng, H. (2011). A grid-connection control scheme of PV system with fluctuant reactive load. 2011 4th International Conference on Electric Utility Deregulation and Restructuring and Power Technologies (DRPT), 786-790. https://doi.org/10.1109/DRPT.2011.5993999

Liberado, E. V., Souza, W. A., Pomilio, J. A., Paredes, H. K. M., \& Marafão, F. P. (2013). Design of static VAr compensator using a general reactive energy definition. International School on Nonsinusoidal Currents and Compensation 2013 (ISNCC 2013), 1-6. https://doi.org/10.1109/ISNCC.2013.6604455

Liu, Y., Yang, S., Wang, X., Gunasekaran, D., Karki, U., \& Peng, F. Z. (2016). Application of Transformer-Less UPFC for Interconnecting Two Synchronous AC Grids With Large Phase Difference. IEEE Transactions on Power Electronics, 31(9), 6092-6103. https://doi.org/10.1109/TPEL.2015.2500033

Lotfi, A., \& Faridi, M. (2012). Design Optimization of Gapped-Core Shunt Reactors. IEEE Transactions on Magnetics, 48(4), 1673-1676. https://doi.org/10.1109/TMAG.2011.2173180

Luo, A., Shuai, Z., Zhu, W., \& Shen, Z. J. (2009). Combined System for Harmonic Suppression and Reactive Power Compensation. IEEE Transactions on Industrial Electronics, 56(2), 418-428. https://doi.org/10.1109/TIE.2008.2008357

Macken, K. J. P., Vanthournout, K., Van den Keybus, J., Deconinck, G., \& Belmans, R. J. M. (2004). Distributed control of renewable generation units with integrated active filter. IEEE Transactions on Power Electronics, 19(5), 1353-1360. https://doi.org/10.1109/TPEL.2004.833450

Mahapatra, S., Goyal, A., \& Kapil, N. (2014). Thyristor Controlled Reactor for Power Factor Improvement.

Mathur, R. M., \& Varma, R. K. (2002). Thyristor-Based FACTS Controllers for Electrical Transmission Systems. IEEE. https://doi.org/10.1109/9780470546680

Merai, M., Naouar, M. W., \& Slama-Belkhodja, I. (2015). Power capability of MultiFunction Grid connected Converters. IREC2015 The Sixth International Renewable Energy Congress, 1-6. https://doi.org/10.1109/IREC.2015.7110878

Mukhopadhyay, S., Maiti, D., Banerji, A., Biswas, S. K., \& Deb, N. K. (2017). A New Harmonic Reduced Three-Phase Thyristor-Controlled Reactor for Static VAr Compensators. IEEE Transactions on Industrial Electronics, 64(9), 6898-6907. https://doi.org/10.1109/TIE.2017.2694409

Mukhopadhyay, S., Maiti, D., Biswas, S. K., Banerji, A., \& Deb, N. K. (2018). A WideRange TCR With Low-Current THD by Optimized Combination of Coupled Reactors and Thyristor Switching and Control. IEEE Transactions on Industrial Electronics, 65(5), 3657-3665. https://doi.org/10.1109/TIE.2017.2764862

Neves, P., Gonçalves, D., Pinto, J. G., Alves, R., \& Afonso, J. L. (2009). Single-phase Shunt Active Filter interfacing renewable energy sources with the power grid. 2009 35th Annual Conference of IEEE Industrial Electronics, 3264-3269. https://doi.org/10.1109/IECON.2009.5415208 
P, K., \& Mahapatra, K. (2011). Cascaded multilevel inverter based active filter for power line conditioners using instantaneous real-power theory. India International Conference on Power Electronics $2010 \quad$ (IICPE2010), 1-6. https://doi.org/10.1109/IICPE.2011.5768167

Padiyar, R. K. (2007). Facts Controllers in Power Transmission and Distribution. New Age International (P) Ltd.

Pană, A., Băloi, A., \& Molnar-Matei, F. (2018a). From the Balancing Reactive Compensator to the Balancing Capacitive Compensator. Energies, 11(8), 1979. https://doi.org/10.3390/en11081979

Pană, A., Băloi, A., \& Molnar-Matei, F. (2018b). Iterative Method for Determining the Values of the Susceptances of a Balancing Capacitive Compensator. Energies, 11(10), 2742. https://doi.org/10.3390/en11102742

Panfilov, D. I., \& ElGebaly, A. E. (2016). Modified thyristor controlled reactor for static VAR compensators. 2016 IEEE International Conference on Power and Energy (PECon), 712-717. https://doi.org/10.1109/PECON.2016.7951652

Panfilov, D. I., ElGebaly, A. E., \& Astashev, M. G. (2017a). Design and evaluation of control system for static VAR compensators with thyristors switched reactors. 2017 IEEE 58th International Scientific Conference on Power and Electrical Engineering of Riga Technical University (RTUCON), 1-6. https://doi.org/10.1109/RTUCON.2017.8124782

Panfilov, D. I., ElGebaly, A. E., \& Astashev, M. G. (2017b). Topologies of thyristor controlled reactor with reduced current harmonic content for static VAR compensators. 2017 IEEE International Conference on Environment and Electrical Engineering and 2017 IEEE Industrial and Commercial Power Systems Europe (EEEIC / I CPS Europe), 1-6. https://doi.org/10.1109/EEEIC.2017.7977422

Panfilov, Dmitry I., Rozhkov, A. N., Astashev, M. G., \& Zhuravlev, I. I. (2019). Modern Approaches to Controlled Static VAR Compensators design. 2019 IEEE International Conference on Environment and Electrical Engineering and 2019 IEEE Industrial and Commercial Power Systems Europe (EEEIC / I CPS Europe), 1-5. https://doi.org/10.1109/EEEIC.2019.8783619

Patel, H. K., \& Dubey, G. K. (1983). Harmonic reduction in the static VAR compensator by sequence control of transformer taps. Transmission and Distribution IEE Proceedings C - Generation, 130(6), 300-305. https://doi.org/10.1049/ip-c.1983.0055

Pikutis, M., Vasarevicius, D., \& Martavicius, R. (2014). Maximum Power Point Tracking in Solar Power Plants under Partially Shaded Condition. Elektronika Ir Elektrotechnika, 20(4), 49-52. https://doi.org/10.5755/j01.eee.20.4.6677

Pouresmaeil, E., Shaker, H. R., Mehrasa, M., Shokridehaki, M. A., Rodrigues, E. M. G., \& Catalão, J. P. S. (2015). Integration of renewable energy for the harmonic current and reactive power compensation. 2015 IEEE 5th International Conference on Power Engineering, Energy and Electrical Drives (POWERENG), 31-36. https://doi.org/10.1109/PowerEng.2015.7266292 
PQC-STATCON. (2011). ABB Limited. https://library.e.abb.com/public/2b588b8dd20ce996c1257a37003639e4/PQC-STATCON_Flyer.pdf

Rahmani, S., Hamadi, A., Al-Haddad, K., \& Dessaint, L. A. (2014). A Combination of Shunt Hybrid Power Filter and Thyristor-Controlled Reactor for Power Quality. IEEE Transactions on Industrial Electronics, 61(5), 2152-2164. https://doi.org/10.1109/TIE.2013.2272271

Rao, S. N., Kumar, D. V. A., \& Babu, Ch. S. (2013). New multilevel inverter topology with reduced number of switches using advanced modulation strategies. 2013 International Conference on Power, Energy and Control (ICPEC), 693-699. https://doi.org/10.1109/ICPEC.2013.6527745

Rozanov, Y., Ryvkin, S., Chaplygin, E., \& Voronin, P. (2016). Power Electronics Basics: Operating Principles, Design, Formulas, and Applications. CRC Press Taylor and Francis Group.

Santacana, E., Rackliffe, G., Tang, L., \& Feng, X. (2010). Getting Smart. IEEE Power and Energy Magazine, 8(2), 41-48. https://doi.org/10.1109/MPE.2009.935557

Sethi, H., Chopra, D., \& Meikandasivam, S. (2014). Power Factor Correction ussing SVC Technique. VIT University.

Singh, M., Khadkikar, V., Chandra, A., \& Varma, R. K. (2011). Grid Interconnection of Renewable Energy Sources at the Distribution Level With Power-Quality Improvement Features. IEEE Transactions on Power Delivery, 26(1), 307-315. https://doi.org/10.1109/TPWRD.2010.2081384

Stanelyte, D., \& Radziukynas, V. (2020). Review of Voltage and Reactive Power Control Algorithms in Electrical Distribution Networks. Energies, 13(1), 58. https://doi.org/10.3390/en13010058

Sullivan, D. J. (n.d.). Improvements in Voltage Control and Dynamic Performance of Power Transmission Systems using Static VAR Compensators (SVC). 55.

Tehrani, K.-A., Capitaine, T., Barrandon, L., Hamzaoui, M., Rafiei, S. M. R., \& Lebrun, A. (2011). Current control design with a fractional-order PID for a three-level inverter. Proceedings of the 2011 14th European Conference on Power Electronics and Applications, 1-7.

Tokiwa, A., Yamada, H., Tanaka, T., Watanabe, M., Shirai, M., \& Teranishi, Y. (2017). New Hybrid Static VAR Compensator with Series Active Filter. Energies, 10(10), 1617. https://doi.org/10.3390/en10101617

Tong XiangQian, Xi Keqing, Shen Ming, \& Ma Xianhong. (2005). Reactive power and unbalance compensation with DSTATCOM. 2005 International Conference on Electrical Machines and Systems, 2, 1181-1184. https://doi.org/10.1109/ICEMS.2005.202733

Topaloglu, I. (2016). Air Gap Optimization of Iron Core Shunt Reactors with Discretely Disturbed Air Gaps for UHV Systems. International Conference on Engineering and Natural Science (ICENS 2016), 1-6. https://doi.org/10.13140/RG.2.1.1386.2007 
Trentini, F., Tasca, M., Tomasin, S., \& Erseghe, T. (2012). Reactive power compensation in smart micro grids: A prime-based testbed. 2012 IEEE International Energy Conference and Exhibition (ENERGYCON), 909-914. https://doi.org/10.1109/EnergyCon.2012.6348280

Vechiu, I., Etxeberria, A., \& Tabart, Q. (2015). Power quality improvement using an advanced control of a four-leg multilevel converter. 2015 IEEE 16th Workshop on Control and Modeling for Power Electronics (COMPEL), 1-6. https://doi.org/10.1109/COMPEL.2015.7236486

Wass, T., Hörnfeldt, S., \& Valdemarsson, S. (2006). The design and construction of a controllable reactor with a HTS control winding. Journal of Physics: Conference Series, 43, 873. https://doi.org/10.1088/1742-6596/43/1/213

Xu, Y., Tolbert, L. M., Kueck, J. D., \& Rizy, D. T. (2010). Voltage and current unbalance compensation using a static var compensator. IET Power Electronics, 3(6), 977-988. https://doi.org/10.1049/iet-pel.2008.0094

Yan, J. (Ed.). (2015). Handbook of Clean Energy Systems, 6 Volume Set (1 edition). Wiley.

Yong Xue, Jiamei Deng, \& Shuangbao Ma. (2009). Power flow control of a distributed generation unit in micro-grid. 2009 IEEE 6th International Power Electronics and Motion Control Conference, 2122-2125. https://doi.org/10.1109/IPEMC.2009.5157750 


\section{List of Scientific Publications by the Author on the Topic of the Dissertation}

\section{Papers in the Reviewed Scientific Journals}

Šapurov, M., Bleizgys, V., Baskys, A., Dervinis, A., Bielskis, E., Paulikas, S., Paulauskas, N., \& Macaitis, V. (2020). Asymmetric Compensation of Reactive Power Using Thyristor-Controlled Reactors. Symmetry, 12(6), 880. https://doi.org/10.3390/sym12060880 Šapurov, M., Bielskis, E., Bleizgys, V., \& Dervinis, A. (2020). Stepless compensator of reactive power. Mokslas - Lietuvos Ateitis / Science - Future of Lithuania, 12. https://doi.org/10.3846/mla.2020.11441

Šapurov, M., Dervinis, A., Bielskis, E., \& Bleizgys, V. (2020). Development of high power microsecond pulse generator. Mokslas - Lietuvos Ateitis / Science - Future of Lithuania, 12. https://doi.org/10.3846/mla.2020.11443

\section{Papers in Other Editions}

Sapurov, M., Baskys, A., Bielskis, E., Bleizgys, V., \& Rabinovici, R. (2017). Single phase cascaded inverter for renewable energy supplies, in Proc. of Electronics 2017, Palanga: 1-5. https://doi.org/10.1109/ELECTRONICS.2017.7995224 



\section{Summary in Lithuanian}

\section{Ivadas}

\section{Problemos formulavimas}

Elektros tinkluose tiekiama ir vartojama dviejų tipų elektros energiją: aktyvioji ir reaktyvioji. Naudingą darbą atlieka tik vartojama aktyvioji energija. Reaktyvioji energija pulsuoja tarp elektros energijos šaltinio ir reaktyviosios apkrovos ir sukelia nereikalingus energijos nuostolius. Reaktyvioji galia yra sąlygojama tinklo apkrovų, kurios naudoja arba generuoja ne tik aktyviają, bet ir reaktyviają galią. Reaktyviają galią gali sukurti ir harmoniniai tinklo srovès iškraipymai, kuriuos sukelia netiesinès apkrovos. Reaktyvioji galia padidina srovę elektros tinklo perdavimo linijose, kabeliuose, transformatoriuose ir jungikliuose, t. y. reaktyvioji galia sukelia papildomą nenaudingą apkrovą. Taigi, jei tiekiama arba vartojama reaktyvioji energija, elektros tinklas turi būti suprojektuotas didesnei galiai, atsižvelgiant ne tik ị aktyviąją, bet ir ị reaktyviają galią. Vartotojai taip pat turi sumokèti elektros tinklams už reaktyviają energiją.

Mažos, energiją ị elektros tinklą tiekiančios fotoelektrinès ir vejo jègainès, kurių skaičius nuolat auga, taip pat gali generuoti reaktyviają galią žemos ịtampos tinkle.

Apibendrinant, galima suformuluoti šias, disertacijoje sprendžiamas, reaktyviosios galios kompensavimo žemos įtampos tinkluose problemas: reaktyviosios galios tolydaus kompensavimo problema; reaktyviosios galios asimetrinio kompensavimo problema.

Siekiant išspręsti problemą, buvo iškeltos ir patikrintos šios hipotezès: reaktyviosios galios kompensatoriai su atskirais klasikiniais ir atskirais kaskadiniais inverteriais kiek- 
vienai fazei gali kompensuoti reaktyviają galią žemos ịtampos tinkle asimetriškai; Reaktyviosios galios kompensatorius su vienfaziais reaktoriais, su oro tarpu, yra tinkamas tolydžiam asimetriniam reaktyviosios galios kompensavimui žemos įtampos tinkle.

\section{Darbo aktualumas}

Elektros energijos kokybė yra strategiškai svarbi, nes ji lemia energijos tiekimo patikimumą, efektyvumą ir saugumą. Elektros energijos gamyba, perdavimas ir naudojimas yra sudètingas procesas, kurio vienas iš neigiamų reiškinių, bloginančių elektros energijos kokybę, yra reaktyvioji galia. Ji yra neišvengiama elektros tinkluose ir yra sąlygojama apkrovų, kurios naudoja arba generuoja ne tik aktyviają, bet ir reaktyviają galią. Siekiant pagerinti elektros energijos kokybę, labai svarbu kompensuoti reaktyviają galią, todèl reaktyviosios galios kompensavimo priemonès yra vis labiau naudojamos ir nuolat tobulinamos. Dèl šios priežasties moksliniai tyrimai, skirti pažangiems reaktyviosios galios kompensatoriams, leidžiantiems efektyviai kompensuoti reaktyviają galią žemos ịtampos tinkluose, yra aktualūs ir turi praktinę vertę.

Disertacijoje pateiktų rezultatų aktualumą įrodo ir tai, kad šiuos tyrimus inicijavo ir finansavo aukštujų technologijų i̇mone, kurianti ir gaminanti reaktyviosios galios kompensatorius.

\section{Tyrimo objektas}

Disertacijos tyrimų objektas yra tolydūs asimetriniai reaktyviosios galios kompensatoriai žemos ịtampos elektros tinklui su inverteriu ir su šuntu.

\section{Darbo tikslas}

Darbo tikslas - sukurti reaktyviosios galios kompensatorius tolydžiam asimetriniam reaktyviosios galios kompensavimui žemos ịtampos elektros tinkluose.

\section{Darbo uždaviniai}

Darbo tikslui pasiekti buvo sprendžiami šie uždaviniai:

1. Patobulinti ir pritaikyti kaskadinị inverterị tolydžiam reaktyviosios galios kompensavimui žemos įtampos tinkle.

2. Sukurti kompensatorius su atskirais, klasikiniu ir kaskadiniu, inverteriais kiekvienai fazei asimetriniam reaktyviosios galios kompensavimui žemos įtampos tinkle.

3. Sukurti kompensatorių su šuntu, kuriame naudojamas tiristoriumi valdomas reaktorius, tolydžiam asimetriniam reaktyviosios galios kompensavimui žemos itampos tinkle. 


\section{Tyrimų metodika}

Darbe taikomi analitiniai metodai, modeliavimas ir eksperimentiniai tyrimai. Reaktyviosios galios kompensatorių modeliavimas atliktas Matlab/Simulink programa. Eksperimentiniai tyrimai atlikti naudojant sukurtą kompensatoriaus su šuntu tolydžiam asimetriniam reaktyviosios galios kompensavimui žemos įtampos tinkle maketą. Kompensatoriaus valdymo algoritmai ịgyvendinti ịterptinejje sistemoje, sukuriant programas FB ir IL programavimo kalbomis.

\section{Darbo mokslinis naujumas}

1. Pasiūlyta nauja tolydžiojo asimetrinio reaktyviosios galios kompensatoriaus žemos įtampos tinklui schema su kaskadiniu inverteriu.

2. Pasiūlyta nauja tolydžiojo asimetrinio kompensatoriaus, sudaryto iš atskirų klasikinių inverterių arba atskirų kaskadinių inverterių kiekvienai žemos įtampos tinklo fazei, schema.

3. Sukurtas naujas kompensatorius su šuntu, kuriame naudojamas tiristoriu valdomas reaktorius, skirtas tolydžiam, asimetriniam reaktyviosios galios kompensavimui žemos įtampos tinkle.

\section{Darbo rezultatų praktinė reikšmè}

Tyrimo rezultatai, pasiekti doktorantūros procese, buvo pritaikyti igyvendinant projektą „Bepakopio reaktyviosios galios kompensatoriaus sukūrimas“ Nr. 3400-S510, (20182019) m., kuri vykdè Valstybinio mokslinių tyrimų instituto Fizinių ir technologijos mokslų centro Elektroninių sistemų laboratorija. Projektas buvo programos J05-LVPA-K, „Intelektas“ - Bendrieji mokslo ir pramonės projektai, finansuojamos Lietuvos verslo paramos agentūros (LVPA), dalis. Projekto partneris buvo UAB „Elgama sistemos“.

\section{Ginamieji teiginiai}

1. Kaskadinio inverterio pritaikymas, naudojant du nuosekliai sujungtus inverterius, iš kurių vienas veikia tinklo dažniu, o kitas - aukštesniu dažniu, naudojant ITM metodą, leidžia sukurti kompensatorių iš tiristorių ir MOSFET tranzistorių inverterių derinio.

2. Kompensatoriai su atskirais, klasikiniu ir kaskadiniu, inverteriu kiekvienai fazei su neutrale, užtikrina asimetrinị reaktyviosios galios kompensavimą žemos itampos elektros tinkle.

3. Kompensatoriai su šuntu, kuriuose naudojamas tiristoriumi valdomas reaktorius, kurie paprastai naudojami aukštos ir vidutinès įtampos elektros tinkluose, gali būti taikomi žemos įtampos tinkle tolydžiam asimetriniam kompensavimui, naudojant vienfazius reaktorius su oro tarpu, jungiant juos žvaigžde su neutrale. 


\section{Darbo rezultatų aprobavimas}

Disertacijos tema yra atspausdinti 4 moksliniai straipsniai: 3 recenzuojamuose mokslo žurnaluose ir 1 konferencijų darbuose.

Disertacijoje atliktų tyrimų rezultatai buvo pristatyti 5 mokslinėse konferencijose:

- FizTech2015 doktorantų konferencija. Vilnius, 2015;

- FizTech2016 doktorantų konferencija. Vilnius, 2016;

- 20 Lietuvos jaunujų mokslininkų konferencija „Mokslas - Lietuvos ateitis“, Vilnius, 2017;

- 21 tarptautinè konferencija „Electronics 2017“, Palanga, 2017;

- 22 Lietuvos jaunujų mokslininkų konferencija „Mokslas - Lietuvos ateitis“, Vilnius, 2019.

\section{Disertacijos struktūra}

Disertaciją sudaro įvadas, trys skyriai ir bendrosios išvados. Darbo pabaigoje pateiktas literatūros šaltinių ir autoriaus publikacijų disertacijos tema sąrašas.

Darbo apimtis yra 93 puslapiai, neiskaitant priedų, tekste panaudota 10 numeruotų formulių, 52 paveikslai ir 3 lentelès. Rašant disertaciją buvo panaudoti 82 literatūros šaltiniai.

\section{Reaktyviosios galios kompensatorių ir jų veikimo principų apžvalga}

Šiame skyriuje apžvelgiami reaktyviosios galios kompensatorių tipai ir jų savybès. Pirmoje skyriaus dalyje analizuojami reaktyviosios galios kompensavimo būdai ir skirtingos reaktyviosios galios kompensatorių su inverteriais schemos. Antroje apžvalgos dalyje aprašomi reaktyviosios galios kompensatoriai su šuntu. Pateikiamos pirmojo skyriaus išvados ir suformuluojamos disertacijos užduotys.

Reaktyviają galią tiekia arba vartoja elektros tinklu apkrovos, kurias sudaro ne tik aktyvioji, bet ir reaktyvioji dedamosios. Reaktyvioji galia veikia kaip papildoma tinklo apkrova, kuri neatlieka naudingo darbo, todèl ją reikia kompensuoti. Reaktyviają galią sukuria induktyviosios ir talpinès apkrovos, taip pat netiesinès apkrovos. Reaktyviają galią taip pat gali generuoti prie elektros tinklo prijungtos fotoelektrinès ir vèjo jègainès, kuriu skaičius nuolat auga. Reaktyvioji galia atsiranda, kai tarp jëgainès tiekiamos ị tinklą srovès ir tinklo ịtampos yra fazès poslinkis. Reaktyvioji galia matuojama reaktyviaisiais VoltAmperais (VAR).

Didelè dalis elektros tinklų apkrovų yra induktyviojo pobūdžio, pavyzdžiui, elektros varikliai, transformatoriai, indukcinio šildymo priemonès. Todèl ịprastoje reaktyviosios galios kompensavimo sistemoje žemos įtampos elektros tinkle taikomos kondensatoriu baterijos, padalintos i pakopas, prijungtas prie elektros tinklo lygiagrečiai. Pagrindinis kompensatorių, pagrịstų kondensatorių baterijomis, trūkumas yra tai, kad kondensatoriu banko sukuriama reaktyvioji galia keičiama diskretiškai, t. y. nèra galimybès visiškai su- 
kompensuoti reaktyviosios galios. Taip pat šie kompensatoriai gali kompensuoti tik simetrines induktyviąsias apkrovas, tačiau reaktyviosios tinklo apkrovos dažnai yra asimetrinès, t. y. kiekvienoje fazèje skirtingos.

Tolydžiam reaktyviosios galios kompensavimui taikomi dviejų tipų kompensatoriai:

1. Reaktyviosios galios kompensatoriai su inverteriu.

2. Reaktyviosios galios kompensatoriai su šuntu, kuriuose naudojamas tiristoriumi valdomas reaktorius.

Reaktyviosios galios kompensatoriai, sukurti naudojant inverteri yra vadinami statiniais kompensatoriais (angl. STATCOM). Jų veikimo principas yra paremtas inverteriu, kuris veikia kaip įtampos šaltinis. Inverteriu, naudojant impulsų trukmès moduliavimo (ITM) metodą, sukuriama kintamoji įtampa, sinchronizuota su tinklo įtampa (PQCSTATCON, 2011; Yan, 2015). Priklausomai nuo įtampos amplitudès, toks kompensatorius tolydžiai kompensuoja induktyviąą arba talpuminę reaktyviają galią. Talpuminè reaktyvioji galia tiekiama, jei inverterio ịtampos amplitudè yra didesnè už elektros tinklo įtampos amplitudę. Jei inverterio teikiama įtampos amplitudè yra mažesnè nei elektros tinklo įtampos amplitude - vartojama induktyvioji reaktyvioji galia. Jei inverterio įtampos amplitudè lygi elektros tinklo ịtampos amplitudei reaktyvioji galiai nėra tiekiam ar vartojama. Reaktyviosios galios kompensatoriaisu inverteriu gali greitai reaguoti i tinklo elektros tinklo pokyčius ir visiškai sukompensuoti reaktyviosiąją galią. Pagrindinis trūkumas yra tas, kad reaktyviosios galios kompensatoriai su inverteriu negali kompensuoti asimetrinių reaktyviujų apkrovų.

Reaktyviosios galios kompensatoriai su šuntu yra paremti kondensatorių baterijos naudojimu, kuri yra skirta diskrečiam reaktyviosios galios parinkimui ir tiristoriu valdomu reaktoriumi - tolydžiam reaktyviosios galios priderinimui. Tiristoriu valdomu reaktorimi vartojama reaktyvioji galia valdoma keičiant reaktoriaus prijungimo prie tinklo kiekvieno įtampos pusperiodžio metu trukmę. Reaktyviosios galios kompensatoriai su šuntu yra pigesni, palyginti su kompensatoriais su inverteriais be to, jie gali kompensuoti asimetrines apkrovas, tačiau tokie kompensatoriai yra sukurti tik aukštos ir vidutinès itampos elektros tinklams. (Dixon et al., 2005; Gayatri et al., 2018; D. I. Panfilov \& ElGebaly, 2016; Sethi et al., 2014).

Energijos perdavimo schema tarp inverterio ir tinklo yra sudarytą iš dviejų įtampos šaltinių, iš kurių vienas tiekia energiją, kitas ją vartoja. İtampos šaltiniai negali būti jungiami tiesiogiai, todèl jungiami per induktyvumą. Supaprastinta perdavimo schema pateikta S1.1 paveiksle.

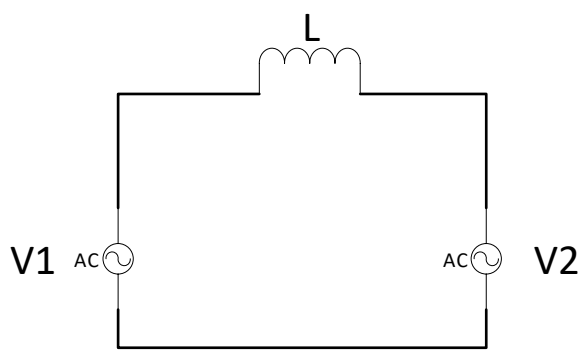

S1.1 pav. Supaprastinta energijos perdavimo tarp dviejų įtampos šaltinių schema 
I tinklą tiekiamą energiją galima valdyti dviem būdais: keičiant inverterio įtampos amplitudę, arba keičiant ịtampos fazės kampą tarp įtampų $\delta$. Aktyviosios galios $(P)$ ir reaktyviosios galios $(Q)$ vertes apskaičiuojamos naudojant formulę (Haykin \& Van Veen, 2003; Rozanov et al., 2016):

$$
P=\frac{V_{1} V_{2} \sin \delta}{X}, Q=\frac{V_{1} V_{2} \cos \delta-V_{2}^{2}}{X} .
$$

Galima pastebėti, kad $P$ ir $Q$ yra tarpusavyje susijusios. Tačiau tam tikromis aplinkybèmis jos gali būti atsietos. Darant prielaidą, kad $\delta$ yra labai mažas (abiejų ịtampų fazès praktiškai sutampa), tuomet gauname:

$$
\begin{aligned}
& \sin \delta \approx \delta, \text { kai } \delta \rightarrow 0 ; \\
& \cos \delta \approx 1, \text { kai } \delta \rightarrow 0 .
\end{aligned}
$$

Istačius gautas reikšmes i (1.1), gaunamos naujos $P$ ir $Q$ išraiškos:

$$
\begin{gathered}
P \approx \frac{V_{1} V_{2} \delta}{X}, \text { kai } \delta \rightarrow 0 ; \\
Q \approx \frac{V_{1} V_{2}-V_{1}^{2}}{X}, \text { kai } \delta \rightarrow 0 .
\end{gathered}
$$

Iš (1.3) matyti, kad reaktyvioji galia priklauso nuo išèjimo ịtampos amplitudès. Kai $V_{1}>V_{2}$, reaktyvioji galia $Q<0$, jei $V_{1}<V_{2}$, reaktyvioji galia $Q>0$, t.y., priklausomai nuo reaktyviosios galios kompensatoriaus inverterio ịtampos amplitudès, kompensatorius veikia kaip talpumine, arba kaip induktyvioji apkrova. Akivaizdu, $\operatorname{kad} P \approx 0$, kai $\delta$ labai mažas, todèl inverteris gali kompensuoti reaktyviają galią su mažais aktyviosios galios nuostoliais.

Reaktyviosios galios kompensatoriai su šuntu užtikrina tolydų reaktyviosios galios kompensavimą ir yra naudojami aukštos ir vidutinès ịtampos elektros tinkle. Kompensatorius su šuntu sudaro šie elementai: tiristoriumi jungiamas kondensatorius ir tiristoriu valdoms reaktorius, kurie yra jungiami lygiagrečiai (S1.2 pav.).

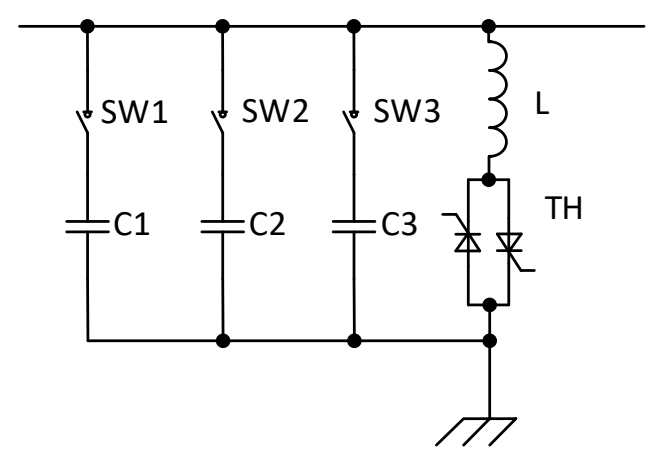

S1.2 pav. Reaktyviosios galios kompensatorius su šuntu elektrinė schema

Šis metodas suteikia galimybę vartoti reaktyviają elektros tinklo galią tiristoriu valdomu reaktoriumi, o ją tiekti tiristoriu jungiamu kondensatoriumi. Tiristoriu ijungiamas 
kondensatorius turètų būti jungiamas tinklo įtampai kertant nulinę vertę - taip sumažnama komutavimo srove ir išvengiama trikdžių. Tiristorius išsijungia automatiškai, kai tiristoriaus srovė nukrenta žemiau atidarymo srovès vertès.

Tiristoriu valdomo reaktoriaus induktyvumas keičiamas tiristoriaus atidarymo laiko momentą (atidarymo fazès kampą) (angl. firing angle).

Iš literatūros apžvalgos matyti, kad reaktyviosios galios kompensatoriai su šuntu, tik simetriniam reaktyviosios galios kompensavimui ir yra praktiškai taikomi tik aukštos ir vidutine įtampos tinkluose. (Acha, 2002; Čerňan \& Tlustý, 2015; Chang \& Liao, 2017; Dixon et al., 2005; Farkoush et al., 2016; Fuchs \& Masoum, 2011; Hong Hu et al., 2015; Igbinovia et al., 2015; Ilisiu \& Dinu, 2019; Liberado et al., 2013; Liu et al., 2016; Mathur \& Varma, 2002; Padiyar, 2007; D. I. Panfilov et al., 2017a, 2017b; Dmitry I. Panfilov et al., 2019; Rahmani et al., 2014; Tehrani et al., 2011; Tokiwa et al., 2017).

Remiantis disertacijoje atlikta reaktyviosios galios kompensatorių ir jų veikimo principų apžvalga, suformuluotas disertacijos tikslas ir sprendžiami uždaviniai.

\section{Asimetriniai reaktyviosios galios kompensatoriai su inverteriu}

Šiame skyriuje aprašomas reaktyviosios galios kompensatorius, sukurtas naudojant kaskadinị inverterị, kuriame panaudota tiristorinio ir tranzistorinio inverterių kombinacija. Taip pat pateikiami siūlomi kompensatoriai asimetriniam reaktyviosios galios kompensavimui su atskirais kiekvienai fazei klasikiniu arba kaskadiniu inverteriais. Gauti rezultatai paskelbti dviejuose publikacijose (Šapurov, Dervinis, et al., 2020; Sapurov et al., 2017).

Kaskadiniai inverteriai yra plačiai naudojami variklių pavarose. Šiame darbe kaskadinị inverterị siūloma taikyti reaktyviosios galios kompensavimui. Kaskadinio inverterio išejjimo įtampa formuojama naudojant du nuosekliai sujungtus inverterius (S2.1 pav.). Pirmasis inverteris veikia tinklo įtampos dažniu, t. y. žemu perjungimo dažniu, o antrsis aukštu dažniu. Pirmojo inverterio suformuotos stačiakampio impulso formos ịtampos spektras turi ne tik pirmają bet ir aukštesniąsias harmonikas. Antrasis inverteris, veikiantis aukštu dažniu, naudojant ITM metodą, naudojant sudarytą inverterio raktų valdymo algoritmą, formuoja įtampą kurios spektre esančios harmonikos eliminuoja aukštesniąsias harmonikas iš pirmojo inverterio formuojamos įtampos spektro. Tokiu būdu suformuojama sinuso formos kompensatoriaus įtampa. Reikalinga aukštesniujų dažnių harmoninikų amplitudè yra žymiai mažesnè už pagrindinès harmonikos amplitudę, todėl antrasis inverteris gali būti maitinamas santykinai žema įtampa. Tuo tarpu pirmasis inveteris turi būti maitinamas aukštesne įtampa, kuri atitinka elektros tinklo įtampos amplitudę. Kadangi pirmojo inverterio raktų komutavimo dažnis yra žemas, tradiciškai inverteriuose naudojamus IGBT tranzistorių raktus galima pakeisti tiristoriniais raktais, kurių atviro rakto varža yra žymiai mažesnė už IGBT tranzistorių. Antrajai pakopai gali būti naudojami žemos ittampos aukšto dažnio MOSFET tranzistoriai, pasižymintys maža atviro tranzistoriaus varža ir mažais perjungimo nuostoliais. Tokiu būdu sukurtas kompensatorius pasižymi mažesniais galios nuostoliais, lyginant su klasikiniu, realizuotu naudojant IGBT tranzistorius.

Kuriant kompensatorių, buvo tiriamas pirmojo inverterio generuojamo stačiakampio įtampos impulso ir jo srovès spektras. Rezultatai pateikti S2.2 paveiksle. 


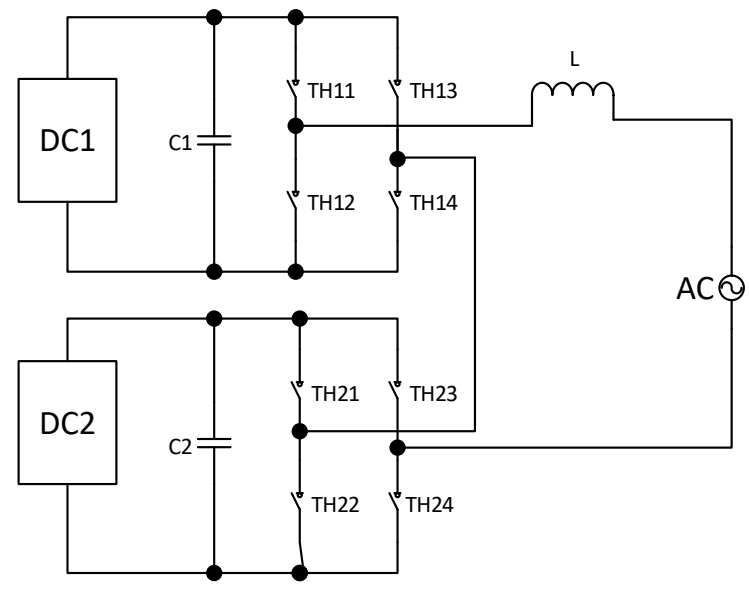

S2.1 pav. Struktūrinè kaskadinio inverterio schema

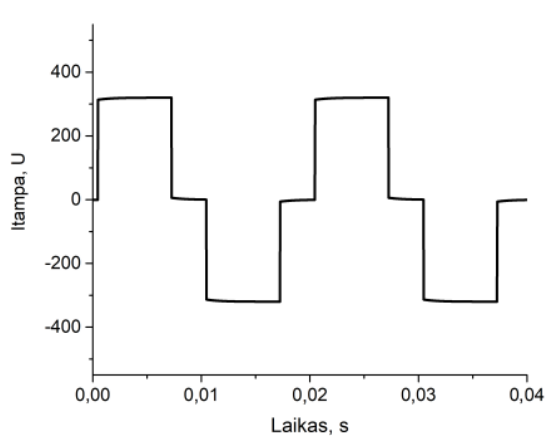

a)

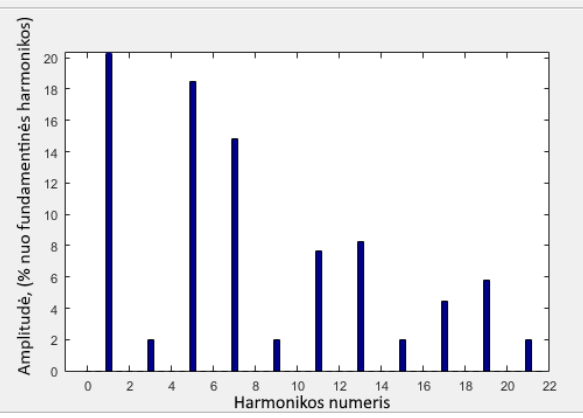

c)

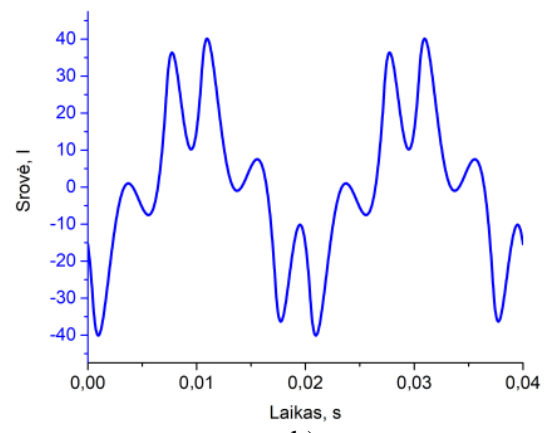

b)

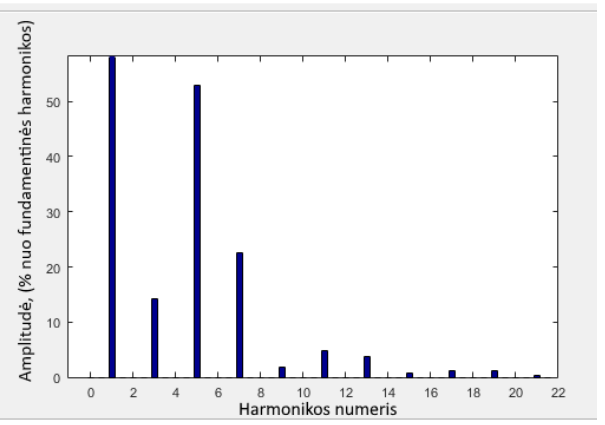

d)

S2.2 pav. Inverterio išèjimo įtampa srovè ir jų spektrai netaikant harmonikų eliminavimo:

a) srové; b) įtampa; c)ittampos spektras; d) srovès spektras 
Tiriamasis kompensatorius su kaskadiniu inverteriu gali kompensuoti talpinę ir induktyviają reaktyviają galią iki $Q=4 \mathrm{kVAr}$. Elektros tinklo įtampa ir srovè bei srovès spektras pateikiami S2.4 paveiksle. Matome, kad S2.4 pav. a) maitinimo srovė yra talpuminè, o S2.4 pav. b) induktyvioji. Srovès netiesiniai iškraipymai, kai reaktyviosios galios kompensatorius veikia kaip talpuminè apkrova, yra didesni, palyginti su tuo atveju, kai jis veikia kaip induktyvioji apkrova (atitinkamai 4,9\% ir 1,7\%).

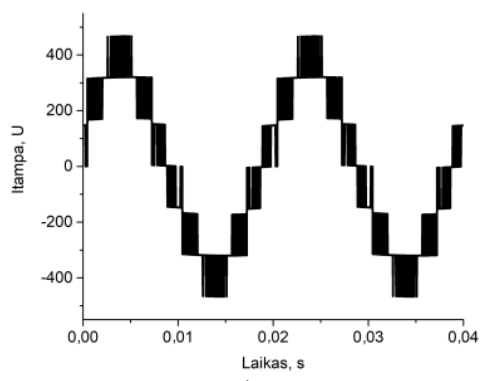

a)

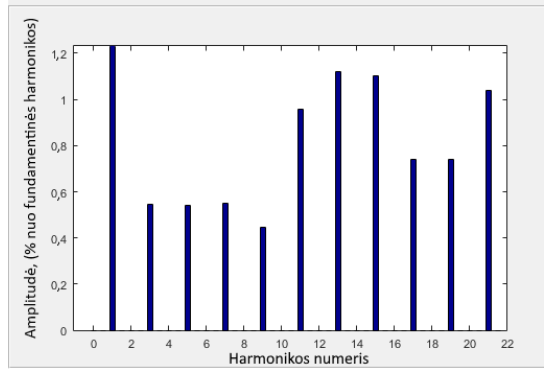

c)

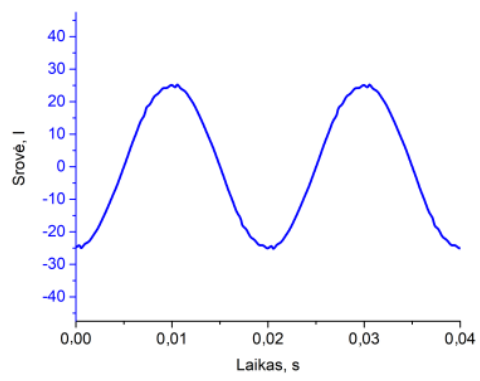

b)

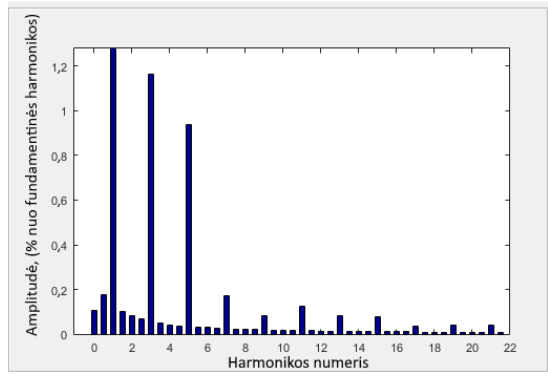

d)

S2.3 pav. Inverterio išèjimo įtampa srovè ir jų spektrai taikant harmonikų eliminavimą iki 22-osios harmonikos: a) srove; b) įtampa; c) įtampos spektras; d) srovės spektras

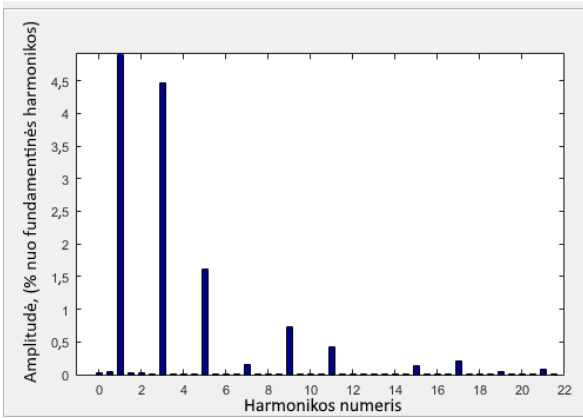

a)

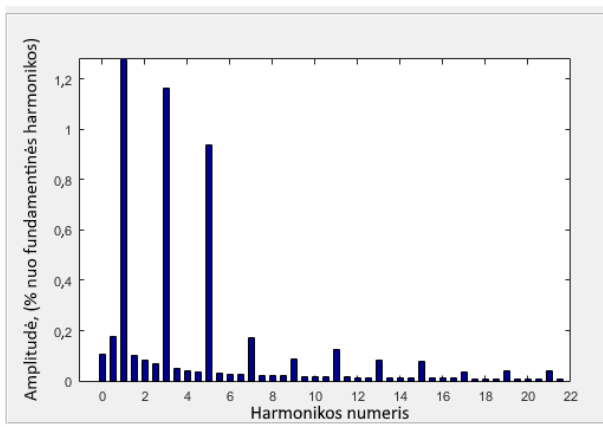

b)

S2.4 pav. Kompensatoriaus srovès spektras su harmonikų eliminavimu iki 22-osios harmonikos: a) kai kompensatorius veikia kaip induktyvioji apkrova b) kai kompensatorius veikia kaip tapluminè apkrova 


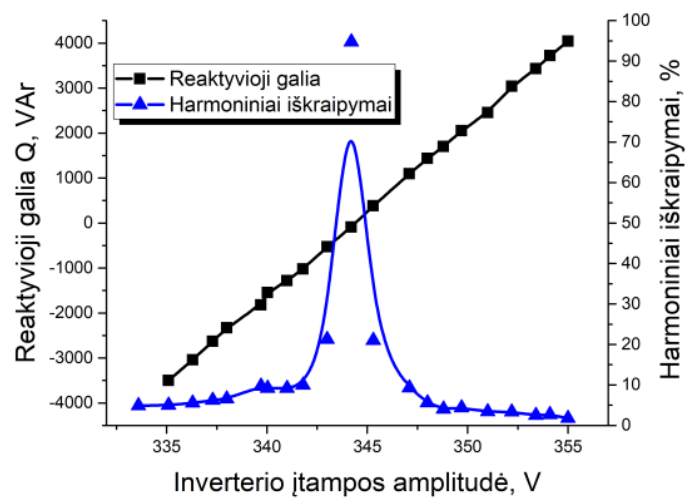

S2.5 pav. Reaktyviosios galios ir netiesinių iškraipymų priklausomybès nuo inverterio išèjimo įtampos amplitudès su harmonikų eliminavimu iki 22-osios harmonikos

Ryšys tarp kompensatoriaus vartojamos ar tiekiamos reaktyviosios galios ir netiesinių iškraipymų yra pateikiamas S2.5 paveiksle. Kompensatoriaus vartojamos ar tiekiamos reaktyviosios galios vertė kinta keičiant kompensatoriaus išèjimo įtampos amplitudę. Galima pastebėti, kad didžiausia harmoninių iškraipymų vertė yra pasiekiama, kai kompensatoriaus tiekiama reaktyvioji galia yra minimali. Iškraipymai mažèja, kai padidèja absoliuti reaktyviosios galios verte.

Asimetriniai trijų fazių kompensatoriai su atskirais inverteriais kiekvienai fazei. Pasiūlytos dvi kompensatorių schemos: kompensatoriai su atskirais klasikiniais inverteriais kiekvienai fazei ir kompensatoriai su atskirais kaskadiniais inverteriais kiekvienai fazei.

Klasikinis inverteris yra plačiai taikomas galios elektronikoje, taip pat ir reaktyviosios galios kompensatoriuose (Neves et al., 2009; Rozanov et al., 2016). Nepaisant to, asimetriniai reaktyviosios galios kompensatoriai su atskirais klasikiniais inverteriais kiekvienai fazei nèra gaminami. Siūlomo asimetrinio reaktyviosios galios kompensatoriaus su atskirais klasikiniais inverteriais kiekvienai fazei schema yra pateikiama S2.6 paveiksle. Šis kompensatorius sudarytas iš trijų nepriklausomų vienfazių klasikinių inverterių, sujungtų žvaigžde su neutrale.

Kitas siūlomas kompensatorius sudarytas iš atskirų kiekvienai fazei kaskadinių inverterių. Kiekviena kaskadinio inverterio pakopa maitinama izoliuotu įtampos šaltiniu. Toks inverteris tiekia septynių lygių išèjimo įtampą. Norint sumažinti perjungimo nuostolius, didžioji dalis galios sukuriama pirmajame inverteryje veikiančioje žemu dažniu, o antrsis inverteris eliminuoja mažesnès galios harmonikas, veikdamas santykinai aukštu dažniu. Asimetrinio reaktyviosios galios kompensatoriaus su atskirais kaskadiniais inverteriais kiekvienai fazei schema pateikta S2.7 paveiksle. 


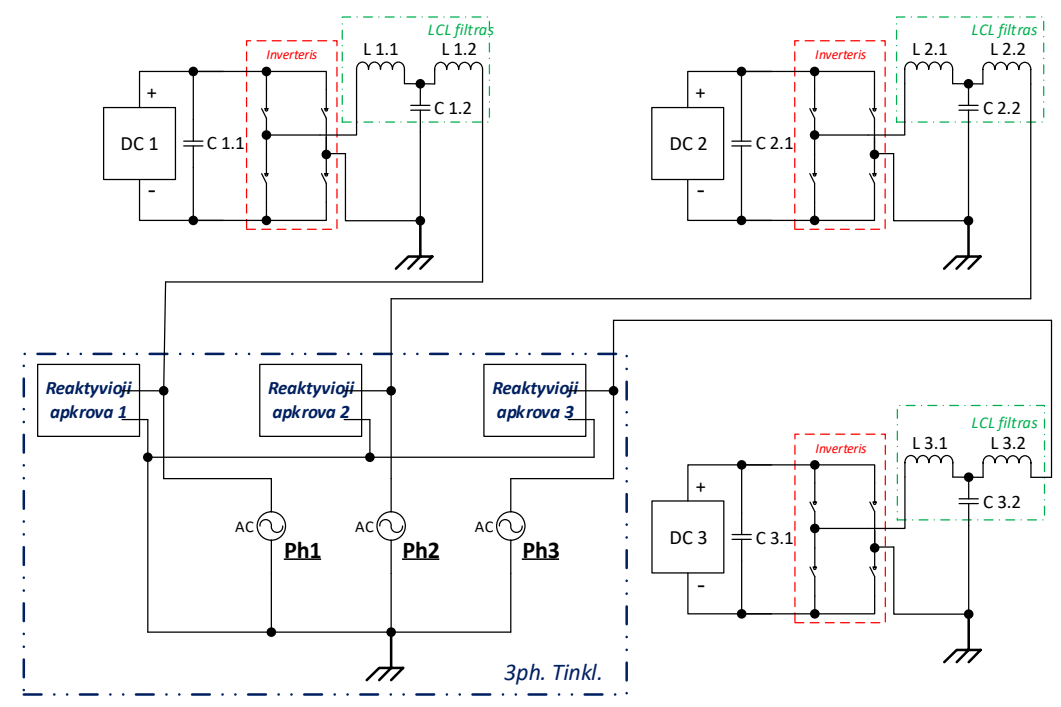

S2.6 pav. Struktūrinè trifazio kompensatoriaus su atskirais klasikiniais inverteriais kiekvienai fazei schema

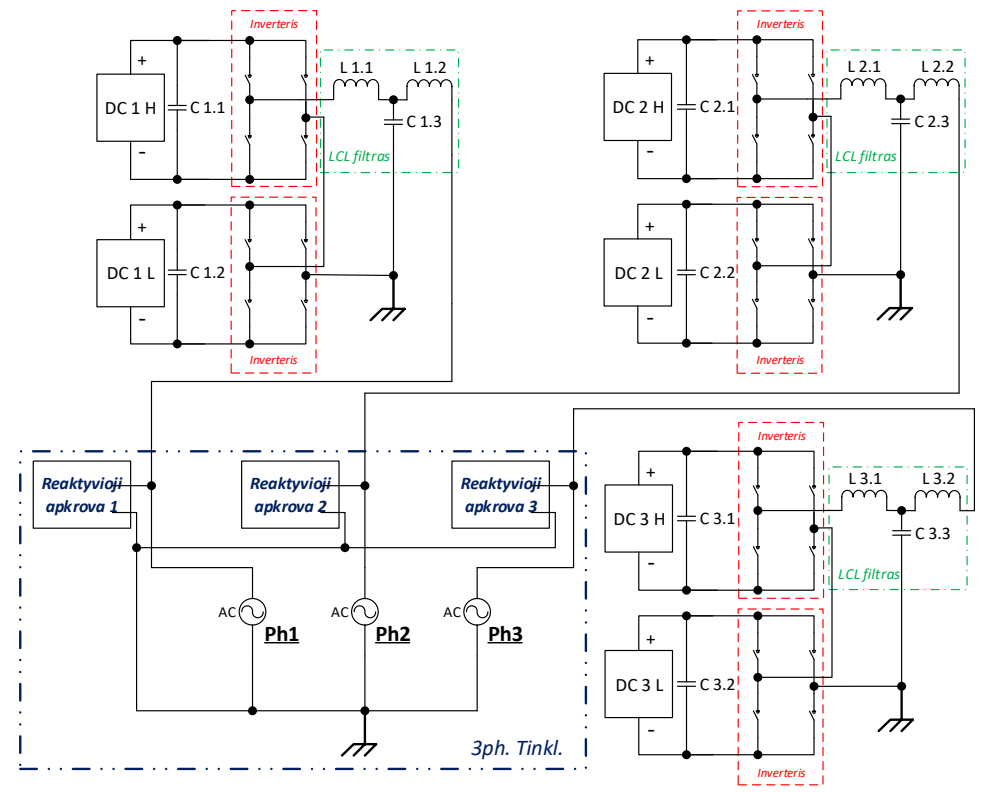

S2.7 pav. Struktūrinè trifazio kompensatoriaus su atskirais kaskadiniais inverteriais kiekvienai fazei schema 
Asimetriniai reaktyviosios galios kompensatoriai su atskirais inverteriais kiekvienai fazei buvo ištirti modeliuojant. Pradiniu momentu kompensatoriai yra išjungti, elektros tinkle nèra reaktyviujų apkrovų. Vèliau kiekvienai fazei po vieną prijungiamos skirtingos reaktyviosios apkrovos: -4,4 kVAr pirmajai fazei; 2,0 kVAr antrajai fazei; 3,0 kVAr trečiajai fazei. Kompensatorius sureguliuotas taip, kad reaktyviosios galios kompensavimas kiekvienoje fazèje prasidètų praejjus $0,04 \mathrm{~s}$ po reaktyviosios apkrovos prijungimo. Pereinamieji abiejų procesai abiejų tipų kompensatoriams pateikiami S2.8 paveiksle.

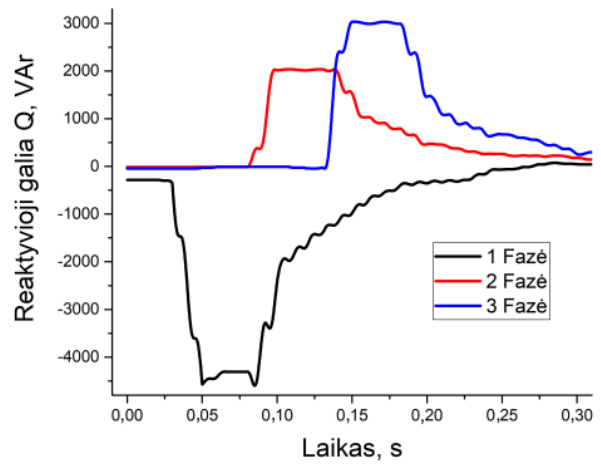

a)

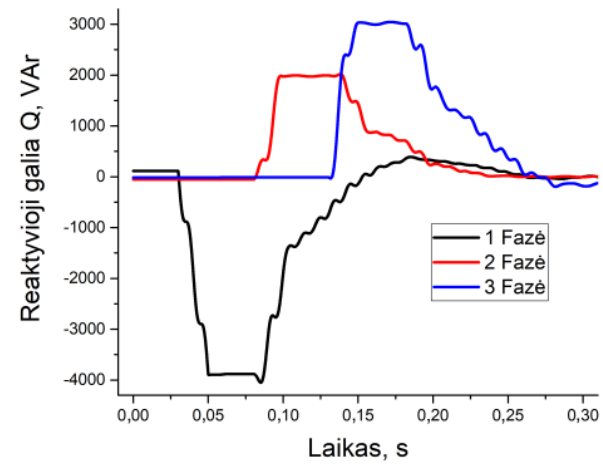

b)

S2.8 pav. Pereinamieji reaktyviosios galios procesai: a) kai taikomas kompensatorius su atskirais klasikiniais inverteriais kiekvienai fazei; b) kai taikomas kompensatorius su atskirais kaskadiniais inverteriais kiekvienai fazei

Paveiksle matyti, kad reaktyviosios galios kompensavimas bet kurioje fazèje neturi jokios itakos reaktyviosios galios kompensavimui kitose fazèse. Pereinamojo proceso trukmė, per kuri visiškai sukompensuojama reaktyvioji galia, yra 0,12-0,22 s. Kadangi kompensuojama kiekvienoje fazèje reaktyvioji galia skiriasi, galima daryti išvadą, kad abu pasiūlyti asimetriniai reaktyviosios galios kompensatoriai su atskirais inverteriais kiekvienai fazei yra tinkami asimetriniam reaktyviosios galios kompensavimui.

\section{Asimetriniai reaktyviosios galios kompensatoriai su šuntu}

Šiame skyriuje pateikiami tolydžiujų asimetrinių reaktyviosios galios kompensatorių su šuntu žemos įtampos tinklui, tyrimo rezultatai. Siūlomas kompensatorius buvo tiriamas eksperimentiškai, naudojant pagamintą tyrimų maketą. Gauti rezultatai paskelbti dviejuose publikacijose (Šapurov, Bielskis, et al., 2020; Šapurov, Bleizgys, et al., 2020).

Tyrimų maketo, skirto ištirti sukurtą asimetrinị reaktyviosios galios kompensatorių su šuntu struktūrinè schema pateikiama S3.1 paveiksle.

Tyrimų maketo schemą sudaro trifazis maitinimo šaltinis $(|U|=230 \mathrm{~V}, f=$ $50 \mathrm{~Hz}$ ); komutaciniai jungikliai SW1 - SW3; nulio aptikimo grandinès kiekvienai fazei; tiristoriniai jungikliai T1 - T3 kiekvienai fazei; valdymo blokas. Maketas skirtas reaktyviosios galios kompensatorių su šuntu, naudojant trifazį reaktorių su bendra šerdimi su oro tarpu ir naudojant atskirus reaktorius su šerdimi su oro tarpu kiekvienai fazei, tyrimui. 
Buvo suprojektuoti ir pagaminti trifazis reaktorius su bendra šerdimi (L1) sujungtas žvaigžde su neutrale ir trys atskiri vienfaziai reaktoriai su šerdimis su oro tarpu (L2 - L4), sujungti žvaigžde su neutrale. Tyrimų maketas pateikiamas S3.2 paveiksle.

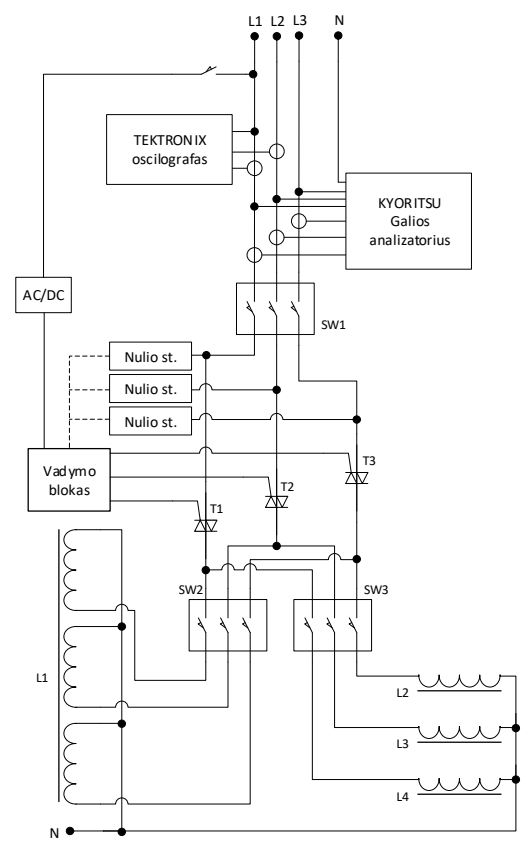

S3.1 pav. Asimetrinių reaktyviosios galios kompensatorių su šuntu tyrimų maketo struktūrinè schema

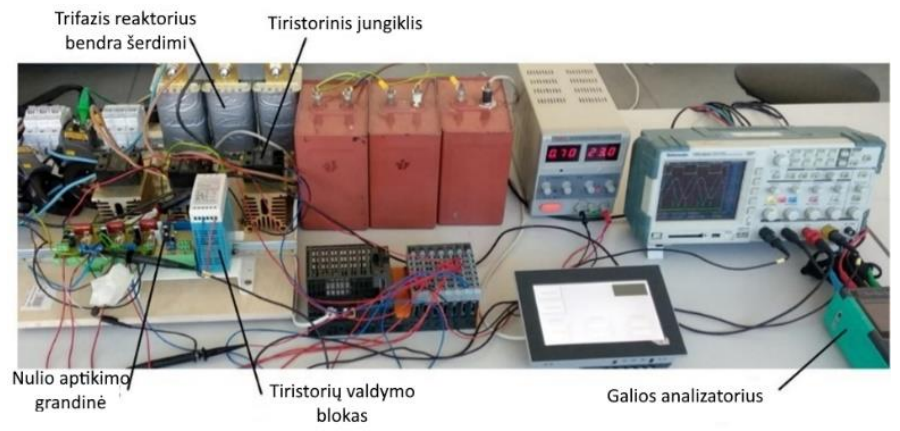

S3.2 pav. Asimetrinių reaktyviosios galios kompensatorių su šuntu tyrimų maketas

Matuojant tinklo įtampą ir srovę bei reaktyviają ir aktyviają galias buvo naudojamas galios analizatorius ir oscilografas. Tyrimai atlikti žemos įtampos tinkle su simetrinėmis ir asimetrinèmis reaktyviosiomis fazių apkrovomis. Trikampių jungti reaktoriai ir 
žvaigžde jungti reaktoriai be neutralès nebuvo tiriami, nes esant šiam jungimo būdui neasimetrinis reaktyviosios galios kompensavimas neịmanomas.

Tyrimams suprojektuotas ir pagamintas vienfazis reaktorius, šerdimi su oro tarpu gali kompensuoti $Q=4,2 \mathrm{kVAr}$ reaktyviąą galią, kurią žemosios įtampos tinkle $|U|=230 \mathrm{~V}$ atitinka fazinè srovè, kurios efektinè vertè yra $I=18,5 \mathrm{~A}$. Bendra visų trijų reaktorių kompensuojama reaktyvioji galia yra $Q=12,6 \mathrm{kVAr}$. Reaktoriaus pilnutinè varža $|Z|=$ $\frac{|U|}{|I|} \approx 12,5 \Omega$, o induktyvumas $L=\frac{X_{L}}{\omega} \approx 40 \mathrm{mH}$. Reaktoriaus induktyvumas buvo derinamas keičiant šerdies oro tarpo ploti.

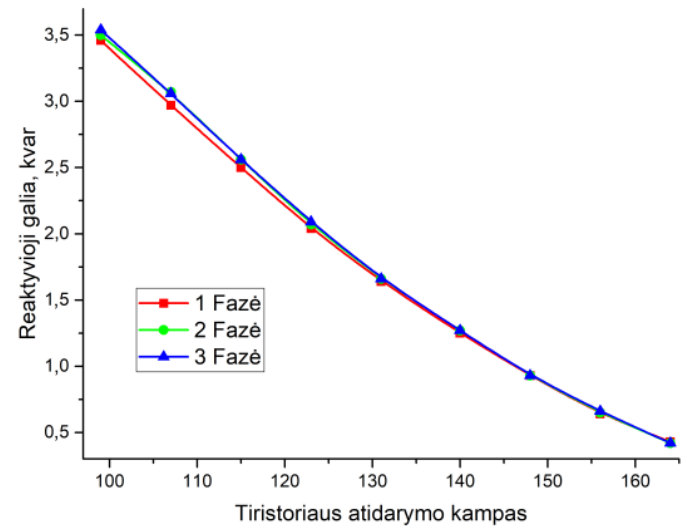

S3.4 pav. Reaktoriaus su šuntu kompensuojamos reaktyviosios galios priklausomybė nuo tiristorių atidarymo kampo

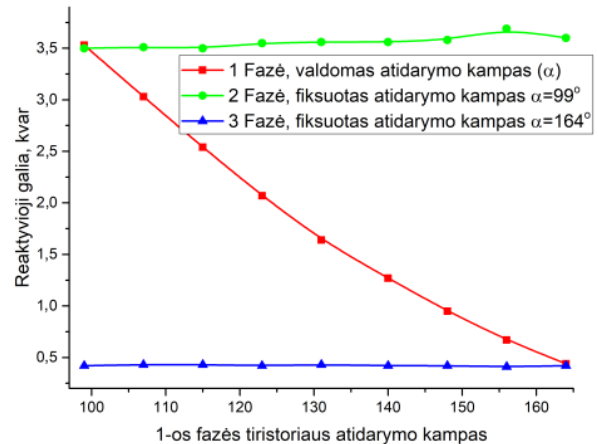

a)

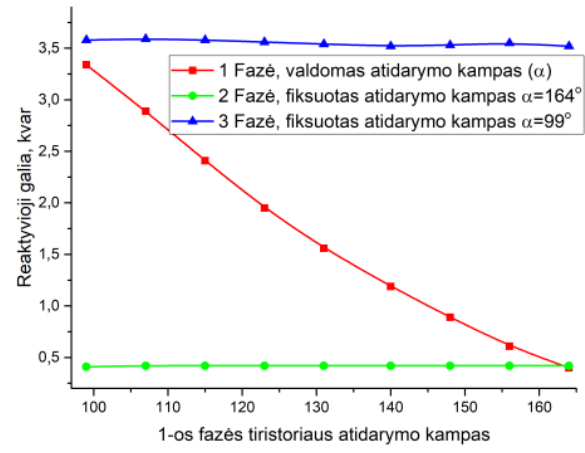

b)

S3.5 pav. Sukurto kompensatoriaus su šuntu kompensuojamos reaktyviosios galios priklausomybė nuo tiristoriaus atidarymo fazès kampo, kai dviejų fazių tiristorių atidarymo kampai yra pastovūs, o vienos fazes tiristoriaus atidarymo kampas keičiamas

Kompensatorius su šuntu, kuriame naudojami trys atskiri reaktoriai kiekvienai fazei buvo ištirtas eksperimentiškai. Visų pirma buvo tiriama reaktyvioji priklausomybe nuo 
tiristorių atidarymo fazės kampo, kai visų fazių tiristorių atidarymo kampai vienodi (simetrinis reaktyviosios galios kompensavimas). Tyrimų rezultatai pateikiami S3.4 paveiksle. Kitas eksperimentas buvo atliktas, kai vienos fazès tiristoriaus atidarymo kampas keičiamas, o kitų dviejų fazių tiristorių atidarymo kampai fiksuoti ties $165^{\circ}$ ir $99^{\circ}$ (S3.5 paveikslas). Matyti, kad vienos fazès kuriama reaktyvioji galia neturi įtakos kitų fazių reaktyviajai galai. Todèl galima teigti, kad: trijų vienfazių reaktorių panaudojimas leidžia nepriklausomai valdyti kiekvienos fazès reaktyviają galią, o kompensatorius su trimis vienfaziais reaktoriais yra tinkamas tolydžiam asimetriniam reaktyviosios galios kompensavimui žemos įtampos tinkle.

\section{Bendrosios išvados}

1. Kaskadinis inverteris sudarytas iš dviejų nuosekliai sujungtų inverterių, iš kurių vienas veikia $50 \mathrm{~Hz}$ dažniu, o kitas $-8 \mathrm{kHz}$ dažniu, taikant impulso trukmès moduliaciją, leidžia sukurti kompensatorių naudojant tiristorinių ir MOSFET raktų derinị.

2. Atskirų inverterių kiekvienai fazei kompensatoriai, igyvendinti taikant klasikinị ir kaskadinị inverterius su prijungta neutrale, leidžia reaktyviąją galią žemos itampos elektros tinkle kompensuoti asimetriškai.

3. Kompensatoriai su šuntu, kuriuose naudojamas tiristoriu valdomas reaktorius, kurie paprastai naudojami aukštos ir vidutinès įtampos elektros tinkluose, gali būti įdiegti žemos įtampos tinkle tolydžiam asimetriniam kompensavimui, naudojant vienfazius reaktorius su oro tarpu, jungiant juos žvaigžde su neutrale.

4. Taikant kompensatoriuje su šuntu trifazi reaktorių su bendra šerdimi, keičiant vienos fazès tiristoriaus atidarymo kampą nuo $90^{\circ}$ iki $180^{\circ}$, kinta ne tik kontroliuojamos fazès, bet ir kitų fazių reaktyvioji galia. Tai įrodo, kad neįmanoma valdyti reaktyviosios galios kiekvienoje fazèje atskirai, naudojant tiristoriumi valdomą reaktorių su bendra šerdimi, t. y., kompensatorius su tokiu reaktoriumi nèra tinkamas asimetriniam reaktyviosios galios kompensavimui.

5. Sukurtas reaktyviosios galios kompensatorius su trimis vienfaziais reaktoriais leidžia valdyti reaktyviają galią iki $4 \mathrm{kVAr}$ su 0,955-0,975 naudingumo koeficientu kiekvienoje fazejje nepriklausomai. Tai ịrodo, kad trijų vienfazių reaktorių pagrindu sukurtas kompensatorius yra tinkamas tolydžiam asimetriniam reaktyviosios galios kompensavimui žemos įtampos tinkle. 



\section{Annexes $^{1}$}

Annex A. Declaration of Academic Integrity

Annex B. The Co-authors' Agreements to Present publications for the Dissertation Defence

Annex C. Copies of Scientific Publications by the Author on the Topic of the Dissertation

\footnotetext{
${ }^{1}$ The annexes are supplied in the enclosed compact disc.
} 


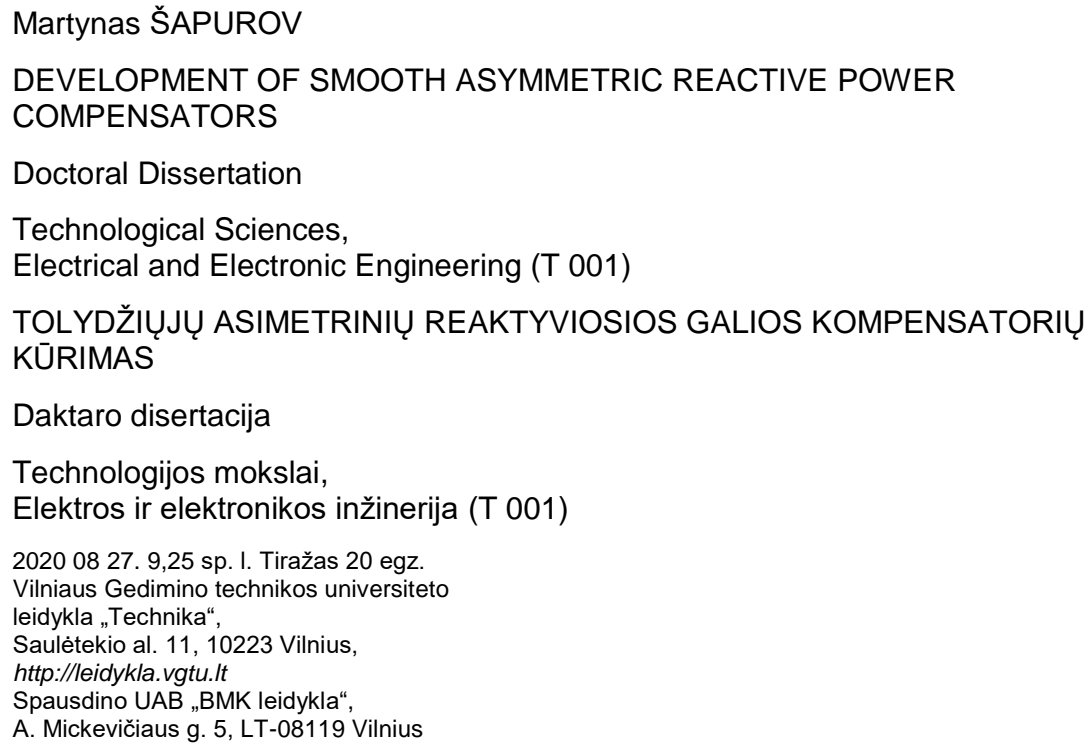

